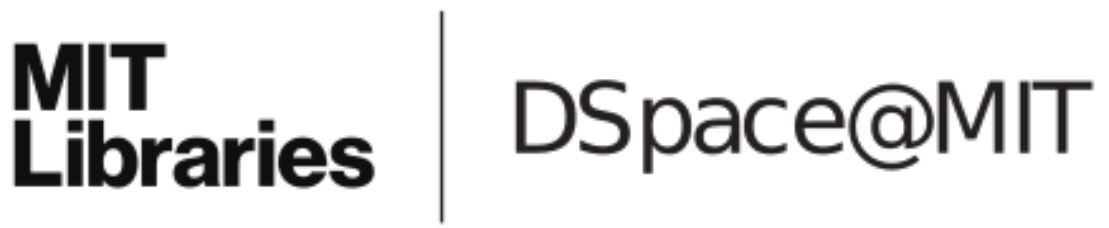

\author{
MIT Open Access Articles
}

\section{Modeling Alzheimer's disease with human induced pluripotent stem (iPS) cells}

The MIT Faculty has made this article openly available. Please share how this access benefits you. Your story matters.

Citation: Mungenast, Alison E. et al. “Modeling Alzheimer's Disease with Human Induced Pluripotent Stem (iPS) Cells." Molecular and Cellular Neuroscience 73 (June 2016): 13-31 (C) 2015 Elsevier Inc

As Published: http://dx.doi.org/10.1016/J.MCN.2015.11.010

Publisher: Elsevier

Persistent URL: http://hdl.handle.net/1721.1/112682

Version: Author's final manuscript: final author's manuscript post peer review, without publisher's formatting or copy editing

Terms of use: Creative Commons Attribution-NonCommercial-NoDerivs License 


\section{Modeling Alzheimer's disease with human induced pluripotent stem (iPS) cells}

Article in Molecular and Cellular Neuroscience · December 2015

DOI: $10.1016 /$ j.mcn.2015.11.010

CITATIONS

15

3 authors, including:

\section{Alison Mungenast}

Eisai AiM Institute, Eisai Inc.

45 PUBLICATIONS 1,563 CITATIONS

SEE PROFILE
Sandra Siegert

IST Austria

17 PUBLICATIONS 907 CITATIONS

SEE PROFILE 


\title{
Modeling Alzheimer's disease with human induced pluripotent stem (iPS) cells
}

\author{
Alison E. Mungenast ${ }^{1}$, Sandra Siegert ${ }^{*}, 1$, Li-Huei Tsai \\ Picower Institute for Learning and Memory, Massachusetts Institute of Technology (MIT), Cambridge, MA, USA
} Department of Brain and Cognitive Sciences, MIT, Cambridge, MA, USA

\section{A R T I C L E I N F O}

\section{Article history:}

Received 10 July 2015

Revised 5 November 2015

Accepted 25 November 2015

Available online $\mathrm{xxxx}$

\section{Keywords:}

Induced pluripotent stem (iPS) cells

Alzheimer's disease

Neurons

Glia

Stem cell models

Neurodegeneration

Three-dimensional culture

In vitro models

Disease modeling

Translational research

\begin{abstract}
A B S T R A C T
In the last decade, induced pluripotent stem (iPS) cells have revolutionized the utility of human in vitro models of neurological disease. The iPS-derived and differentiated cells allow researchers to study the impact of a distinct cell type in health and disease as well as performing therapeutic drug screens on a human genetic background. In particular, clinical trials for Alzheimer's disease (AD) have been failing. Two of the potential reasons are first, the species gap involved in proceeding from initial discoveries in rodent models to human studies, and second, an unsatisfying patient stratification, meaning subgrouping patients based on the disease severity due to the lack of phenotypic and genetic markers. iPS cells overcome this obstacles and will improve our understanding of disease subtypes in AD. They allow researchers conducting in depth characterization of neural cells from both familial and sporadic AD patients as well as preclinical screens on human cells.

In this review, we briefly outline the status quo of iPS cell research in neurological diseases along with the general advantages and pitfalls of these models. We summarize how genome-editing techniques such as CRISPR/Cas9 will allow researchers to reduce the problem of genomic variability inherent to human studies, followed by recent iPS cell studies relevant to AD. We then focus on current techniques for the differentiation of iPS cells into neural cell types that are relevant to AD research. Finally, we discuss how the generation of three-dimensional cell culture systems will be important for understanding AD phenotypes in a complex cellular milieu, and how both two- and three-dimensional iPS cell models can provide platforms for drug discovery and translational studies into the treatment of $\mathrm{AD}$.
\end{abstract}

\section{Contents}

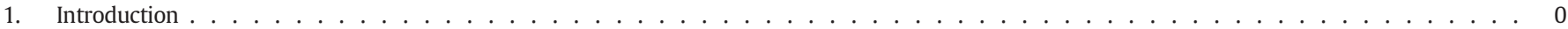

2. Human induced pluripotent stem (iPS) cells. . . . . . . . . . . . . . . . . . . . . . . . . . . . . . . . . . . . . . . . . . . 0

3. Advantages to modeling neurological disease with iPS cells . . . . . . . . . . . . . . . . . . . . . . . . . . . . . . 0

4. Drawbacks of iPS cells in neurological disease modeling . . . . . . . . . . . . . . . . . . . . . . . . . . . . . . . . . 0

5. Creating isogenic iPS cell lines as a strategy to overcome variability in human genomes . . . . . . . . . . . . . . . . . . . . . . . . 0

6. iPS cells as a model for understanding AD onset and disease progression . . . . . . . . . . . . . . . . . . . . . . . . . . . . . . 0

6.1. Phenotypic characterization of iPS cell AD models . . . . . . . . . . . . . . . . . . . . . . . . . . . . . . . . 0

6.2. AD phenotypes in Down syndrome iPS cells . . . . . . . . . . . . . . . . . . . . . . . . . . 0

7. Disadvantages in modeling $\mathrm{AD}$ with $\mathrm{iPS}$ cells $\ldots \ldots \ldots \ldots \ldots$

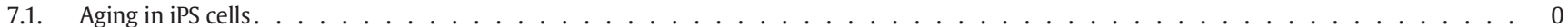

7.2. Neuronal maturation . . . . . . . . . . . . . . . . . . . . . . . . . . . . . . . . 0

7.3. Culture heterogeneity and disease phenotypes . . . . . . . . . . . . . . . . . . . . . . . . . 0

8. Differentiation of iPS cells to study cell type-specific impact toward neurological diseases . . . . . . . . . . . . . . . . . . . . . . . . . 0

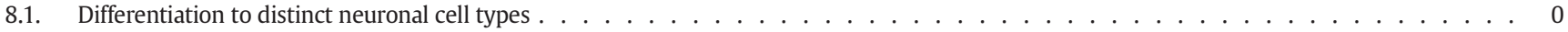

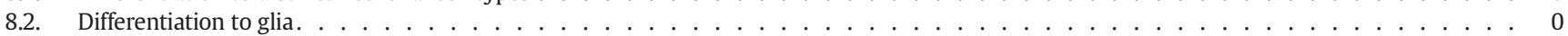

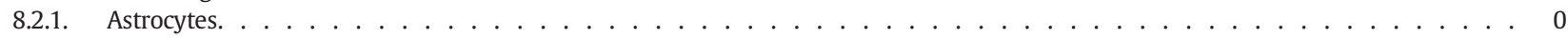

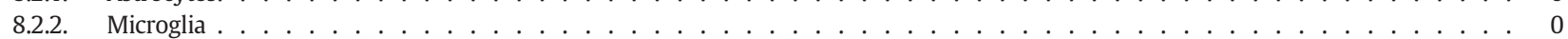

\footnotetext{
* Corresponding author at: Institute of Science and Technology Austria (IST Austria), Klosterneuburg, Austria.

E-mail address: ssiegert@ist.ac.at (S. Siegert).

1 Contributed equally.
} 
8.2.3. Oligodendrocytes.

8.3. Future challenges for cell type differentiation

9. Modeling neurological disease in three-dimensional culture systems . . . . . . . . . . . . . . . . . . . . . . . . . . . 0

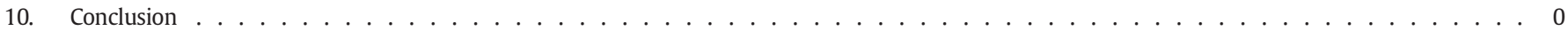

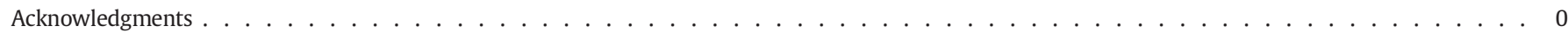

References.

\section{Introduction}

Alzheimer's disease (AD) is an age-related neurodegenerative disorder associated with severe memory impairments and has become the 6th leading cause of death in the United States (www.alz.org). The first case of AD was published in 1907 by Dr. Aloysius "Alois" Alzheimer, who described a 51-year-old woman with serious memory loss. Post-mortem analysis of her brain showed severe brain atrophy and neuronal loss, as well as the presence of dense extracellular deposits and intracellular aggregates within neurons (Alzheimer, 1911; Graeber et al., 1997). These features were eventually identified as amyloid plaques and neurofibrillary tangles, respectively (Glenner and Wong, 1984; Grundke-Iqbal et al., 1986; Kosik et al., 1986), and the condition became known as Alzheimer's disease (Kraepelin, 1910).

Amyloid plaques are extracellular accumulations of $\beta$-amyloid $(A \beta)$ peptides that are derived from the proteolytic processing of the $\beta$ amyloid precursor protein (APP) (Goldgaber et al., 1987; Kang et al., 1987; Robakis et al., 1987; Tanzi et al., 1987). The $\gamma$-secretase complex cleaves APP at different positions, generating different size amyloidogenic peptides $A \beta_{43}, A \beta_{42}, A \beta_{40}, A \beta_{38}$, and $A \beta_{37}$ (De Strooper, 2010). Of these, $A \beta_{40}$ is the most abundant in both healthy and $A D$ brain tissue, whereas the $A \beta_{42}$ variant has been shown to be likely the most deleterious (Jarrett et al., 1993; Portelius et al., 2010). Much of our understanding of the mechanisms underlying AD pathology comes from a small population of individuals with early-onset familial $\mathrm{AD}$ ( $\mathrm{fAD}$ ). These cases harbor causal mutations involving primarily the $\mathrm{A} \beta$ processing enzymes, presenilin 1 and 2 (PSEN1, PSEN2), which are part of the $\gamma$-secretase complex (Levy-Lahad et al., 1995a; Levy-Lahad et al., 1995b; Rogaev et al., 1995; Schellenberg et al., 1993), or mutations within or duplications of the APP gene itself (Goate et al., 1991; Goate, 2006; St George-Hyslop et al., 1987).

The second defining characteristic of AD is the presence of neurofibrillary tangles (NFTs) comprised of intracellular accumulations of the microtubule-associated protein tau in affected neurons (Ballatore et al., 2007). The extent of tau pathology in human AD has been shown to correlate well to disease severity (Braak and Braak, 1991). Mutations in the gene encoding tau (MAPT) have been found to be causal for fronto-temporal dementia, although MAPT mutations have not been described in AD (Hutton et al., 1998; Spillantini et al., 1998). Overexpression of tau protein in mouse models has been shown to disrupt intracellular trafficking (Zhang et al., 2006), to induce axonal degeneration (Spittaels et al., 1999), and the humanized tau overexpression leads to neurofibrillary tangles formation in vivo (for review, see (Götz et al., 2007)). A number of promising drugs have reached late-stage (Phase III) clinical testing, however then failed to prevent cognitive decline (Doody et al., 2013; Doody et al., 2014; Salloway et al., 2014). The reasons are likely two-fold: first, the lack of human data for the successful stratification (separating patient population) according to disease phenotypes and/or genetic risk profiles (Blennow, 2010; Wolozin, 2012), and second, the species gap. Risk factors present in humans may not be adequately modeled in rodents. For example, while variants in the $A P O E$ gene are the strongest genetic risk factors for sporadic AD identified to date (Bertram et al., 2008; Corder et al., 1993; Farrer et al., 1997), the rodent genome has only one version of this gene.

A number of elegant mouse models have allowed the study of $\mathrm{AD}$ phenotypes in vivo in the brain, and have resulted in the basis of our current mechanistic understanding of the disease. However, a common drawback to these models is that they typically only capture specific aspects of $A D$ phenotypes such as $A \beta$ plaques or NFTs, but rarely the entire disease spectrum (Webster et al., 2014). Moreover, most mouse models focus only on the causative mutations in familial AD (fAD), such as those in the genes encoding presenilin 1 and 2 (PSEN1, PSEN2) and the amyloid-precursor protein (APP). These cases represent an extremely small percentage of the overall human AD burden; though models of fAD are invaluable, the majority of $A D$ cases are sporadic ( $S A D$ ). The genetic underpinnings of SAD may result from a combinatorial or additive effect of single nucleotide polymorphisms (SNPs) identified in genome-wide association studies (GWAS) (Lambert et al., 2013), while disease penetrance may depend on a host of non-genetic risk factors, such as age, head trauma, diabetes, lifetime stress, and environmental toxins, amongst others. Studying the distinct impact of ADassociated SNPs in mouse models is challenging, as these variants are often found in non-coding regions of the human genome. Using even the latest and most rapid genome editing techniques to insert multiple SNPs in homologous mouse genome regions would be onerous, expensive, and could be considered a high-risk undertaking. It is often not known whether a single SNP is disease causing, or whether it's a combination of several SNPs particularly as a number of different SNPs are commonly ascribed to a single locus.

\section{Human induced pluripotent stem (iPS) cells}

We will summarize the history, generation, and differentiation of human iPS cells only briefly, as many excellent reviews have covered these topics (Bouwman and de Laat, 2015; Parent and Anderson, 2015; Telias and Ben-Yosef, 2014). One fundamental question in the regeneration field is to find cells that maintain the capability to differentiate into the three germ layers: endoderm, mesoderm, and ectoderm. Embryonic stem (ES) cells have this "pluripotency" capability (Evans and Kaufman, 1981; Martin, 1981; Thomson et al., 1998). However, ethical issues tempered the initial excitement for human ES cells and therefore alternative strategies were needed (Hotta, 2008; Kamm, 2005). An important step was the discovery that the content of an oocyte's cytoplasm contained factors crucial for reprogramming somatic cells to an embryonic-like stage (Cowan et al., 2005; Tada et al., 2001; Wilmut et al., 1997). Takahashi et al. screened 24 of these factors and demonstrated that Oct3/4, Sox2, c-Myc, and Klf4 induced pluripotent stem cells from adult mouse fibroblasts (Takahashi and Yamanaka, 2006). A year later, the same group showed that they could reprogram human fibroblasts with these four "Yamanaka factors" into human pluripotent stem cells (Takahashi et al., 2007). Other groups have generated similarly pluripotent cells from other peripheral cells, such as blood cells (Okita et al., 2013) or urine-derived epithelial cells (Zhou et al., 2012). To distinguish these pluripotent stem cells from ES cells, the cells were named "induced pluripotent stem" (iPS) cells. Currently, much debate exists over the best method for reprogramming somatic cells into iPS cells, as well as how to assess the "stemness" of an iPS cell as compared to an ES cell line (Bock et al., 2011; Hanna et al., 2010; Lister et al., 2011). It is important to keep in mind that exogenous factors, genetic background, and epigenetic of tissue origin of cells influences naïve pluripotency (Hanna et al., 2010). Therefore certain differences on the epigenetic landscape are expected to exist between ES and iPS cells (Bock et al., 2011; Lister et al., 2011). Nevertheless, the advent of iPS cells allows one to generate any cell type of interest 


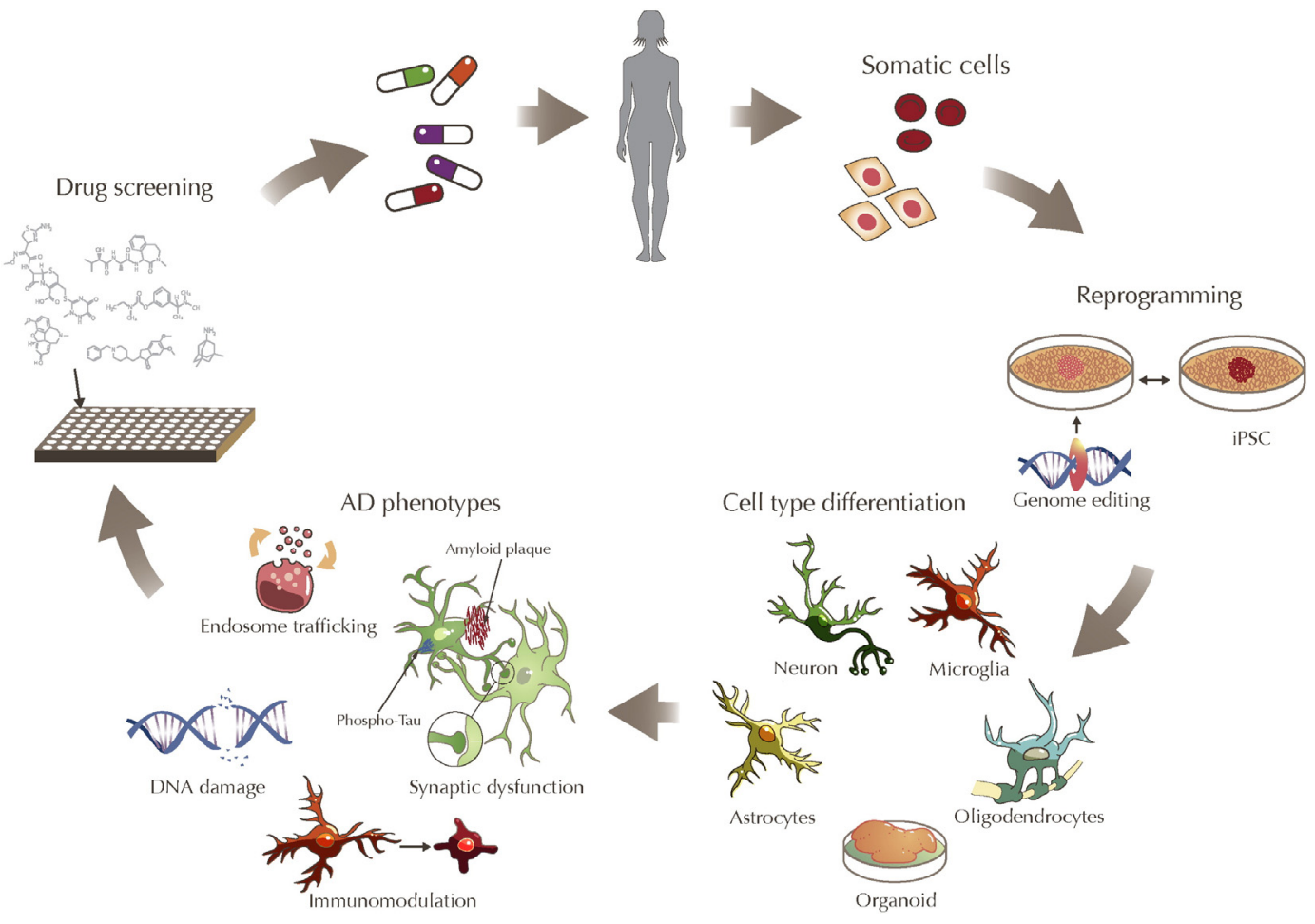

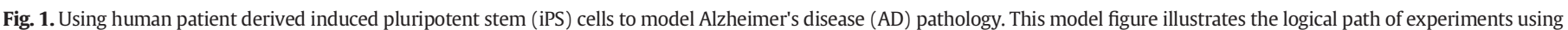

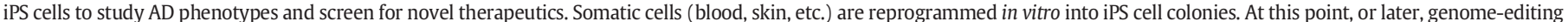

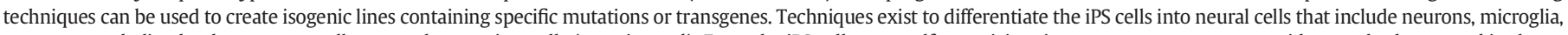

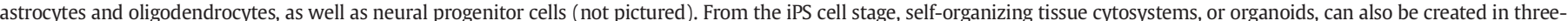

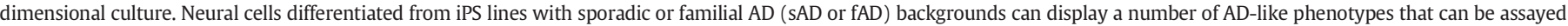

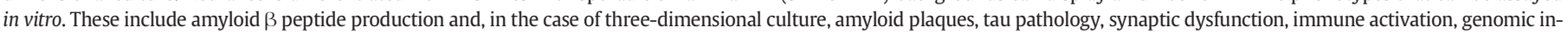

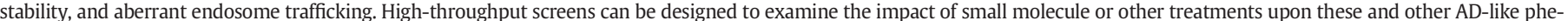
notypes directly in human neural cells. The development of novel treatments for the AD patient and the success of these treatments in the clinic completes the cycle.

from a patient's own somatic cells and to develop patient-specific drug treatments. Moreover, these techniques offer a nearly unlimited supply of human cells that can be deposited in repositories and shared between laboratories.

\section{Advantages to modeling neurological disease with iPS cells}

The study of human brain disease is hampered by the difficulties inherent to obtaining live material. The ability to generate neural cultures from post-mortem human brains depends greatly on the quality of the post-mortem brain tissue (Verwer et al., 2002). Prolonged agonal states such as hypoxia, coma, or ischemic brain damage could add confounding variables to these studies (Monoranu et al., 2009). This is not to mention the sheer difficulty of gaining access to reliable sources of human brain tissue. The generation of human iPS cells is one way to surmount these limitations. Protocols have been developed to differentiate iPS cells in vitro into distinct cell types allowing researchers to examine disease onset and progression directly in a human culture model (see Fig. 1). (Liu et al., 2012; Sandoe and Eggan, 2013). A number of studies have shown successful reprogramming of iPS cells from fibroblasts derived from individuals with various neurological diseases such as amyotrophic lateral sclerosis (Dimos et al., 2008), familial dysautonomia (Lee et al., 2009), Parkinson's disease (Park et al., 2008; Soldner et al., 2009), Rett syndrome (Marchetto et al., 2010), schizophrenia (Brennand et al., 2011), spinal muscular atrophy (Ebert et al., 2009; Yoshida et al., 2015), ADA-SCID, Gaucher disease type III, Duchenne muscular dystrophy, Becker muscular dystrophy, Down syndrome, Juvenile diabetes mellitus, Huntington disease (Consortium, 2012; N. Zhang, 2010; Q. Zhang, 2010), and Lesch-Nyhan syndrome (Mattis et al., 2015; Park et al., 2008) and AD (Choi et al., 2014; Hossini et al., 2015; Iovino et al., 2015; Israel et al., 2012; Koch et al., 2012; Kondo et al., 2013; Muratore et al., 2014; Wren et al., 2015; Yagi et al., 2011; Table 1).

\section{Drawbacks of iPS cells in neurological disease modeling}

The explosion in human iPS cell use has underscored the need to establish standardized protocols, as cell handling and other factors can influence phenotypes (Boulting et al., 2011). For example, variable Xinactivation in cells from female donors can have an impact upon both differentiation and phenotype (Boulting et al., 2011). Also, there is still debate regarding to what extent DNA methylation profiles, and other epigenetic attributes, might be maintained in iPS cells after reprogramming (Kim et al., 2010; Koche et al., 2011; Nazor et al., 2012; Ohi et al., 2011). To determine the magnitude and nature of variability amongst human iPS cells, Bock et al. (2011) performed a human genome-wide reference mapping of the DNA methylation across $20 \mathrm{ES}$ and 12 iPS cell lines. They established two scorecards for evaluating the quality and utility of human pluripotent cell lines; this kind of tool is crucial to the standardization of iPS protocols and is needed to obtain comparable and reproducible results.

Genetic diversity within and between populations, as well as disease onset and progression, can impact the experimental read-out from iPS cells (Rouhani et al., 2014; Soldner and Jaenisch, 2012). For example, common DNA variants may alter expression levels and pattern of many human genes (Majewski and Pastinen, 2011). Some groups have sought to overcome this diversity by focusing either on few phenotypes in a large collection of lines (Bock et al., 2011; Rouhani et al., 2014; Yoshimizu et al., 2015), or by investigating robust phenotypes in a smaller cohort (Chung et al., 2013; Israel et al., 2012). Each iPS cell study is challenged by the question of to what extent the observed phenotypes are related to the disease being modeled. For example, is the 
Table 1

Literature reviewed.

\begin{tabular}{|c|c|c|c|c|c|c|c|c|c|c|c|}
\hline Reference & Lab* & Year & PMID & Cell source & Disease & Mutation/gene & $\begin{array}{l}\text { Genome } \\
\text { editing/isogenic } \\
\text { lines }\end{array}$ & $\begin{array}{l}\text { Cell types } \\
\text { examined }\end{array}$ & Phenotypes reported & Drug treatment & Profiling \\
\hline $\begin{array}{l}\text { Yagi et al. } \\
\text { (2011) }\end{array}$ & Suzuki & 2011 & 21900357 & $\begin{array}{l}\text { iPSCs from Coriell } \\
\text { hFib: AG07768, } \\
\text { AG09908; Clone } \\
\text { 201B7 }{ }^{1}\end{array}$ & $\begin{array}{l}\text { fAD, } \\
\text { sporadic } \\
\text { PD }\end{array}$ & $\begin{array}{l}\text { PSEN1 A246E, } \\
\text { PSEN2 N141I }\end{array}$ & & Neurons & $A \beta$ & Compound E, Compound W & $\begin{array}{l}\text { Gene expression } \\
\text { microarray }\end{array}$ \\
\hline $\begin{array}{l}\text { Liu et al. } \\
\text { (2011) }\end{array}$ & $\begin{array}{l}\text { Izpisua } \\
\text { Belmonte }\end{array}$ & 2011 & 21346760 & $\begin{array}{l}\text { H9 ESCs; iPSCs from } \\
\text { BJ hFib, Coriell hFib: } \\
\text { AG01972, AG11498, } \\
\text { AG06297, } \\
\text { GM00038, } \\
\text { AG05247, AG09602. }\end{array}$ & $\begin{array}{l}\text { HGPS } \\
\text { progeria }\end{array}$ & LMNA G608G & & $\begin{array}{l}\text { Smooth muscle } \\
\text { cells }\end{array}$ & $\begin{array}{l}\text { Premature } \\
\text { senescence, nuclear } \\
\text { defects }\end{array}$ & & $\begin{array}{l}\text { DNA methylation } \\
\text { microarray }\end{array}$ \\
\hline $\begin{array}{l}\text { Israel et al. } \\
\text { (2012) }\end{array}$ & Goldstein & 2012 & 22278060 & $\begin{array}{l}\text { iPSCs from primary } \\
\text { patient hFibs }\end{array}$ & fAD, sAD & $\begin{array}{l}\text { APP } \\
\text { duplication }\end{array}$ & & NPCs, neurons & $\begin{array}{l}\text { Aß, Tau, GSK3 } \beta \\
\text { activity, endosomes, } \\
\text { vesicle trafficking, } \\
\text { synapse } \\
\text { formation/function }\end{array}$ & Compound E, DAPT & $\begin{array}{l}\text { Gene expression } \\
\text { microarray }\end{array}$ \\
\hline $\begin{array}{l}\text { Koch et al. } \\
\text { (2012) }\end{array}$ & Walter & 2012 & 22510327 & $\begin{array}{l}\text { ESCs: I3 (TE03); } \\
\text { iPSCs: } \text { PKa }^{2}\end{array}$ & fAD, & $\begin{array}{l}\text { Overexpres- } \\
\text { sion of PSEN1 } \\
\text { L166P and } \\
\text { D385N }\end{array}$ & & $\begin{array}{l}\text { It-NES cells, } \\
\text { NPCS, neurons }\end{array}$ & $A \beta$, NPC proliferation & $\begin{array}{l}\text { DAPT, ibuprofen } \\
\text { indomethacin }\end{array}$ & \\
\hline $\begin{array}{l}\text { Maclean } \\
\text { et al. } \\
(2012)\end{array}$ & Orkin & 2012 & 23045682 & $\begin{array}{l}\text { ESCS: CSES2 and } \\
\text { CSES13 } 3^{3} \text {. iPSCs: DS2, } \\
\text { DS1 MRC5-IPS7 }\end{array}$ & DS & Trisomy 21 & $\begin{array}{l}\text { Spontaneous disomic } \\
\text { isogenic lines }\end{array}$ & $\begin{array}{l}\text { Hematopoietic } \\
\text { cells }\end{array}$ & $A \beta$, hematopoiesis & & \\
\hline $\begin{array}{l}\text { Shi et al. } \\
\text { (2012b) }\end{array}$ & Livesey & 2012 & 22344463 & $\begin{array}{l}\text { ESCS: DS-ES SC-321, } \\
\text { H9; iPSCs: } \\
\text { DS1-iPS4 }\end{array}$ & DS & Trisomy 21 & & NPCs, neurons & $A \beta$, aggregates, Tau & DAPT & \\
\hline $\begin{array}{l}\text { Kondo et al. } \\
\text { (2013) }\end{array}$ & Inoue & 2013 & 23434393 & $\begin{array}{l}\text { iPSCs from primary } \\
\text { patient hFibs }\end{array}$ & fAD, SAD & $\begin{array}{l}\text { APP E693 } \triangle \text { and } \\
\text { V717L }\end{array}$ & & $\begin{array}{l}\text { Neurons, } \\
\text { astrocytes }\end{array}$ & $\begin{array}{l}\mathrm{A} \beta \text {, cellular/oxidative } \\
\text { stress, } \\
\text { Tau, neural }\end{array}$ & $\begin{array}{l}\text { DHA, DBM14-26, NSC23766, } \\
\text { BACE inhibitor IV (BSI) }\end{array}$ & $\begin{array}{l}\text { Gene expression } \\
\text { microarray }\end{array}$ \\
\hline $\begin{array}{l}\text { Fong et al. } \\
\text { (2013) }\end{array}$ & Huang & 2013 & 24319659 & $\begin{array}{l}\text { iPSCs from primary } \\
\text { patient hFibs }\end{array}$ & FTD & MAPT A152T & Zinc finger nucleases & NPCs, & $\begin{array}{l}\text { degeneration, } \\
\text { dopaminergic } \\
\text { phenotypes }\end{array}$ & & \\
\hline $\begin{array}{l}\text { Xu et al. } \\
\text { (2013) }\end{array}$ & Zhong & 2013 & 23305945 & $\begin{array}{l}\text { ESCs: H9, iPSCs: } \\
\text { hiPS-C4 line. iCell } \\
\text { Neurons. }\end{array}$ & $\mathrm{AD}$ & Exogenous $A \beta$ & & NPCs, neurons & $\begin{array}{l}\text { Neuronal viability, } \\
\text { cell cycle, } \\
\text { neurogenesis, } \\
\text { differentiation }\end{array}$ & Cdk inhibitors & Compound screen \\
\hline $\begin{array}{l}\text { Weick et al. } \\
\text { (2013) }\end{array}$ & Bhattacharyya & 2013 & 23716668 & $\begin{array}{l}\text { iPSCs from Coriell } \\
\text { hFib: AG05397, } \\
\text { GM02504. }\end{array}$ & DS & Trisomy 21 & $\begin{array}{l}\text { Disomic isogenic cells via } \\
\text { mosaicism }\end{array}$ & NPCs, neurons & $\begin{array}{l}\text { Cellular/oxidative } \\
\text { stress, Synapse } \\
\text { formation/function }\end{array}$ & & $\begin{array}{l}\text { Gene expression } \\
\text { microarray }\end{array}$ \\
\hline
\end{tabular}


201324315443 iPSCs from Coriell HGPS LMNA C1824T hFib: AG06917, Progeria, PINK1 Q456X; AG06297, AG11498 PD Parkin V324A.

Studer$$
\text { Parkin V324A. }
$$

dysfunction

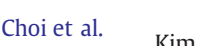

$\begin{array}{lll} & \text { ReN cell VM human } \\ 201425307057 & \text { neural stem (ReN) } \quad \text { fAD }\end{array}$ cells (Millipore)

\section{Overexpres-}

Hibaoui

et al. Feki

$201424375627 \begin{aligned} & \text { iPSCs from primary } \\ & \text { patient hFibs }\end{aligned}$ DS

Muratore

et al.
(2014)

$\begin{array}{llll}\text { Young-Pearse } 201424524897 & \text { iPSCs: hFibs from } \\ \text { HSCI }\end{array}$

$\mathrm{HSCl}$

fAD

Sproul et al., Noggle (2014)

Coriell AG07671,

AG07768, AG08446

fAD

Wren et al. Bu

201526373282 iPSCs from primary FTD

MAPT N279K

iPSCs from primary

Iovino et al. $\quad$ Spitlient hFibs, Coriell

(2015) Spillantin

201526220942

hFib: ND32854,

FTD

ND40076

Young et al. Goldstein
(2015)

Murray et al. Nizetic

(2015)

201525772071 hFibs from UCSD

ADRC, J.C.V.

SAD

Young adult hFibs

201525694335 from Galliera

Genetic Ban

Chang et al. Su

201525735452 iPSCs: allantoic

fluid-derived

$\begin{array}{ll}201525765079 & \begin{array}{l}\text { ESCs: H1, H9 } \\ \text { iPSCs: NFH-46 hFibs }\end{array} \text { SAD }\end{array}$
Sion of APP

M671L/V717I:

PSEN1( $\triangle \mathrm{E} 9)$

Trisomy 21

Isogenic cells from

discordant monozygotic

twins

APP V717I

PSEN1 A246E,

M146L

3D neural

culture in

Matrigel

$A \beta$, Tau, neural

degeneration

Compound E, BACE inhibitor IV

(BSI), DAPT, SGSM4

Synapse number, NPC $\begin{array}{lll}\text { NPCs, neurons, } & \begin{array}{l}\text { viability, DYRK1A } \\ \text { neurospheres }\end{array} & \text { activity, neurogenesis, }\end{array} \quad$ epigallocatechine gallate (EGCG) RNA-Seq differentiation

iPSCs, NPCs, $\quad$ AB, Tau, APP cleavage, DAPT, Compound E, BACE Nanostring gene

Neurons

endosomes

nhibitor

iPSCs, NPCs,

neurons

$A \beta$, differentiation

Recombinant Norrin

Gene expression

Tau, endosomes,

vesicle trafficking,

cellular/oxidative

stress

MAPT N279K,

P301L

dysfunction, $\alpha$

synuclein,

neurogenesis,

RNA-Seq

SORL1 SNPS

$A \beta$, SORL1 induction

NPCs, neurons

Disomic isogenic cells via

Neurons,

mosaicism

$A \beta$, mitochondrial

dysfunction, DNA

damage, proliferation

Trisomy 21

NPCs, neuron

$\mathrm{A} \beta$, aggregates, Tau,

Wnt signaling

F127-Bdph

NPCs/neurons

Compound E 
phenotype influenced by protective or exacerbating factors in the individual's genotype? Recent advances in genome editing techniques, particularly the use of Cas9 nuclease-based strategies, have made the generation of isogenic iPS cell practicable (F. Zhang et al., 2014; Y. Zhang et al., 2014; D. Zhang et al., 2014) and this technology can address the variability inherent in the human genome to some extent.

\section{Creating isogenic iPS cell lines as a strategy to overcome variability in human genomes}

The advent of homology-directed repair techniques for genome editing proved a major advance in our ability to manipulate the human genome. Currently, three systems have been established to perform DNA repair directed genome editing: zinc-finger-nucleases (ZFN), transcription activator-like effector nucleases (TALENs), and the clustered regularly interspaced short palindromic repeats (CRISPR) system that uses the Cas9 nuclease. All these nucleases induce guided DNA breaks. The repair of these breaks then either leads to insertion or deletion (indel) mutations, or the break can be repaired by homologous recombination with a donor vector carrying the desired mutation (Byrne et al., 2014). For a detailed review of the function of each of the nucleases, please refer to the reviews from Hsu et al. (2014), Sander and Joung (2014) as well as to descriptions of experimental strategies and protocols for human pluripotent cells in particular (Byrne et al., 2014; Chiba and Hockemeyer, 2015; Zhu et al., 2014).

The first generation of enzyme-directed genome editing used ZFNs. A number of important papers used the first generation ZFNs to generate isogenic iPS cells (Carroll, 2011; Urnov et al., 2010)) by knocking down genes such as PITX3 (Hockemeyer et al., 2009) or PIG-A (Zou et al., 2009), or correcting disease-related mutations in genes such as $\alpha 1$-anti-trypsin (Yusa et al., 2011), $\alpha$-synuclein (SCNA (Ryan et al., 2013; Soldner et al., 2011), and tau (MAPT (Fong et al., 2013). However, the success of this technique is limited due to the challenging design of a robust engineered zinc finger nuclease (Hsu et al., 2014; Ma et al., 2015; Sander and Joung, 2014). The development of the second generation TALEN technique overcame some of the limitations of the ZFNs by being less context-dependent and easier to design (Joung and Sander, 2013; Miller et al., 2011; Sander and Joung, 2014), while the efficiency is similar between the two paradigms (Hockemeyer et al., 2011). Human iPS models established with TALEN technology include manipulations in the APOB, SORT1, AKT2, PLIN1 (Ding et al., 2013a, 2013b), PSEN1 (Woodruff et al., 2013), and DISC1 (Wen et al., 2014). The third generation of genome editing tools is comprised of the CRISPR/Cas9 systems, which are based on the use of the RNAguided Cas9 nuclease (Jinek et al., 2012; Mali et al., 2013; Ran et al., 2013). One major advantage of the CRISPR system is that the Cas9 component is fixed, and the targeting sequence is supplied via a single-guide RNA (sgRNA); thus, targeting sequences can be easily exchanged or multiplexed by testing multiple sgRNAs (Ding et al., 2013a, 2013b). Several groups generated iPS cells that stably or inducible express the Cas9 protein. This system allows for rapid cellbased screens to test the consequences of multiple gene knockdowns using sgRNA libraries (Shalem et al., 2014; Wang et al., 2014; Zhu et al., 2014). Algorithms have been developed that predict off target effects of CRISPR-mediated genome editing, which, combined with falling costs for deep sequencing, allow researchers to minimize off-target effects (Hsu et al., 2013; Tsai et al., 2015; Slaymaker et al., 2015).

The advantage of isogenic lines is that only the disease-associated difference is studied, as the genetic background of the lines should be identical. While this is ideal for the study of disease causative mutations, other genetic variants, such as a haplotype of SNPs, are more difficult to model because they may only be relevant to disease risk in combination. Therefore, it seems advisable to both correct the mutation of interest in a patient-derived cell line, while in parallel introducing it in a control line. Techniques using mutated Cas9 linked to transcriptional activators or repressors also allow us to examine the consequences of enhanced or suppressed expression of specific genes without alterations to the genome itself (Qi et al., 2013). Therefore, genome editing will be an important strategy to minimize the effect of background variations in human iPS cell-derived lines.

\section{6. iPS cells as a model for understanding AD onset and disease progression}

In the following chapter, we will focus on studies that use iPS cells to model AD-like phenotypes (summarized in Table 1). The two hallmark characteristics of $\mathrm{AD}$ in the human brain are first, accumulation of $\beta$-amyloid $(A \beta)$ peptides into extracellular aggregates $(A \beta$ plaques), and second, the intracellular accumulation of phosphorylated species of the microtubule-associated protein tau into neurofibrillary tangles (NFTs). Both parameters can be measured in vitro: alterations in the presence of $A \beta$ peptides can be measured from culture medium or cell lysates, and the ratios between different species of $A \beta$ peptides, such as the amount of $A \beta_{40}$ versus $A \beta_{42}$, are often reported. To examine tauopathy in AD cellular models, the abundance of different species of phosphorylated tau (pTau) is normalized against total tau levels. Other AD-like phenotypes that can be measured in cultured cells will also be discussed, including endosome cycling and DNA damage.

\subsection{Phenotypic characterization of iPS cell AD models}

Several groups have succeeded in creating functional neurons from fAD and SAD iPS cells: In 2011, Yagi et al. used fibroblasts of fAD patients with mutations in either presenilin isoform PSEN1 (A246E) or PSEN2 (N141I; Yagi et al., 2011). Using retrovirus carrying a five-factor reprogramming mix of OCT4, SOX2, KLF4, LIN28 and NANOG, they created iPS cells that were then differentiated mainly into neuronal cells. After two-week culturing, they observed an elevated ratio of $A \beta_{42}$ to $A \beta_{40}$ for the fAD lines compared to controls. The authors did not find any level of tauopathy, and speculated that the two-week maturation time may have been too short. Treatment of the cultures with the $\gamma$ secretase inhibitors Compound $\mathrm{E}$ and Compound $\mathrm{W}$ reduced both $A \beta_{40}$ and $A \beta_{42}$ levels, while only the highest dose of Compound $W$ appeared to impact the $A \beta_{42 / 40}$ ratio. This study was the first to establish a model of fAD phenotypes in iPS cell-derived neural cultures. However the drawbacks of this work might be the relatively short time of neuron maturation as well as the potential high variability between clones of the same genotype.

In 2012, Israel et al. provided a thorough evaluation of AD-like phenotypes in multiple iPS cell-derived neurons from both fAD and sAD individuals (Israel et al., 2012). They used retrovirus carrying the four Yamanaka factors OCT4, SOX2, KLF4, and c-MYC to create iPS cells lines from healthy, non-demented individuals, two sporadic AD patients, and two familial patients, who carried APP duplications. Neural progenitor cells were purified using fluorescence activated cell sorting and differentiated into heterogeneous neuronal cultures. They observed increased secreted $A \beta_{40}$ in neurons created from one $S A D$ and the two fAD lines. Importantly, the $A \beta$ levels did not differ in fibroblasts from the same individuals, supporting the idea that only distinct iPSderived cells can model disease-specific phenotypes. No changes were observed in the $A \beta_{42 / 40}$ or $A \beta_{38 / 40}$ ratios between cell lines, although the authors noted that detection of the less abundant $A \beta_{42}$ and $A \beta_{38}$ species were often below the detection range of the assay due to the small number of neurons. In a similar pattern, one SAD and both $\mathrm{ADD}$ lines showed increased phospho-tau and activation of the tau kinase GSK3 $\beta$. Treatment of the neuronal cultures with $\gamma$ - and $\beta$-secretase inhibitors reduced $A \beta_{40}$ in one sAD and one fAD line, while only $\beta$ secretase inhibitors lowered the levels of active GSK-3 $\beta$, and phosphotau. Another AD phenotype that can be characterized in iPS cellderived cultures is the presence of abnormal endosomes. Large, RAB5- 
positive early endosomes have been observed in AD mouse models and in the brains of SAD and fAD patients (Cataldo et al., 2001; Cataldo et al., 2000). These endosomes may contain aberrantly phosphorylated $A \beta$ (Lee et al., 2003). Impaired endocytic and mitochondrial trafficking has also been observed in iPS cell models of frontotemporal dementia (FTD) using cells from patients carrying mutations in the MAPT gene (Iovino et al., 2015; Wren et al., 2015). Israel et al. examined early endosome morphology in iPS-derived neurons seeded onto a layer of commercially-available human astrocytes, and found that the number of medium to large RAB5 + endosomes was increased in neurons derived from one SAD and one fAD compared to the two controls. Finally, they measured synapse formation and function. No differences were apparent in synapse number (synapsin immunoreactivity) or function (voltage clamp recordings) between the $\mathrm{AD}$ and control lines.

In 2013, Kondo et al. used episomal vectors to generate iPS cells from dermal fibroblasts from both sAD patients and fAD patients carrying the APP-V717L or the APP-E693 $\triangle$ fAD mutations (Kondo et al., 2013). The E693 $\triangle$ mutation leads to early-onset $A D$, but without amyloid deposition. Differentiated E693 $\Delta$ neurons showed decreased $A \beta_{40}$ and $A \beta_{42}$ compared to controls, while neurons from the V717L line have increased extracellular $A \beta$ and an increased $A \beta_{42 / 40}$ ratio. No significant $A \beta$ secretion was detectable in the medium of the sAD lines. The authors then established astrocyte-rich cultures using protocols modified from Su-Chun Zhang's work (Krencik and Zhang, 2011). Astrocytes from the $E 693 \triangle$ line and one of the SAD lines accumulated $A B$ oligomers Intracellularly They performed gene expression profiling of the astrocyte/neuronal co-cultures from E693 $\Delta$ and control cells and observed that oxidative stress-related categories were upregulated in the AD lines, suggesting ER and Golgi perturbation. The levels of these genes were reduced following treatment with DHA, known to alleviate oxidative stress, as well as the production of ROS, in E693 $\Delta$ cells, without altering the levels of $A B$.

Fong et al. (2013) used zinc-finger nucleases (ZFNs) to correct a A152T mutation in the MAPT gene (tau), as well as to create an isogenic line homozygous for the mutation, in iPS cells (Fong et al., 2013). Following neuronal differentiation, the heterozygous mutant tau neurons showed short, misshapen neurites with punctate tau and significant phospho-tau immunoreactivity. These phenotypes were absent in the corrected lines, and were significantly exacerbated in the homozygous mutant lines, which showed high degrees of phospho-tau (AT8) and blebbing of the neurites. While they found a low percentage of dopaminergic cells (DA) in the mutant lines, the corrected isogenic lines had 4 to 8 -fold increased number of DA neurons.

In addition to lines derived from $\mathrm{AD}$ patients, several groups have overexpressed fAD mutant versions of PSEN1 or APP in healthy iPS or ES cell lines (Choi et al., 2014; Koch et al., 2012). For example, neurons created from a human ES cell line were transduced, as neuroepithelial-like stem cells, with lentivirus carrying cDNAs for PSEN1 $1_{\text {wt }}$, PSEN1 $1_{\mathrm{D} 385 \mathrm{~N}}$, or PSEN1 $1_{\mathrm{L} 166 \mathrm{P}}$ under control of the EF1alpha promoter (Koch et al., 2012). By four weeks of neuronal differentiation, most of the $\beta$-III tubulin-positive cells were highly immunoreactive for APP. Interestingly, the inclusion of Exon 15 of APP, a splice variant associated with neurons, was present in neurons after 4 weeks compared to undifferentiated cells. Extracellular $A \beta$ level was reduced in these neuronal cultures following treatment with the $\gamma$-secretase inhibitor DAPT. In addition, NSAIDS, such as ibuprofen, slightly lowered $A \beta$ levels only in the PS1wt, but not the PS1D385N, overexpressing neurons. One early screening effort used commercially available iPS cell-derived neurons (iCell Neurons) to screen a library of several hundred compounds for their ability to ameliorate toxicity from exogenously applied $A \beta$ (Xu et al., 2013).

To date, most studies that model AD in patient-derived iPS cells utilize cell lines with defined fAD mutations in PSEN1 and APP While some studies include cells from SAD patients, the lack of a defined mutation means that isogenic lines cannot be made, and often information is lacking as to the severity or course of disease progression. Two studies in which SAD lines were included observed disease phenotypes similar to fAD cells in only one of two SAD samples (Israel et al., 2012; Kondo et al., 2013). Few studies include SAD lines, and this is a concern, as sporadic late-onset $\mathrm{AD}$ represents the vast majority of $\mathrm{AD}$ cases. While $60-80 \%$ of sAD may in fact have genetic underpinnings (Gatz et al., 2006), one's APOE genotype remains the only known robust factor affecting SAD risk. These issues add to the call for the development of $\mathrm{AD}$ biomarkers that can predict disease risk and age of onset. Much work has begun in this direction, and large-scale human genome-wide association studies (GWAS) combined with mouse and human epigenetic and transcriptome profiling, have derived lists of genes in which variants are consistently associated with an increased risk of $A D$ (Bertram et al., 2007). These genes tend to be implicated in vesicle trafficking/endocytosis, immune function, and cholesterol metabolism (for review see Olgiati et al., 2011)). One recent study (Young et al., 2015) focused upon iPS cells derived from individuals with sADassociated variants in the SORL1 gene, which encodes a protein involved in endocytic trafficking, and whose loss of expression has been observed in SAD brains. The authors found that the induction of SORL1 expression by brain-derived neurotrophic factor (BDNF) treatment, as well as the effect of SORL1 expression upon A 3 secretion, was affected by SORL1 genotype in differentiated human neurons. While these studies were hampered by significant variability, which was combated by the inclusion of a relatively large number of cell lines, it was the first to describe a phenotype in human iPS cell-derived neurons resulting from SAD-associated genetic variants. With the increased feasibility of genome editing in iPS cells, particularly to create point mutations, we anticipate that the near future will see many more reports elucidating the roles of SAD risk variants in iPS cell-derived neural cell models.

\subsection{AD phenotypes in Down syndrome iPS cells}

Down syndrome (DS) patients show a high incidence of early-onset AD-like dementia (40-60\%). The underlying reasons for this are not clear, but are presumably related to the triplication of the APP gene, as well as the tau kinase DYRK1A gene (Woods et al., 2001) on chromosome 21 (Beyreuther et al., 1993; Burger and Vogel, 1973; Lemere et al., 1996; Rumble et al., 1989). Therefore, neural cell models from DS individuals may improve both our understanding of AD-like pathology, as well as providing hope for therapies for DS (Editorial, 2013). To date, no genome editing protocols have been reported that allow for the correction or induction of trisomy in iPS cell models. However, the rare occurrence of monozygotic twins discordant for trisomy 21 (Hibaoui et al., 2014), as well as creation of iPS cell lines from individuals with mosaic DS (Murray et al., 2015; Weick et al., 2013), and the spontaneous reversion to disomy 21 in a DS iPS cell line (Maclean et al., 2012), provide us with isogenic lines with which to study this disorder. An early paper (2008) demonstrated AD-like deficits in endocytic function in fibroblasts from DS individuals (Cataldo et al., 2008). In 2012, the Livesey group created iPS cells from one DS patient and one control and examined them for AD-like pathology (Shi et al., 2012a, 2012b, 2012c). Interestingly, the DS line secreted far higher levels of both $A \beta_{40}$ and $A \beta_{42}$ as fibroblasts, than did control cells. Following two months in neuronal culture, aggregates of $A \beta_{42}$ were detected in the DS cultures using live staining with the thioflavin $\mathrm{T}$ analog BTA1 and immunocytochemistry against $A \beta_{42}$. A twenty-one day treatment with DAPT nearly abolished both species of $A \beta$ production in the DS neurons. Tau pathology was also evident in neurons differentiated from DS iPS cells, detectable as an abnormal distribution of phospho-tau within the neurons as well as secreted tau in the medium of DS cultures only. Synapse formation did not appear to differ between neurons from DS and control individuals. 
Chang et al. (2015) created neurons from both hES cell and iPS cell lines. Similar to Shi et al., the authors found increased immunoreactivity for $A \beta$ and phosphorylated tau in cells from DS individuals. Treatment with n-butylidenephthalide (Bdph), an activator of Wnt signaling, delivered via coated nanoparticles, ameliorated AD-like phenotypes in these cultures. Recently, accelerated aging phenotypes were reported in neurons derived from DS iPS cells compared to isogenic controls (Murray et al., 2015). Unlike previous models, these cells exhibited differences in proliferation and differentiation. Consistent with earlier reports, the DS iPS cell-derived neurons had increased AB immunoreactivity in fixed cultures, but did not appear to differ electrophysiologically from controls. The DS neurons also exhibit mitochondrial dysfunction and increased DNA damage compared to the controls. This last phenotype is particularly interesting, and the failure of neurons to maintain their genomic integrity appears to be a hallmark both of normal aging and of neurodegenerative disease (Dobbin et al., 2013; Goto, 1997; Hasty et al., 2003; Kim et al., 2008; Lovell and Markesbery, 2007; Lu et al., 2004; Sahin and DePinho, 2010; S. Wang et al., 2013; W.Y. Wang et al., 2013). In conclusion, iPS cell-derived neurons from DS individuals may be useful for modeling phenotypes that are similar between $\mathrm{AD}$ and aging in $\mathrm{DS}$, as these cells appear to exhibit both amyloid and tau pathology as well as phenotypes such as endosome dysfunction and DNA damage.

\section{Disadvantages in modeling AD with iPS cells}

\subsection{Aging in iPS cells}

Work by several groups has suggested that reprogramming of the iPS cells "re-sets" the epigenome, and that other phenotypes associated with cellular aging, such as mitochondrial function and telomere length, are returned to a "juvenile-like" state (Mahmoudi and Brunet, 2012; Miller and Studer, 2014). This raises the question: can we model phenotypes associated with aging in human neural cells (Isobe et al., 2014)? Transplantation studies of human neuronal progenitor cells (NPCs) into the rodent brain have suggested that the human neural cells mature on a human, rather than a rodent, timeline (Espuny-Camacho et al., 2013). However, simply allowing iPS cells-derived neural cells to age in vitro is impracticable and expensive. Therefore, several groups have begun to explore the possibility of accelerated aging in these model systems. One approach is to derive iPS cells from individuals with Hutchinson-Gilford Progeria syndrome (HGPS), who express a truncated product of the mutated LMNA gene, progerin, which triggers fast aging (Blondel et al., 2014; Liu et al., 2011). Liu et al. found that the deleterious progerin protein was absent in HGPS patient-derived cells in the iPS cell stage (Liu et al., 2011). However, upon differentiation to smooth muscle cells, the disease phenotype of progerin accumulation, as well as its aging-associated cellular defects, were recapitulated. In place of using patient cells, progerin can also simply be overexpressed in iPS cells to induce age-related phenotypes such as DNA damage and mitochondrial dysfunction (Miller et al., 2013). Increases in DNA damage have also been observed in iPS cells derived from individuals with Werner Syndrome, an accelerated aging disorder arising from mutations in the WRN gene, which encodes a DNA helicase (Shimamoto et al., 2015).

Instead of progerin overexpression, other "stimulating" factors might be used to activate aging pathways. An interesting example has been shown in cardiomyocytes from differentiated iPS cells of patients with arrhythmogenic right ventricular dysplasia. These cells were exposed to a three-factor cocktail, which activates PPAR $\alpha$ and leads to increased fatty acid oxidation instead of glycolysis (Wen et al., 2015). In this way, the authors recapitulate the adult cardiomyocyte-like metabolism in these cells, which could be pushed to the desired disease pathologies by further treatment with PPAR $\gamma$ activators. Although these techniques appear to induce aging phenotypes in iPS cell derivatives, we first have to understand the underlying association of aging with $\mathrm{AD}$ to incorporate systematic approaches to age neurons.

\subsection{Neuronal maturation}

In all iPS cell approaches, it is necessary to confirm the maturity and the functionality of the derived neurons. While some studies in neurodegenerative disorders use nestin and Pax6-positive NPCs as a kind of proxy to neurons (Hossini et al., 2015), others have gone to lengths to demonstrate the degree to which iPS cell-derived neurons model in vivo human neurons (Israel et al., 2012). The most common methods to confirm neuronal differentiation and matureness are a combination of immunocytochemistry and electrophysiology (Israel et al., 2012; Nieweg et al., 2015): mature neurons should show the ability to fire action potentials when depolarized under current clamp, as well as demonstrating spontaneous excitatory and inhibitory postsynaptic currents under single-cell patch-clamp. Immunocytochemistry for synaptic vesicle proteins, such as VGLUT1, VAMP2, synaptobrevin, and synapsin, are indicative for mature functional synapses (Marchetto et al., 2010; Nieweg et al., 2015). One early screening effort emphasized the need to create mature neuronal cultures for reliable drug assays (Yahata et al., 2011). Thus, one major challenge to researchers is to provide neuronal cultures that are both mature enough to be representative of adult brain neurons, while being abundant enough for multiple types of assays. Occasionally the presence of disease mutations may hamper efforts to create human neural cell models of disease. For example, neurons created from patient-derived iPS cells carrying FTD mutations in MAPT have been shown to mature more quickly than control lines, while at the same time displaying disease phenotypes such as hyperphosphorylated Tau (Iovino et al., 2015). In contrast, another group using iPS cell-derived neurons carrying the same MAPT mutation $(\mathrm{N} 279 \mathrm{~K})$ reported that these cells had deficits in neuronal maturation compared to control lines (Wren et al., 2015). The issue of altered proliferation and/or differentiation of neural progenitor cells and neurons seems particularly troublesome in work with Down syndrome lines (Hibaoui et al., 2014; Murray et al., 2015).

\subsection{Culture heterogeneity and disease phenotypes}

Another important aspect is that in several studies it is not obvious to what extent the reported neuronal cultures contain other cell types, nor whether heterogeneous cultures may encourage neuronal differentiation (Sandoe and Eggan, 2013; Shi et al., 2012a, 2012b, 2012c). While pure cultures of neurons can form synapses and display connectivity, they may not mature fully in the absence of astrocytes or glialconditioned medium (Pfrieger, 2009; Pfrieger and Barres, 1997; Ullian et al., 2004). Along these lines, some groups have found that the addition of astrocytes to iPS cell-derived neuronal cultures enhances the ability to obtain mature neurons (Odawara et al., 2014; B. Zhang et al., 2013; Y. Zhang et al., 2013); this is an area of active debate and constant methodological improvement. Overall, it is necessary to fully characterize the cell type matureness as well as the heterogeneity of neural cultures derived from iPS cells. In this regard, the advent of three-dimensional neural cultures derived from human iPS cells may be particularly beneficial, as discussed later.

Finally, a major challenge is to generate a distinct cell type to study its involvement in a disease phenotype. It is hypothesized that only a certain subset of cells fails in many neurological diseases, for example, a subpopulation of dopaminergic cells in Parkinson's disease (Sandoe and Eggan, 2013). Moreover, the phenotypes displayed by cells bearing physiological mutations, such as familial AD mutations, may often be less robust than those obtained via the experimental overexpression of mutant proteins. One study compared the effect of compound treatment on neural cells from fAD patients to either heterologous cell lines overexpressing fAD APP, or human control ES-derived neural cells overexpressing mutant APP. They observed that concentrations of 
indomethacin that reduced $A \beta_{42 / 40}$ robustly in the heterologous cells, and more modestly in the APP-overexpressing human cells, had no effect on the human neural cells carrying endogenous fAD mutations (Mertens et al., 2013). Most researchers who use patient-derived iPS cells carrying familial mutations will be familiar with this issue of comparatively mild disease phenotypes, at least compared to models of gene overexpression or knockdown. Fortunately, the use of isogenic lines with corrected disease alleles may, by reducing variability between lines, allow for the reliable measurement of even modest phenotypes. The increased use of three-dimensional tissue culture systems (see Section 8), may also facilitate disease phenotypes by concentrating protein aggregates and other cellular products in a tissue-like environment that can still be imaged or assayed with ease.

In addition to the issue of variability between iPS cell-derived lines in assays of disease phenotypes, we are faced with the growing awareness that other cell types must be created to model AD in these systems. For example, in the last decade, it has become obvious that glia cells have an important impact in disease onset and progression. Thus, our basic science interests demand that we increase the complexity of our cellular models to adequately represent the disease, while at the same time we are tasked with the production of simplified systems that are amenable to applications such as drug screening.

\section{Differentiation of iPS cells to study cell type-specific impact to- ward neurological diseases}

Generation of iPS cells typically serves as a starting point to differentiate them into various brain-specific cell types such as neurons or glial cells. Each cell lineage develops when a combination of exogenous morphogens are applied at distinct time points during development of the iPS cells (Liu and Zhang, 2011). An alternative strategy is the overexpression of cell type-specific transcription factors (B. Zhang et al., 2013; Y. Zhang et al., 2013). In the following, we focus on examples of the successful generation of neuronal and glial cell types from human iPS cells.

\subsection{Differentiation to distinct neuronal cell types}

The initial iPS cell study by Takahashi et al. demonstrated the successful generation of neuronal cells from iPS cells (Takahashi et al., 2007). It is now common to perform neuronal differentiation (Denham and Dottori, 2011), and even to differentiate into specific neuronal subtypes, such as forebrain glutamatergic neurons (Zeng et al., 2010), cortical neurons (Nieweg et al., 2015; Shi et al., 2012a, 2012b, 2012c), GABAergic interneurons (C.C. Liu et al., 2013; Y. Liu et al., 2013; Nieweg et al., 2015), motor neurons (Ebert et al., 2009), and hypothalamic-like neurons (Wang et al., 2015). Indeed, there are too many neuronal differentiation techniques in the literature to adequately review here (some recent reviews include (Broccoli et al., 2015; Broccoli et al., 2014; Chinchalongporn et al., 2015; Lai et al., 2015)). The generation of inhibitory neurons is of particular interest for AD research, since both inhibitory and excitatory neurons are affected (Hazra et al., 2013; Krantic et al., 2012), and inhibitory interneurons, such as parvalbuminergic cells, play crucial roles in orchestrating large networks crucial to memory formation (Bartos et al., 2007; Mann and Paulsen, 2007). The development of protocols for the differentiation of multiple neural subtypes is a lively area of research.

\subsection{Differentiation to glia}

In the brain, glial cells can be divided in three major cell classes: astrocytes, microglia, and oligodendrocytes. Each of them has been proposed to have an important impact in AD onset and progression; even so, it remains debatable whether alterations in glia are causative for disease or represent secondary effects. Overall, human AD and mouse gene expression studies show that, with $\mathrm{AD}$ progression, immune response and inflammatory genes are up- and genes involved in neuronal functions are down-regulated (Blalock et al., 2011; Blalock et al., 2004; Gjoneska et al., 2015). Interestingly, GWAS describe several AD-risk increasing genetic variants linked to genes with identified roles in glial cells, such as APOE, PICALM, TREM2, CR1, CD33 and CLU (Ando et al., 2013; Antunez et al., 2011; Bertram et al., 2008; Bradshaw et al., 2013; Calero et al., 2000; Corneveaux et al., 2010; Crehan et al., 2013; Deng et al., 2012; Guerreiro et al., 2013; Harold et al., 2009; Hollingworth et al., 2011; Jonsson et al., 2013; Lambert et al., 2009; Lambert et al., 2010; Wunderlich et al., 2013; N. Zhang, 2010; Q. Zhang, 2010). Apolipoprotein (APOE) was originally identified in the liver, where it mediates the transport and delivery of cholesterol and other lipids through cell surface ApoE receptors (Mahley, 1988; Mahley and Rall, 2000). The human APOE gene exists as three alleles. While these three variants have a frequency in the population of $8.4 \%$ ( $\varepsilon 2), 77.9 \%(\varepsilon 3)$, and $13.7 \%$ ( $\varepsilon 4)$, the frequency of the APOE $\varepsilon 4$ variant (APOE4) is increased to at least $40 \%$ in sporadic AD patients (Farrer et al., 1997) making it the greatest known risk factor for SAD (Kanekiyo et al., 2014; Lambert et al., 2013). Individuals with one APOE4 allele are three to four times more likely to develop AD than those without APOE4 alleles, an odds ratio that is by far the highest out of any AD risk gene (Bertram and Tanzi, 2008; Corder et al., 1993). In both humans and in animal models, the APOE4 allele is associated with increased levels of amyloid beta $(A \beta)$, as well as amyloid plaque deposition (Castellano et al., 2011; Fryer et al., 2005; Kim et al., 2009; Youmans et al., 2012). The least common variant, APOE2, differs from the APOE4 variant at just two amino acid positions but appears to be protective against the development of $\mathrm{AD}$ ( $\mathrm{Bu}, 2009$; Corder et al., 1993; Y. Liu, 2013; C.C. Liu, 2013). While the contribution of the APOE4 allele to AD risk is well known, the reasons as to why this variant may trigger $\mathrm{AD}$ are not at all understood. The study of these APOE variants has been particularly difficult in rodent models, which endogenously express only one version of the Apoe gene. Thus, the emergence of iPS cell lines with different $A P O E$ isotypes will greatly advance our understanding of this AD risk factor by either collecting individuals of particular genotypes, or by using genome editing to "switch" between the protective and the disease-causing $A P O E$ form within the same genotype.

Taken together, two important themes emerge from these observations: 1) neurodegeneration in $\mathrm{AD}$ most likely involves an interaction of neuronal and glial pathologies; and 2) understanding the functions of genes implicated in $\mathrm{AD}$, from GWAS or expression studies, will require a thorough characterization of their functions in a cell type-specific manner. Since human and mouse glia are surprisingly divergent (Oberheim et al., 2006; Oberheim et al., 2009), which places emphasis on the need for models of human glia for the study of neurodegenerative disease.

\subsubsection{Astrocytes}

Astrocytes are a diverse cell class, which can differ both functionally and morphologically between brain regions (Bribian et al., 2015; Ma et al., 1999; Tabata, 2015) as well as displaying significant species divergence (Oberheim et al., 2006; Oberheim et al., 2009). Astrocytes are intimately involved in synaptogenesis and synapse maintenance (Haydon and Nedergaard, 2015; Pascual et al., 2005; Perea et al., 2009), maintain brain homeostasis, store and distribute energy substrates, and play a major role in the clearance of metabolites and toxins from the brain parenchyma (Jessen et al., 2015; Xie et al., 2013). Inflammatory astrogliosis precedes or accompanies neurodegeneration in many animal models and human postmortem AD brains, as evidenced by increased immunoreactivity for glial fibrillary acidic protein (GFAP) as well as by the loss of important astrocytic proteins such as glutamine synthase and GLT-1 (Dabir et al., 2006; Fischer et al., 2005; Li et al., 1997; Masliah et al., 2000; Robinson, 2001; Tilleux and Hermans, 
2007). Moreover, astrocytes in the brain are the primary producer of the ApoE protein under physiological conditions, although cell profiling studies have implicated microglia as another prominent ApoE source (F. Zhang et al., 2014; Y. Zhang et al., 2014; D. Zhang et al., 2014).

While differentiation from iPS cells focused initially on creating functional human neurons, several groups have now also developed protocols to differentiate astrocytes from iPS cells. In spontaneously differentiating cultures, astrocytes will appear roughly 100 days from the time that neural progenitor cells are placed in differentiation media (Shi et al., 2012a, 2012b, 2012c). To more quickly obtain cultures with a higher purity of astrocytes, techniques have been developed to obtain astrocytes from gliospheres (Krencik et al., 2011) or by directed differentiation via defined factors (Chen et al., 2014). Astrocyte-like cells can also be obtained via direct reprogramming of fibroblast cells (Caiazzo et al., 2015). The admirable plasticity of these glial cells, however, which make them such an important and adaptable cell in the brain, has historically led to issues of how representative primary cultured astrocytes are compared to the in vivo situation (Foo et al., 2011; Hertz et al., 1998; Sun et al., 2013). Given the different protocols in development to create iPS cell-derived human astroglia, the issue of variability between different groups and different cell lines is likely to require a concerted effort by the entire neural iPS cell community to address this issue.

\subsubsection{Microglia}

Microglia are complex and dynamic cells that respond to their environment by releasing chemical transmitters as well as phagocytosing cell debris, synapses, or whole cells. Both pro-inflammatory and neuroprotective roles for microglia have been demonstrated in AD. Local resident microglia become activated and rapidly react to amyloid plaque formation by extending processes, migrating toward plaques, and aggregate around them (Bolmont et al., 2008; Lue et al., 2001). Also, microglia are demonstrated to undergo apoptosis in AD brain (Lassmann et al., 1995; Sugaya et al., 1997; Yang et al., 1998) and show dystrophic morphology and fragmentation, which could underlie senescence in these cells (Streit et al., 2009; Streit and Xue, 2010).

The differentiation of microglia from iPS cells appears possible, though perhaps more challenging than other neural cell types, given the unique origin of microglia (Ginhoux et al., 2010). To date, however, while publications exist for creating mouse microglia (Beutner et al., 2010; Beutner et al., 2013; Selvaraj et al., 2012; Tsuchiya et al., 2005), resources describing human iPS cell-derived microglia are rare. We found one patent related to the "Method for obtaining human microglial precursor cells from pluripotent stem cells" (EP 2424976 A1) from the group of Harald Neumann (Neumann et al., 2013), who also have derived microglial cells from mouse ES cells (Beutner et al., 2010; Beutner et al., 2013). Another strategy was introduced by the Filgueira group, who generated microglia from human peripheral blood monocytes using a mixture of recombinant cytokines such as M-CSF, GM-SF, NGFB, and CCL2 (Etemad et al., 2012). A report that focuses on the analysis of FTD phenotypes in iPS cell-derive neurons mentions the creation of Iba1-positive cells from embryoid bodies, but does not further characterize these cells (Almeida et al., 2012). Some groups have found that, in the process of making embryoid bodies and three-dimensional cultures, that they are able to isolate $\mathrm{Cd} 11 \mathrm{~b}+/ \mathrm{CD} 45+$ monocyte-like cells (Schwartz et al., 2015). However, whether these microglial precursors demonstrate the same characteristics as microglia in vivo is a matter of debate, and our understanding of microglia and their roles in Alzheimer's disease remains woefully incomplete. To date, we could not find any work in the literature that focused upon creating microglia from human ES or iPS cells. The production of microglia from human iPS cells is highly desirable, given our increasing awareness of the role of inflammation in neurodegenerative disease, and we look forward to seeing new protocols in the literature soon.

\subsubsection{Oligodendrocytes}

Oligodendrocytes form myelin layers around neuronal axons in order to allow high nerve conductance (Bercury and Macklin, 2015). White matter lesions and myelin abnormalities have been described in human AD brain and mouse models (Bartzokis, 2011; Desai et al., 2010; Desai et al., 2009; Englund et al., 1988; Kobayashi et al., 2002; Roth et al., 2005). The potential that iPS cell-derived oligodendrocyte precursor cells and mature oligodendrocytes have for both the study and treatment of demyelinating disorders has made this an active field, with a number of groups developing protocols. These studies have generated oligodendrocytes and oligodendrocytes precursors from human iPS cells either as a component of heterogeneous cultures (Hu et al., 2009; Kim et al., 2012; Swistowski et al., 2010) or as the result of concerted efforts to generate these particular cell types (Douvaras et al., 2014; Jang et al., 2011; Ogawa et al., 2011; Pouya et al., 2011; S. Wang et al., 2013; X.Y. Wang et al., 2013). Oligodendrocytes derived from human iPS cells have been shown to myelinate neuronal processes in vitro (S. Wang et al., 2013; X.Y. Wang et al., 2013) and in vivo (Douvaras et al., 2014; Major et al., 2011; Pouya et al., 2011; S. Wang et al., 2013; X.Y. Wang et al., 2013), and thus hold great promise for studying the impact of myelin abnormalities in AD and other demyelinating disorders.

\subsection{Future challenges for cell type differentiation}

For each cell type differentiation, it will be crucial to eliminate remaining pluripotent iPS as well as progenitor cells. There are several options such as fluorescent-activated cell sorting (Sergent-Tanguy et al., 2003) or magnetic separation, however, the processes involved potentially risk changing the epigenetic landscape. It would be an advantage to have a marker of successful differentiation. For example, Kim et al. (2011) showed that the microRNA-371-3 cluster could serve as a discrimination factor for neuronal differentiation.

One major challenge will be to define what is a cell type and which cell type is impacted in a disease phenotype. To define a cell type is challenging by itself (DeFelipe et al., 2013; Fishell and Heintz, 2013; Grange et al., 2014) but solving this question will be crucial for future studies in iPS cells. This requires that we understand the phenotypic characteristics, such as gene expression patterns, of a particular brain cell type, so that we may determine how faithfully the iPS cell-derived cell recapitulates the in vivo version. Once we know the genetic identity of a natural cell, we can correlate this identity to our engineered cell in vitro. Strategies like this are already proposed within the retina (Siegert et al., 2012).

\section{Modeling neurological disease in three-dimensional culture systems}

In the previous section, we discussed the impact of distinct cell types in $\mathrm{AD}$ and what have been the current efforts in the field to generate different neural lineages from iPS cells. Although the analysis of a pure cell type population can give valuable insides into the biology of the cell, it is often the interaction between different cell types that are most important to a true model of neural systems: for example, neurons exhibit increased synapse formation when they are co-cultured with astrocytes (Pfrieger and Barres, 1997), and astrocytes may look and behave differently in two-dimensional culture than they do in the brain (Cahoy et al., 2008; Puschmann et al., 2013). The latter is a concern for all cell types, since neurons and glia both utilize subcellular specializations, or compartmentalization, to function properly in vivo (Khakh and McCarthy, 2015; Tonnesen et al., 2014). In a monolayer in a culture dish, some of this compartmentalization may be lost. One example is the observation of calcium microdomains in astrocytes in vivo and in slice preparations, in which specific subregions of the astrocytic arbor exhibit restricted calcium oscillations that may reflect activity to immediately adjacent neurons (Bernardinelli et al., 2014; Di Castro et al., 2011; Shigetomi 
et al., 2013). Another concern is that phenotypes of aberrant extracellular protein aggregation are lost in two-dimensional cultures simply due to the lack of interstitial compartment, and metabolites of interest may diffuse to the media. To overcome this, recent studies have embedded human ES or iPS cell-derived cells in scaffolding such as hydrogel or Matrigel, to create three dimensional culture systems (Pasca et al., 2015; Schwartz et al., 2015; Smith et al., 2015). These kinds of culture systems, when created with human cells overexpressing fAD proteins or treated with $A B$ oligomers, can recapitulate AD-like phenotypes such as extracellular A $\beta$ plaque-like deposits (Choi et al., 2014; Kim et al., 2015) and cytoskeletal abnormalities (F. Zhang et al., 2014; Y. Zhang et al., 2014; D. Zhang et al., 2014).

To address issues that might arise from overly simplistic culture model systems, a number of groups have taken advantage of tissue engineering approaches that can generate either scaffolded or selforganizing neural cytosystems, such as "organoids". In 2008, the Sasai laboratory demonstrated that mouse and human ES cells could form self-organized apico-basally polarized cortical tissue (Eiraku and Sasai, 2012; Eiraku et al., 2008). However this technique lacks the later stage of cortical development, namely, discrete cortical layer formation with the typically inside-out organization, as well as the presence of outer radial glia. Lancaster et al. (2013) improved the protocol and reported a model for human brain development in 3D organoid structure. They observed cortical-like neuronal generation and organization, and observed astrocytes and oligodendrocytes after more than 100 days in vitro. To date, AD-like phenotypes have not been reported in selforganizing three-dimensional cultures or organoids from patientderived cells. However, the three-dimensional cultures reported by Choi et al., which overexpressed mutant APP, also showed an increase in phospho-Tau levels, suggesting that it may be possible to recapitulate many AD phenotypes within one model system, which would be a strong advantage in comparison to AD mouse models (Choi et al., 2014; Kim et al., 2015). Three-dimensional neural culture systems have yet to recapitulate complex in vivo brain systems that include elements such as the blood-brain-barrier, vascularization, or immune response, which all have an important impact during disease and treatment. Therefore, multiple research groups are focusing on creating vascularization, as shown for liver tissue (Masumoto et al., 2014; Samuel et al., 2013; Takebe et al., 2013) or blood-brain-barrier structures from iPS cells (Lippmann et al., 2014; Lippmann et al., 2013; Lippmann et al., 2012; Minami et al., 2015).

\section{Conclusion}

In this review, we have outlined recent strategies to investigate AD pathology using human iPS cells and to find new therapeutic targets preventing disease onset and progression. The approval rate for $\mathrm{AD}$ medications is a scant $4 \%$ of all treatments that enter onto Phase I trials (McBride, 2012), while projections predict 13.8 million people with AD and \$1.2 trillion spent on AD-related care in the year 2050 (Association, 2013; Hebert et al., 2013). These numbers clearly show that new model systems are needed to better translate observations from rodent models into clinical studies. Human iPS cells will be an important step forward in this direction; they have the potential to recapitulate phenotypes from various neurological diseases in a cell type-specific manner. Creating isogenic iPS cell lines overcome problems of variability in human genomes and genome-editing technology has become much easier to implement. We have outlined how iPS cells can model disease etiology, progression, and phenotypes in human AD. Several groups have, to date, succeeded in recapitulating multiple AD-like phenotypes in human iPS cells. Thus, the stage appears to be set for the widespread use of iPS cells in preclinical drug trials for AD therapies (reviewed in (Khurana et al., 2015)). To benefit most from these cellular models, it will be absolutely crucial that all experiments are performed in a controlled and standardized manner that will allow reproducibility between different research groups.
Several areas of iPS cell research remain topics of much debate or even controversy. For example, there is debate over exactly how similar iPS and ES cells are, and how well iPS cells can functionally replace ES cells in translational research (Bock et al., 2011; Chin et al., 2009; Doi et al., 2009; Hu et al., 2010; Narsinh et al., 2011a, 2011b). In addition to the ethical and legal issues that have arisen regarding the creation of ES cells, which hinder the production of new lines, a clear advantage of iPS cells is that the donor is often an adult, sometimes elderly, and thus can provide a health history relevant to the disorder of interest. This is not possible with ES cells. This said, the ability to access patient history in the use of iPS cell research is highly variable between research groups and subject to a great deal of regulation to ensure patient privacy (King and Perrin, 2014; Lomax et al., 2015; Lomax and Peckman, 2012; Lomax et al., 2013). As more and more iPS cell lines are characterized and this information added to public databases, we expect that even researchers without direct access to patient information will benefit from these models. The development of libraries of disease-associated iPS cell lines, of both genders, will allow high-throughput drug discovery and validation, and should make the rocky path from bench to clinic shorter and straighter.

In this review, we also put a strong focus on the impact of different cell types. It will be crucial to investigate the impact of drugs across different cell types. The use of three-dimensional scaffolding combined with differentiated cells (Choi et al., 2014), or the creation of selforganizing neural tissue structures in vitro (Eiraku and Sasai, 2012; Eiraku et al., 2008; Kadoshima et al., 2013; Lancaster et al., 2013; Lancaster and Knoblich, 2014), hold great promise for modeling the intricate micro- and macro-environment of the brain. In the future, it may be possible to screen drugs in these cytosystems, which have the benefit of containing multiple neural cell types in a physiological microenvironment and, with the development of vascularization technique, may include blood-brain barrier penetration in the assay at an early stage of drug discovery.

\section{Acknowledgments}

This work was supported by NIH grant R01-AG047661 to LHT. The art in Fig. 1 was created by Julian Wong.

\section{References}

Almeida, S., Zhang, Z., Coppola, G., Mao, W., Futai, K., Karydas, A., Geschwind, M.D., Tartaglia, M.C., Gao, F., Gianni, D., Sena-Esteves, M., Geschwind, D.H., Miller, B.L., Farese Jr., R.V., Gao, F.B., 2012. Induced pluripotent stem cell models of progranulindeficient frontotemporal dementia uncover specific reversible neuronal defects. Cell Rep. 2, 789-798. http://dx.doi.org/10.1016/j.celrep.2012.09.007 (PMID: 23063362).

Alzheimer, A., 1911. Über eigenartige Krankheitsfalle des späteren Alters. Zbl. ges. Neurol. Psychiatr. 4, 356-385.

Ando, K, Brion, J.P. Stygelbout V, Suain, V., Authelet, M., Dedecker, R., Chanut, A, Lacor, P., Lavaur, J., Sazdovitch, V., Rogaeva, E., Potier, M.C., Duyckaerts, C., 2013. Clathrin adaptor CALM/PICALM is associated with neurofibrillary tangles and is cleaved in Alzheimer's brains. Acta Neuropathol. 125, 861-878. http://dx.doi.org/10.1007/ s00401-013-1111-z PMID: 23589030.

Antunez, C., Boada, M., Gonzalez-Perez, A., Gayan, J., Ramirez-Lorca, R., Marin, J., Hernandez, I., Moreno-Rey, C., Moron, F.J., Lopez-Arrieta, J., Mauleon, A., RosendeRoca, M., Noguera-Perea, F., Legaz-Garcia, A., Vivancos-Moreau, L., Velasco, J., Carrasco, J.M., Alegret, M., Antequera-Torres, M., Manzanares, S., Romo, A., Blanca, I., Ruiz, S., Espinosa, A., Castano, S., Garcia, B., Martinez-Herrada, B., Vinyes, G., Lafuente, A., Becker, J.T., Galan, J.J., Serrano-Rios, M., Alzheimer's Disease Neuroimaging, I, Vazquez, E., Tarraga, L., Saez, M.E., Lopez, O.L., Real, L.M., Ruiz, A., 2011. The membrane-spanning 4-domains, subfamily A (MS4A) gene cluster contains a common variant associated with Alzheimer's disease. Genome Med. 3, 33. http://dx.doi.org/10.1186/gm249 (PMID: 21627779).

Association, A., 2013. 2013 Alzheimer's disease facts and figures. Alzheimer's \& dementia : the journal of the Alzheimer's Association 8, 131-168. http://dx.doi.org/10.1016/j. jalz.2012.02.001 (PMID: 22404854).

Ballatore, C., Lee, V.M.Y., Trojanowski, J.Q. 2007. Tau-mediated neurodegeneration in Alzheimer's disease and related disorders. Nat. Rev. Neurosci. 8, 663-672.

Bartos, M., Vida, I., Jonas, P., 2007. Synaptic mechanisms of synchronized gamma oscillations in inhibitory interneuron networks. Nat. Rev. Neurosci. 8, 45-56. http://dx.doi. org/10.1038/nrn2044 (PMID: 17180162).

Bartzokis, G., 2011. Alzheimer's disease as homeostatic responses to age-related myelin breakdown. Neurobiol. Aging 32, 1341-1371. http://dx.doi.org/10.1016/j. neurobiolaging.2009.08.007 (PMID: 19775776). 
Bercury, K.K., Macklin, W.B., 2015. Dynamics and mechanisms of CNS myelination. Dev. Cell 32, 447-458. http://dx.doi.org/10.1016/j.devcel.2015.01.016 (PMID: 25710531).

Bernardinelli, Y., Randall, J., Janett, E., Nikonenko, I., Konig, S., Jones, E.V., Flores, C.E., Murai, K.K., Bochet, C.G., Holtmaat, A., Muller, D., 2014. Activity-dependent structural plasticity of perisynaptic astrocytic domains promotes excitatory synapse stability. Curr. Biol. 24, 1679-1688. http://dx.doi.org/10.1016/j.cub.2014.06.025 (PMID: 25042585).

Bertram, L., Tanzi, R.E., 2008. Thirty years of Alzheimer's disease genetics: the implications of systematic meta-analyses. Nat. Rev. Neurosci. 9, 768-778.

Bertram, L., Lange, C., Mullin, K., Parkinson, M., Hsiao, M., Hogan, M.F., Schjeide, B.M., Hooli, B., Divito, J., Ionita, I., Jiang, H., Laird, N., Moscarillo, T., Ohlsen, K.L., Elliott, K., Wang, X., Hu-Lince, D., Ryder, M., Murphy, A., Wagner, S.L., Blacker, D., Becker, K.D., Tanzi, R.E., 2008. Genome-wide association analysis reveals putative Alzheimer's disease susceptibility loci in addition to APOE. Am. J. Hum. Genet. 83, 623-632. http://dx.doi.org/10.1016/j.ajhg.2008.10.008 (PMID: 18976728).

Bertram, L., McQueen, M.B., Mullin, K., Blacker, D., Tanzi, R.E., 2007. Systematic metaanalyses of Alzheimer disease genetic association studies: the AlzGene database. Nat. Genet. 39, 17-23. http://dx.doi.org/10.1038/ng1934 (PMID: 17192785).

Beutner, C., Linnartz-Gerlach, B., Schmidt, S.V., Beyer, M., Mallmann, M.R., Staratschek-Jox, A. Schultze, J.L., Neumann, H., 2013. Unique transcriptome signature of mouse microglia. Glia 61, 1429-1442. http://dx.doi.org/10.1002/glia.22524 (PMID: 23832717).

Beutner, C., Roy, K., Linnartz, B., Napoli, I., Neumann, H., 2010. Generation of microglial cells from mouse embryonic stem cells. Nat. Protoc. 5, 1481-1494. http://dx.doi. org/10.1038/nprot.2010.90 (PMID: 20725065).

Beyreuther, K., Pollwein, P., Multhaup, G., Monning, U., Konig, G., Dyrks, T., Schubert, W., Masters, C.L., 1993. Regulation and expression of the Alzheimer's beta/A4 amyloid protein precursor in health, disease, and Down's syndrome. Ann. N. Y. Acad. Sci. 695 (691-102, PMID: 8239320).

Biancotti, J.C., Narwani, K., Buehler, N., Mandefro, B., Golan-Lev, T., Yanuka, O., Clark, A., Hill, D., Benvenisty, N., Lavon, N., 2010. Human embryonic stem cells as models for aneuploid chromosomal syndromes. Stem Cells 28, 1530-1540 (20641042).

Blalock, E.M., Buechel, H.M., Popovic, J., Geddes, J.W., Landfield, P.W., 2011. Microarray analyses of laser-captured hippocampus reveal distinct gray and white matter signatures associated with incipient Alzheimer's disease. J. Chem. Neuroanat. 42, 118-126. http://dx.doi.org/10.1016/j.jchemneu.2011.06.007 (PMID: 21756998).

Blalock, E.M., Geddes, J.W., Chen, K.C., Porter, N.M., Markesbery, W.R., Landfield, P.W., 2004. Incipient Alzheimer's disease: microarray correlation analyses reveal major transcriptional and tumor suppressor responses. Proc. Natl. Acad. Sci. U. S. A. 101, 2173-2178. http://dx.doi.org/10.1073/pnas.0308512100 (PMID: 14769913).

Blennow, K., 2010. Biomarkers in alzheimer's disease drug development. Nat. Med. 16, 1218-1222. http://dx.doi.org/10.1038/nm.2221 (PMID: 21052077)

Blondel, S., Jaskowiak, A.L., Egesipe, A.L., Le Corf, A., Navarro, C., Cordette, V., Martinat, C., Laabi, Y., Djabali, K., de Sandre-Giovannoli, A., Levy, N., Peschanski, M., Nissan, X. 2014. Induced pluripotent stem cells reveal functional differences between drugs currently investigated in patients with Hutchinson-Gilford Progeria Syndrome. Stem Cells Transl. Med. 3, 510-519. http://dx.doi.org/10.5966/sctm.2013-0168 (PMID: 24598781).

Bock, C., Kiskinis, E., Verstappen, G., Gu, H., Boulting, G., Smith, Z.D., Ziller, M., Croft, G.F., Amoroso, M.W., Oakley, D.H., Gnirke, A., Eggan, K., Meissner, A., 2011. Reference maps of human ES and iPS cell variation enable high-throughput characterization of pluripotent cell lines. Cell 144, 439-452. http://dx.doi.org/10.1016/j.cell.2010.12. 032 (PMID: 21295703)

Bolmont, T., Haiss, F., Eicke, D., Radde, R., Mathis, C.A., Klunk, W.E., Kohsaka, S., Jucker, M., Calhoun, M.E., 2008. Dynamics of the microglial/amyloid interaction indicate a role in plaque maintenance. J. Neurosci. 28, 4283-4292. http://dx.doi.org/10.1523/jneurosci. 4814-07.2008 (PMID: 18417708)

Boulting, G.L., Kiskinis, E., Croft, G.F., Amoroso, M.W., Oakley, D.H., Wainger, B.J., Williams, D.J., Kahler, D.J., Yamaki, M., Davidow, L., Rodolfa, C.T., Dimos, J.T., Mikkilineni, S., MacDermott, A.B., Woolf, C.J., Henderson, C.E., Wichterle, H., Eggan, K., 2011. A functionally characterized test set of human induced pluripotent stem cells. Nat. Biotechnol. 29. http://dx.doi.org/10.1038/nbt.1783 (279-U147, PMID: 21293464).

Bouwman, B.A., de Laat, W., 2015. Architectural hallmarks of the pluripotent genome. FEBS Lett. http://dx.doi.org/10.1016/j.febslet.2015.04.055 (PMID: 25957773).

Braak, H., Braak, E., 1991. Neuropathological stageing of Alzheimer-related changes. Acta Neuropathol. 82, 239-259 (PMID: 1759558).

Bradshaw, E.M., Chibnik, L.B., Keenan, B.T., Ottoboni, L., Raj, T., Tang, A., Rosenkrantz, L.L. Imboywa, S., Lee, M., Von Korff, A., Morris, M.C., Evans, D.A., Johnson, K., Sperling, R.A., Schneider, J.A., Bennett, D.A., De Jager, P.L., 2013. CD33 Alzheimer's disease locus: altered monocyte function and amyloid biology. Nat. Neurosci. 16, 848-850. http:// dx.doi.org/10.1038/nn.3435.

Brennand, K.J., Simone, A., Jou, J., Gelboin-Burkhart, C., Tran, N., Sangar, S., Li, Y., Mu, Y., Chen, G., Yu, D., McCarthy, S., Sebat, J., Gage, F.H., 2011. Modelling schizophrenia using human induced pluripotent stem cells. Nature 473, 221-225. http://dx.doi. org/10.1038/nature09915 (PMID: 21490598).

Bribian, A., Figueres-Onate, M., Martin-Lopez, E., Lopez-Mascaraque, L., 2015. Decoding astrocyte heterogeneity: new tools for clonal analysis. Neuroscience http://dx.doi. org/10.1016/j.neuroscience.2015.04.036 (PMID: 25917835).

Broccoli, V., Giannelli, S.G., Mazzara, P.G., 2014. Modeling physiological and pathological human neurogenesis in the dish. Front. Neurosci. 8, 183. http://dx.doi.org/10.3389/ fnins.2014.00183 (PMID: 25104921)

Broccoli, V., Rubio, A., Taverna, S., Yekhlef, L., 2015. Overcoming the hurdles for a reproducible generation of human functionally mature reprogrammed neurons. Exp. Biol. Med. (Maywood) 240, 787-794. http://dx.doi.org/10.1177/1535370215577585 (PMID: 25790823)

Bu, G., 2009. Apolipoprotein E and its receptors in Alzheimer's disease: pathways, pathogenesis and therapy. Nat. Rev. Neurosci. 10, 333-344. http://dx.doi.org/10.1038/ nrn2620 (PMID: 19339974).
Burger, P.C., Vogel, F.S., 1973. The development of the pathologic changes of Alzheimer's disease and senile dementia in patients with Down's syndrome. Am. J. Pathol. 73, 457-476 (PMID: 4271339)

Byrne, S.M., Mali, P., Church, G.M., 2014. Genome editing in human stem cells. Methods Enzymol. 546, 119-138. http://dx.doi.org/10.1016/B978-0-12-801185-0.00006-4 (PMID: 25398338)

Cahoy, J.D., Emery, B., Kaushal, A., Foo, L.C., Zamanian, J.L., Christopherson, K.S., Xing, Y., Lubischer, J.L., Krieg, P.A., Krupenko, S.A., Thompson, W.J., Barres, B.A., 2008. A transcriptome database for astrocytes, neurons, and oligodendrocytes: a new resource for understanding brain development and function. J. Neurosci. 28, 264-278. http:// dx.doi.org/10.1523/JNEUROSCI.4178-07.2008 (PMID: 18171944).

Caiazzo, M., Giannelli, S., Valente, P., Lignani, G., Carissimo, A., Sessa, A., Colasante, G. Bartolomeo, R., Massimino, L., Ferroni, S., Settembre, C., Benfenati, F., Broccoli, V., 2015. Direct conversion of fibroblasts into functional astrocytes by defined transcription factors. Stem Cell Rep. 4, 25-36. http://dx.doi.org/10.1016/j.stemcr.2014.12.002 (PMID: 25556566)

Calero, M., Rostagno, A., Matsubara, E., Zlokovic, B., Frangione, B., Ghiso, J., 2000. Apolipoprotein J (clusterin) and Alzheimer's disease. Microsc. Res. Tech. 50, 305-315. http:// dx.doi.org/10.1002/1097-0029(20000815)50:4<305::AID-JEMT10>3.0.CO;2-L (PMID: 10936885).

Carroll, D., 2011. Genome engineering with zinc-finger nucleases. Genetics 188, 773-782 http://dx.doi.org/10.1534/genetics.111.131433 (PMID: 21828278).

Castellano, J.M., Kim, J., Stewart, F.R., Jiang, H., DeMattos, R.B., Patterson, B.W., Fagan, A.M., Morris, J.C., Mawuenyega, K.G., Cruchaga, C., Goate, A.M., Bales, K.R., Paul, S.M., Bateman, R.J., Holtzman, D.M., 2011. Human apoE isoforms differentially regulate brain amyloid- $\beta$ peptide clearance. Sci. Transl. Med. 3 .

Cataldo, A., Rebeck, G.W., Ghetri, B., Hulette, C., Lippa, C., Van Broeckhoven, C., van Duijn C., Cras, P., Bogdanovic, N., Bird, T., Peterhoff, C., Nixon, R., 2001. Endocytic disturbances distinguish among subtypes of Alzheimer's disease and related disorders. Ann. Neurol. 50, 661-665 (PMID: 11706973)

Cataldo, A.M., Mathews, P.M., Boiteau, A.B., Hassinger, L.C., Peterhoff, C.M., Jiang, Y., Mullaney, K., Neve, R.L., Gruenberg, J., Nixon, R.A., 2008. Down syndrome fibroblast model of Alzheimer-related endosome pathology: accelerated endocytosis promotes late endocytic defects. Am. J. Pathol. 173, 370-384. http://dx.doi.org/10.2353/ajpath. 2008.071053 (PMID: 18535180).

Cataldo, A.M., Peterhoff, C.M., Troncoso, J.C., Gomez-Isla, T., Hyman, B.T., Nixon, R.A., 2000 Endocytic pathway abnormalities precede amyloid $\beta$ deposition in sporadic alzheimer's disease and down syndrome: differential effects of APOE genotype and presenilin mutations. Am. J. Pathol. 157, 277-286.

Chang, C.Y., Chen, S.M., Lu, H.E., Lai, S.M., Lai, P.S., Shen, P.W., Chen, P.Y., Shen, C.I., Harn, H.J., Lin, S.Z., Hwang, S.M., Su, H.L., 2015. N-butylidenephthalide attenuates Alzheimer's disease-like cytopathy in Down syndrome induced pluripotent stem cell-derived neurons. Sci. Rep. 5, 8744. http://dx.doi.org/10.1038/srep08744 (PMID: 25735452).

Chen, C., Jiang, P., Xue, H., Peterson, S.E., Tran, H.T., McCann, A.E., Parast, M.M., Li, S., Pleasure, D.E., Laurent, L.C., Loring, J.F., Liu, Y., Deng, W., 2014. Role of astroglia in Down's syndrome revealed by patient-derived human-induced pluripotent stem cells. Nat. Commun. 5, 4430. http://dx.doi.org/10.1038/ncomms5430 (PMID: 25034944).

Chiba, K., Hockemeyer, D., 2015. Genome editing in human pluripotent stem cells using site-specific nucleases. second ed.Chromosomal Mutagenesis 1239, pp. 267-280 http://dx.doi.org/10.1007/978-1-4939-1862-1 15 (PMID: 25408412)

Chin, M.H., Mason, M.J., Xie, W., Volinia, S., Singer, M., Peterson, C., Ambartsumyan, G. Aimiuwu, O., Richter, L., Zhang, J., Khvorostov, I., Ott, V., Grunstein, M., Lavon, N., Benvenisty, N., Croce, C.M., Clark, A.T., Baxter, T., Pyle, A.D., Teitell, M.A., Pelegrini, M., Plath, K., Lowry, W.E., 2009. Induced pluripotent stem cells and embryonic stem cells are distinguished by gene expression signatures. Cell Stem Cell 5, 111-123. http://dx.doi.org/10.1016/j.stem.2009.06.008 ([pii]S1934-5909(09)00292-6. PMID: 19570518).

Chinchalongporn, V., Koppensteiner, P., Pre, D., Thangnipon, W., Bilo, L., Arancio, O., 2015 Connectivity and circuitry in a dish versus in a brain. Alzheimers Res. Ther. 7, 44 http://dx.doi.org/10.1186/s13195-015-0129-y (PMID: 26045718).

Choi, S.H., Kim, Y.H., Hebisch, M., Sliwinski, C., Lee, S., D'Avanzo, C., Chen, H., Hooli, B. Asselin, C., Muffat, J., Klee, J.B., Zhang, C., Wainger, B.J., Peitz, M., Kovacs, D.M., Woolf, C.J., Wagner, S.L., Tanzi, R.E., Kim, D.Y., 2014. A three-dimensional human neural cell culture model of Alzheimer's disease. Nature 515, 274-278. http://dx.doi.org/ 10.1038/nature13800 (PMID: 25307057).

Chung, C.Y., Khurana, V., Auluck, P.K., Tardiff, D.F., Mazzulli, J.R., Soldner, F., Baru, V., Lou, Y., Freyzon, Y., Cho, S., Mungenast, A.E., Muffat, J., Mitalipova, M., Pluth, M.D., Jui, N.T., Schule, B., Lippard, S.J., Tsai, L.H., Krainc, D., Buchwald, S.L., Jaenisch, R., Lindquist, S., 2013. Identification and rescue of alpha-synuclein toxicity in Parkinson patient-derived neurons. Science 342, 983-987. http://dx.doi.org/10.1126/science. 1245296 (PMID: 24158904).

Consortium, HDi, 2012. Induced pluripotent stem cells from patients with Huntington's disease show CAG-repeat-expansion-associated phenotypes. Cell Stem Cell 11 264-278. http://dx.doi.org/10.1016/j.stem.2012.04.027 (PMID: 22748968).

Corder, E.H., Saunders, A.M., Strittmatter, W.J., Schmechel, D.E., Gaskell, P.C., Small, G.W. Roses, A.D., Haines, J.L., Pericak-Vance, M.A., 1993. Gene dose of apolipoprotein E type 4 allele and the risk of Alzheimer's disease in late onset families. Science 261 921-923.

Corneveaux, J.J., Myers, A.J., Allen, A.N., Pruzin, J.J., Ramirez, M., Engel, A., Nalls, M.A., Chen, K., Lee, W., Chewning, K., Villa, S.E., Meechoovet, H.B., Gerber, J.D., Frost, D., Benson, H.L., O'Reilly, S., Chibnik, L.B., Shulman, J.M., Singleton, A.B., Craig, D.W., Van Keuren-Jensen, K.R., Dunckley, T., Bennett, D.A., De Jager, P.L., Heward, C., Hardy, J, Reiman, E.M., Huentelman, M.J., 2010. Association of CR1, CLU and PICALM with Alzheimer's disease in a cohort of clinically characterized and neuropathologically verified individuals. Hum. Mol. Genet. 19, 3295-3301. http://dx.doi.org/10.1093/ hmg/ddq221 (PMID: 20534741). 
Cowan, C.A., Atienza, J., Melton, D.A., Eggan, K., 2005. Nuclear reprogramming of somatic cells after fusion with human embryonic stem cells. Science 309, 1369-1373. http:// dx.doi.org/10.1126/science.1116447 (PMID: 16123299).

Crehan, H., Hardy, J., Pocock, J., 2013. Blockage of CR1 prevents activation of rodent microglia. Neurobiol. Dis. 54, 139-149. http://dx.doi.org/10.1016/j.nbd.2013.02.003 (PMID: 23454195).

Dabir, D.V., Robinson, M.B., Swanson, E., Zhang, B., Trojanowski, J.Q., Lee, V.M., Forman, M.S., 2006. Impaired glutamate transport in a mouse model of tau pathology in astrocytes. J. Neurosci. 26, 644-654. http://dx.doi.org/10.1523/JNEUROSCI.3861-05. 2006 (PMID: 16407562)

De Strooper, B., 2010. Proteases and proteolysis in Alzheimer disease: a multifactoria view on the disease process. Physiol. Rev. 90, 465-494. http://dx.doi.org/10.1152/ physrev.00023.2009 (PMID: 20393191)

DeFelipe, J., Lopez-Cruz, P.L., Benavides-Piccione, R., Bielza, C., Larranaga, P., Anderson, S., Burkhalter, A., Cauli, B., Fairen, A., Feldmeyer, D., Fishell, G., Fitzpatrick, D., Freund, T.F., Gonzalez-Burgos, G., Hestrin, S., Hill, S., Hof, P.R., Huang, J., Jones, E.G., Kawaguchi, Y., Kisvarday, Z., Kubota, Y., Lewis, D.A., Marin, O., Markram, H., McBain, C.J., Meyer, H.S. Monyer, H., Nelson, S.B., Rockland, K., Rossier, J., Rubenstein, J.L.R., Rudy, B., Scanziani, M., Shepherd, G.M., Sherwood, C.C., Staiger, J.F., Tamas, G., Thomson, A., Wang, Y., Yuste, R., Ascoli, G.A., 2013. New insights into the classification and nomenclature of cortical GABAergic interneurons. Nat. Rev. Neurosci. 14, 202-216. http://dx.doi. org/10.1038/nrn3444 (PMID: 23385869).

Deng, Y.L., Liu, L.H., Wang, Y., Tang, H.D., Ren, R.J., Xu, W., Ma, J.F., Wang, L.L., Zhuang, J.P., Wang, G., Chen, S.D., 2012. The prevalence of CD33 and MS4A6A variant in Chinese Han population with Alzheimer's disease. Hum. Genet. 131, 1245-1249. http://dx. doi.org/10.1007/s00439-012-1154-6 (PMID: 22382309).

Denham, M., Dottori, M., 2011. Neural differentiation of induced pluripotent stem cells. Neurodegeneration Meth. Protoc. 793, 99-110. http://dx.doi.org/10.1007/978-1 61779-328-8 7 (PMID: 21913096).

Desai, M.K., Mastrangelo, M.A., Ryan, D.A., Sudol, K.L., Narrow, W.C., Bowers, W.J., 2010 Early oligodendrocyte/myelin pathology in Alzheimer's disease mice constitutes a novel therapeutic target. Am. J. Pathol. 177, 1422-1435. http://dx.doi.org/10.2353/ ajpath.2010.100087 (PMID: 20696774).

Desai, M.K., Sudol, K.L., Janelsins, M.C., Mastrangelo, M.A., Frazer, M.E., Bowers, W.J., 2009 Triple-transgenic Alzheimer's disease mice exhibit region-specific abnormalities in brain myelination patterns prior to appearance of amyloid and tau pathology. Glia 57, 54-65. http://dx.doi.org/10.1002/glia.20734 (PMID: 18661556).

Di Castro, M.A., Chuquet, J., Liaudet, N., Bhaukaurally, K., Santello, M., Bouvier, D., Tiret, P., Volterra, A., 2011. Local $\mathrm{Ca}^{2+}$ detection and modulation of synaptic release by astrocytes. Nat. Neurosci. 14, 1276-1284. http://dx.doi.org/10.1038/nn.2929 (PMID: 21909085)

Dimos, J.T., Rodolfa, K.T., Niakan, K.K., Weisenthal, L.M., Mitsumoto, H., Chung, W., Croft, G.F., Saphier, G., Leibel, R., Goland, R., Wichterle, H., Henderson, C.E., Eggan, K. 2008. Induced pluripotent stem cells generated from patients with ALS can be differentiated into motor neurons. Science 321, 1218-1221. http://dx.doi.org/10. 1126/science ([pii]: 1158799.1158799 PMID: 18669821).

Ding, Q., Lee, Y.-K., Schaefer, E.A.K., Peters, D.T., Veres, A., Kim, K., Kuperwasser, N., Motola, D.L., Meissner, T.B., Hendriks, W.T., Trevisan, M., Gupta, R.M., Moisan, A., Banks, E., Friesen, M., Schinzel, R.T., Xia, F., Tang, A., Xia, Y., Figueroa, E., Wann, A., Ahfeldt, T. Daheron, L., Zhang, F., Rubin, L.L., Peng, L.F., Chung, R.T., Musunuru, K., Cowan, C.A. 2013a. A TALEN genome-editing system for generating human stem cell-based disease models. Cell Stem Cell 12, 238-251. http://dx.doi.org/10.1016/j.stem.2012. 11.011 (PMID: 23246482)

Ding, O., Regan, S.N., Xia, Y., Oostrom, L.A., Cowan, C.A., Musunuru, K., 2013b. Enhanced efficiency of human pluripotent stem cell genome editing through replacing TALENs with CRISPRs. Cell Stem Cell 12, 393-394. http://dx.doi.org/10.1016/j.stem.2013.03. 006 (PMID: 23561441).

Dobbin, M.M., Madabhushi, R., Pan, L., Chen, Y., Kim, D., Gao, J., Ahononu, B., Pao, P.C., Qiu, Y., Zhao, Y., Tsai, L.H., 2013. SIRT1 collaborates with ATM and HDAC1 to maintain genomic stability in neurons. Nat. Neurosci. http://dx.doi.org/10.1038/nn.3460 ([pii]: nn.3460. PMID: 23852118).

Doi, A., Park, I.H., Wen, B., Murakami, P., Aryee, M.J., Irizarry, R., Herb, B., Ladd-Acosta, C., Rho, J., Loewer, S., Miller, J., Schlaeger, T., Daley, G.Q., Feinberg, A.P., 2009 Differential methylation of tissue- and cancer-specific CpG island shores distinguishes human induced pluripotent stem cells, embryonic stem cells and fibroblasts. Nat. Genet. 41, 1350-1353. http://dx.doi.org/10.1038/ng.471.[pii].ng.471 (PMID: 19881528)

Doody, R.S., Raman, R., Farlow, M., Iwatsubo, T., Vellas, B., Joffe, S., Kieburtz, K., He, F., Sun, X., Thomas, R.G., Aisen, P.S., Alzheimer's Disease Cooperative Study Steering, C Siemers, E., Sethuraman, G., Mohs, R., Semagacestat Study, G., 2013. A phase 3 trial of semagacestat for treatment of Alzheimer's disease. N. Engl. J. Med. 369, 341-350. http://dx.doi.org/10.1056/NEJMoa1210951 (PMID: 23883379).

Doody, R.S., Thomas, R.G., Farlow, M., Iwatsubo, T., Vellas, B., Joffe, S., Kieburtz, K., Raman, R., Sun, X., Aisen, P.S., Siemers, E., Liu-Seifert, H., Mohs, R., Alzheimer's Disease Cooperative Study Steering C, Solanezumab Study, G, 2014. Phase 3 trials of solanezumab for mild-to-moderate Alzheimer's disease. N. Engl. J. Med. 370, 311-321. http://dx.doi.org/10.1056/NEJMoa1312889 (PMID: 24450890).

Douvaras, P., Wang, J. Zimmer, M., Hanchuk, S., O'Bara, M.A., Sadiq, S., Sim, F.., Goldman, J., Fossati, V., 2014. Efficient generation of myelinating oligodendrocytes from primary progressive multiple sclerosis patients by induced pluripotent stem cells. Stem Cell Rep. 3, 250-259. http://dx.doi.org/10.1016/j.stemcr.2014.06.012 (PMID: 25254339).

Ebert, A.D., Yu, J., Rose Jr., F.F., Mattis, V.B., Lorson, C.L., Thomson, J.A., Svendsen, C.N., 2009. Induced pluripotent stem cells from a spinal muscular atrophy patient. Nature 457 277-280. http://dx.doi.org/10.1038/nature07677 ([pii] nature07677. PMID: 19098894).
Editorial, 2013. Strengthening connections between Down syndrome and AD. Lancet Neurol. 12, 931. http://dx.doi.org/10.1016/S1474-4422(13)70228-X (PMID: 24050729)

Eiraku, M., Sasai, Y., 2012. Self-formation of layered neural structures in threedimensional culture of ES cells. Curr. Opin. Neurobiol. 22, 768-777. http://dx.doi. org/10.1016/j.conb.2012.02.005 (PMID: 22405989).

Eiraku, M., Watanabe, K., Matsuo-Takasaki, M., Kawada, M., Yonemura, S., Matsumura, M., Wataya, T., Nishiyama, A., Muguruma, K., Sasai, Y., 2008. Self-organized formation of polarized cortical tissues from ESCs and its active manipulation by extrinsic signals. Cell Stem Cell 3, 519-532. http://dx.doi.org/10.1016/j.stem.2008.09.002 (PMID: 18983967)

Englund, E., Brun, A., Alling, C., 1988. White matter changes in dementia of Alzheimer's type. Biochemical and neuropathological correlates. Brain 111 (Pt 6), 1425-1439 (PMID: 3208064)

Espuny-Camacho, I., Michelsen, K.A., Gall, D., Linaro, D., Hasche, A., Bonnefont, J., Bali, C., Orduz, D., Bilheu, A., Herpoel, A., Lambert, N., Gaspard, N., Peron, S., Schiffmann, S.N., Giugliano, M., Gaillard, A., Vanderhaeghen, P., 2013. Pyramidal neurons derived from human pluripotent stem cells integrate efficiently into mouse brain circuits in vivo. Neuron 77, 440-456. http://dx.doi.org/10.1016/j.neuron.2012.12.011 (PMID: 23395372)

Etemad, S., Zamin, R.M., Ruitenberg, M.J., Filgueira, L., 2012. A novel in vitro human microglia model: characterization of human monocyte-derived microglia. J. Neurosci. Methods 209, 79-89. http://dx.doi.org/10.1016/j.jneumeth.2012.05.025 (PMID: 22659341).

Evans, M.J., Kaufman, M.H., 1981. Establishment in culture of pluripotential cells from mouse embryos. Nature 292, 154-156. http://dx.doi.org/10.1038/292154a0 (PMID: 7242681).

Falk, A., Koch, P., Kesavan, J., Takashima, Y., Ladewig, J., Alexander, M., Wiskow, O., Tailor, J. Trotter M. Pollard, S, Smith, A., Brustle, O., 2012. Capture of neuroepithelial-like stem cells from pluripotent stem cells provides a versatile system for in vitro production of human neurons. PLoS One 7, e29597 (22272239)

Farrer, L.A., Cupples, L.A., Haines, J.L., Hyman, B., Kukull, W.A., Mayeux, R., Myers, R.H., Pericak-Vance, M.A., Risch, N., van Duijn, C.M., 1997. Effects of age, sex, and ethnicity on the association between apolipoprotein E genotype and Alzheimer disease. A meta-analysis. APOE and Alzheimer Disease Meta Analysis Consortium. JAMA (PMID: 9343467)

Fischer, A., Sananbenesi, F., Pang, P.T., Lu, B., Tsai, L.H., 2005. Opposing roles of transient and prolonged expression of p25 in synaptic plasticity and hippocampusdependent memory. Neuron 48, 825-838.

Fishell, G., Heintz, N., 2013. The neuron identity problem: form meets function. Neuron 80, 602-612. http://dx.doi.org/10.1016/j.neuron.2013.10.035 (PMID: 24183013).

Fong, H., Wang, C., Knoferle, J., Walker, D., Balestra, M.E., Tong, L.M., Leung, L., Ring, K.L., Seeley, W.W., Karydas, A., Kshirsagar, M.A., Boxer, A.L., Kosik, K.S., Miller, B.L., Huang, Y., 2013. Genetic correction of tauopathy phenotypes in neurons derived from human induced pluripotent stem cells. Stem Cell Rep. 1, 226-234. http://dx. doi.org/10.1016/j.stemcr.2013.08.001 (PMID: 24319659).

Foo, L.C., Allen, N.J., Bushong, E.A., Ventura, P.B., Chung, W.S., Zhou, L., Cahoy, J.D. Daneman, R., Zong, H., Ellisman, M.H., Barres, B.A., 2011. Development of a method for the purification and culture of rodent astrocytes. Neuron 71, 799-811. http://dx. doi.org/10.1016/j.neuron.2011.07.022 (PMID: 21903074).

Fryer, J.D., Simmons, K., Parsadanian, M., Bales, K.R., Paul, S.M., Sullivan, P.M., Holtzman, D.M., 2005. Human apolipoprotein E4 alters the amyloid- $\beta$ 40:42 ratio and promotes the formation of cerebral amyloid angiopathy in an amyloid precursor protein transgenic model. J. Neurosci. 25, 2803-2810.

Gatz, M., Reynolds, C.A., Fratiglioni, L., Johansson, B., Mortimer, J.A., Berg, S., Fiske, A., Pedersen, N.L., 2006. Role of genes and environments for explaining Alzheimer disease. Arch. Gen. Psychiatry 63, 168-174. http://dx.doi.org/10.1001/archpsyc.63.2. 168 (PMID: 16461860)

Ginhoux, F., Greter, M., Leboeuf, M., Nandi, S., See, P., Gokhan, S., Mehler, M.F., Conway, S.J., Ng, L.G., Stanley, E.R., Samokhvalov, I.M., Merad, M., 2010. Fate mapping analysis reveals that adult microglia derive from primitive macrophages. Science 330 841-845 (PMID: 20966214).

Gjoneska, E., Pfenning, A.R., Mathys, H., Quon, G., Kundaje, A., Tsai, L.H., Kellis, M., 2015. Conserved epigenomic signals in mice and humans reveal immune basis of Alzheimer's disease. Nature 518, 365-369. http://dx.doi.org/10.1038/nature14252 (PMID: 25693568).

Glenner, G.G., Wong, C.W., 1984. Alzheimer's disease: initial report of the purification and characterization of a novel cerebrovascular amyloid protein. Biochem. Biophys. Res. Commun. 120, 885-890.

Goate, A., 2006. Segregation of a missense mutation in the amyloid beta-protein precursor gene with familial Alzheimer's disease. J. Alzheimers Dis. 9, 341-347 (PMID: 16914872)

Goate, A., Chartier-Harlin, M.-C., Mullan, M., Brown, J., Crawford, F., Fidani, L., Giuffra, L., Haynes, A., Irving, N., James, L., Mant, R., Newton, P., Rooke, K., Roques, P., Talbot, C., Pericak-Vance, M., Roses, A., Williamson, R., Rossor, M., Owen, M., Hardy, J., 1991. Segregation of a missense mutation in the amyloid precursor protein gene with familial Alzheimer's disease. Nature 349, 704-706.

Goldgaber, D., Lerman, M.I., McBride, W.O., Saffiotti, U., Gajdusek, D.C., 1987. Isolation, characterization, and chromosomal localization of human brain cDNA clones coding for the precursor of the amyloid of brain in Alzheimer's disease, Down's syndrome and aging. J. Neural Transm. Suppl. 24, 23-28 (PMID: 2960782).

Goto, M., 1997. Hierarchical deterioration of body systems in Werner's syndrome: implications for normal ageing. Mech. Ageing Dev. 98, 239-254.

Götz, J., Deters, N., Doldissen, A., Bokhari, L., Ke, Y., Wiesner, A., Schonrock, N., Ittner, L.M., 2007. A decade of tau transgenic animal models and beyond. Brain Pathol. 17, 91-103. http://dx.doi.org/10.1111/j.1750-3639.2007.00051.x. 
Graeber, M.B., Kosel, S., Egensperger, R., Banati, R.B., Muller, U., Bise, K., Hoff, P., Moller H.J., Fujisawa, K., Mehraein, P., 1997. Rediscovery of the case described by Alois Alzheimer in 1911: historical, histological and molecular genetic analysis. Neurogenetics 1, 73-80 (PMID: 10735278)

Grange, P., Bohland, J.W., Okaty, B.W., Sugino, K., Bokil, H., Nelson, S.B., Ng, L., Hawrylycz, M., Mitra, P.P., 2014. Cell-type-based model explaining coexpression patterns of genes in the brain. Proc. Natl. Acad. Sci. U. S. A. 111, 5397-5402. http://dx.doi.org/ 10.1073/pnas.1312098111 (PMID: 24706869).

Grundke-Iqbal, I., Iqbal, K., Quinlan, M., Tung, Y.C., Zaidi, M.S., Wisniewski, H.M., 1986. Microtubule-associated protein tau. A component of Alzheimer paired helical filaments. J. Biol. Chem. 261, 6084-6089 (PMID: 3084478)

Guerreiro, R., Wojtas, A., Bras, J., Carrasquillo, M., Rogaeva, E., Majounie, E., Cruchaga, C., Sassi, C., Kauwe, J.S., Younkin, S., Hazrati, L., Collinge, J., Pocock, J., Lashley, T., Williams, J., Lambert, J.C., Amouyel, P., Goate, A., Rademakers, R., Morgan, K., Powell, J., St George-Hyslop, P., Singleton, A., Hardy, J., Alzheimer Genetic Analysis, G., 2013. TREM2 variants in Alzheimer's disease. N. Engl. J. Med. 368, 117-127. http://dx.doi.org/10.1056/NEJMoa1211851 (PMID: 23150934).

Hanna, J.H., Saha, K., Jaenisch, R., 2010. Pluripotency and cellular reprogramming: facts, hypotheses, unresolved issues. Cell 143, 508-525. http://dx.doi.org/10.1016/j.cell. 2010.10.008 (PMID: 21074044)

Harold, D., Abraham, R., Hollingworth, P., Sims, R., Gerrish, A., Hamshere, M.L., Pahwa, J.S. Moskvina, V., Dowzell, K., Williams, A., Jones, N., Thomas, C., Stretton, A., Morgan, A.R. Lovestone, S., Powell, J., Proitsi, P., Lupton, M.K., Brayne, C., Rubinsztein, D.C., Gill, M. Lawlor, B., Lynch, A., Morgan, K., Brown, K.S., Passmore, P.A., Craig, D., McGuinness, B. Todd, S., Holmes, C., Mann, D., Smith, A.D., Love, S., Kehoe, P.G., Hardy, J., Mead, S., Fox, N., Rossor, M., Collinge, J., Maier, W., Jessen, F., Schurmann, B., van den Bussche, H. Heuser, I., Kornhuber, J., Wiltfang, J., Dichgans, M., Frolich, L., Hampel, H., Hull, M., Rujescu, D., Goate, A.M., Kauwe, J.S.K., Cruchaga, C., Nowotny, P., Morris, J.C., Mayo, K., Sleegers, K., Bettens, K., Engelborghs, S., De Deyn, P.P., Van Broeckhoven, C., Livingston, G., Bass, N.J., Gurling, H., McQuillin, A., Gwilliam, R., Deloukas, P., AlChalabi, A., Shaw, C.E., Tsolaki, M., Singleton, A.B., Guerreiro, R., Muhleisen, T.W. Nothen, M.M., Moebus, S., Jockel, K.-H., Klopp, N., Wichmann, H.E., Carrasquillo, M.M., Pankratz, V.S., Younkin, S.G., Holmans, P.A., O'Donovan, M., Owen, M.J., Williams, J., 2009. Genome-wide association study identifies variants at CLU and PICALM associated with Alzheimer's disease. Nat. Genet. 41, 1088-1093 (doi: http://www.nature.com/ng/journal/v41/n10/suppinfo/ng.440_S1.html).

Hasty, P., Campisi, J., Hoeijmakers, J., van Steeg, H., Vijg, J., 2003. Aging and genome maintenance: lessons from the mouse? Science 299, 1355-1359. http://dx.doi.org/10. 1126/science.1079161.

Haydon, P.G., Nedergaard, M., 2015. How do astrocytes participate in neural plasticity? Cold Spring Harb. Perspect. Biol. 7, a020438. http://dx.doi.org/10.1101/cshperspect. a020438 (PMID: 25502516).

Hazra, A., Gu, F., Aulakh, A., Berridge, C., Eriksen, J.L., Ziburkus, J., 2013. Inhibitory neuron and hippocampal circuit dysfunction in an aged mouse model of Alzheimer's disease. PLoS One 8, e64318. http://dx.doi.org/10.1371/journal.pone.0064318 (PMID: 23691195)

Hebert, L.E., Weuve, J., Scherr, P., Evans, D., 2013. Alzheimer disease in the United States (2010-2050) estimated using the 2010 census. Neurology http://dx.doi.org/10. 1212/WNL.0b013e31828726f5 (PMID: 23390181).

Hertz, L., Peng, L., Lai, J.C., 1998. Functional studies in cultured astrocytes. Methods 16 293-310. http://dx.doi.org/10.1006/meth.1998.0686 (PMID: 10071068).

Hibaoui, Y., Grad, I., Letourneau, A., Sailani, M.R., Dahoun, S., Santoni, F.A., Gimelli, S. Guipponi, M., Pelte, M.F., Bena, F., Antonarakis, S.E., Feki, A., 2014. Modelling and rescuing neurodevelopmental defect of Down syndrome using induced pluripotent stem cells from monozygotic twins discordant for trisomy 21. EMBO Mol. Med. 6 259-277. http://dx.doi.org/10.1002/emmm.201302848 (PMID: 24375627).

Hockemeyer, D., Soldner, F., Beard, C., Gao, Q., Mitalipova, M., DeKelver, R.C., Katibah, G.E., Amora, R., Boydston, E.A., Zeitler, B., Meng, X., Miller, J.C., Zhang, L., Rebar, E.J., Gregory, P.D., Urnov, F.D., Jaenisch, R., 2009. Efficient targeting of expressed and silent genes in human ESCs and iPSCs using zinc-finger nucleases. Nat. Biotechnol. 27, 851-857. http://dx.doi.org/10.1038/nbt.1562 (PMID: 19680244).

Hockemeyer, D., Wang, H., Kiani, S., Lai, C.S., Gao, Q., Cassady, J.P., Cost, G.J., Zhang, L., Santiago, Y., Miller, J.C., Zeitler, B., Cherone, J.M., Meng, X., Hinkley, S.J., Rebar, E.J., Gregory, P.D., Urnov, F.D., Jaenisch, R., 2011. Genetic engineering of human pluripotent cells using TALE nucleases. Nat. Biotechnol. 29, 731-734. http://dx.doi. org/10.1038/nbt.1927 (PMID: 21738127).

Hollingworth, P, Harold, D, Sims, R, Gerrish, A, Lambert, JC, Carrasquillo, MM, Abraham, R, Hamshere, ML, Pahwa, JS, Moskvina, V, Dowzell, K, Jones, N, Stretton, A, Thomas, C, Richards, A, Ivanov, D, Widdowson, C, Chapman, J, Lovestone, S, Powell, J, Proitsi, P, Lupton, MK, Brayne, C, Rubinsztein, DC, Gill, M, Lawlor, B, Lynch, A, Brown, KS, Passmore, PA, Craig, D, McGuinness, B, Todd, S, Holmes, C, Mann, D, Smith, AD Beaumont, H, Warden, D, Wilcock, G, Love, S, Kehoe, PG, Hooper, NM, Vardy, ER, Hardy, J, Mead, S, Fox, NC, Rossor, M, Collinge, J, Maier, W, Jessen, F, Ruther, E, Schurmann, B, Heun, R, Kolsch, H, van den Bussche, H, Heuser, I, Kornhuber, J, Wiltfang, J, Dichgans, M, Frolich, L, Hampel, H, Gallacher, J, Hull, M, Rujescu, D, Giegling, I, Goate, AM, Kauwe, IS, Cruchaga, C, Nowotny, P, Morris, JC, Mayo, K, Sleegers, K, Bettens, K, Engelborghs, S, De Deyn, PP, Van Broeckhoven, C, Livingston, G, Bass, NJ, Gurling, H, McQuillin, A, Gwilliam, R, Deloukas, P, Al-Chalabi, A, Shaw, CE, Tsolaki, M, Singleton, AB, Guerreiro, R, Muhleisen, TW, Nothen, MM, Moebus, S, Jockel, KH, Klopp, N, Wichmann, HE, Pankratz, VS, Sando, SB, Aasly, JO, Barcikowska, M, Wszolek, ZK, Dickson, DW, Graff-Radford, NR, Petersen, RC, Alzheimer's Disease Neuroimaging, I, van Duijn, CM, Breteler, MM, Ikram, MA, DeStefano, AL, Fitzpatrick, AL, Lopez, O, Launer, LJ, Seshadri, S, consortium, C, Berr, C, Campion, D, Epelbaum, J, Dartigues, JF, Tzourio, C, Alperovitch, A, Lathrop, M, Consortium, E, Feulner, TM, Friedrich, P, Riehle, C, Krawczak, M, Schreiber, S, Mayhaus, M, Nicolhaus, S, Wagenpfeil, S, Steinberg, S, Stefansson, H, Stefansson, K, Snaedal, J, Bjornsson, S, Jonsson, PV, Chouraki, V, Genier-Boley, B, Hiltunen, M, Soininen, H, Combarros, O, Zelenika, D,
Delepine, M, Bullido, MJ, Pasquier, F, Mateo, I, Frank-Garcia, A, Porcellini, E, Hanon, O, Coto, E, Alvarez, V, Bosco, P, Siciliano, G, Mancuso, M, Panza, F, Solfrizzi, V, Nacmias, B, Sorbi, S, Bossu, P, Piccardi, P, Arosio, B, Annoni, G, Seripa, D, Pilotto, A, Scarpini, E, Galimberti, D, Brice, A, Hannequin, D, Licastro, F, Jones, L, Holmans, PA, Jonsson, T, Riemenschneider, M, Morgan, K, Younkin, SG, Owen, MJ, O'Donovan, M, Amouyel, P and Williams, J (2011) Common variants at ABCA7, MS4A6A/MS4A4E, EPHA1 CD33 and CD2AP are associated with Alzheimer's disease. Nat. Genet. 43:429-435. doi: http://dx.doi.org/10.1038/ng.803. (PMID: 21460840)

Hossini, AM, Megges, M, Prigione, A, Lichtner, B, Toliat, MR, Wruck, W, Schroter, F, Nuernberg, P, Kroll, H, Makrantonaki, E, Zoubouliss, CC and Adjaye, J (2015) Induced pluripotent stem cell-derived neuronal cells from a sporadic Alzheimer's disease donor as a model for investigating AD-associated gene regulatory networks. BMC Genomics 16:84. doi: http://dx.doi.org/10.1186/s12864-015-1262-5. (PMID: 25765079)

Hotta, Y., 2008. Ethical issues of the research on human embryonic stem cells. J. Int Bioethique 19 (77-85), 124-125 (PMID: 19244943).

Hsu, P.D., Lander, E.S., Zhang, F., 2014. Development and applications of CRISPR-Cas9 for genome engineering. Cell 157, 1262-1278. http://dx.doi.org/10.1016/j.cell.2014.05. 010 (PMID: 24906146).

Hsu, P.D., Scott, D.A., Weinstein, J.A., Ran, F.A., Konermann, S., Agarwala, V., Li, Y., Fine, E.J., Wu, X., Shalem, O., Cradick, T.J., Marraffini, L.A., Bao, G., Zhang, F., 2013. DNA targeting specificity of RNA-guided Cas9 nucleases. Nat. Biotechnol. 31, 827-832. http://dx.doi. org/10.1038/nbt.2647 (PMID: 23873081).

Hu, B.Y., Du, Z.W., Zhang, S.C., 2009. Differentiation of human oligodendrocytes from pluripotent stem cells. Nat. Protoc. 4, 1614-1622. http://dx.doi.org/10.1038/nprot 2009.186 (PMID: 19834476).

Hu, B.-Y., Weick, J.P., Yu, J., Ma, L.-X., Zhang, X.-Q., Thomson, J.A., Zhang, S.-C., 2010. Neura differentiation of human induced pluripotent stem cells follows developmental principles but with variable potency. Proc. Natl. Acad. Sci. 107, 4335-4340. http:// dx.doi.org/10.1073/pnas.0910012107.

Hutton, M., Lendon, C.L., Rizzu, P., Baker, M., Froelich, S., Houlden, H.H., Pickering-Brown S., Chakraverty, S., Isaacs, A., Grover, A., Hackett, J., Adamson, J., Lincoln, S., Dickson, D., Davies, P., Petersen, R.C., Stevena, M., De Graaff, E., Wauters, E., Van Baren, J., Hillebrand, M., Joosse, M., Kwon, J.M., Nowotny, P., Che, L.K., Norton, J., Morris, J.C., Reed, L.A., Trojanowski, J., Basun, H., Lannfelt, L., Neystat, M., Fahn, S., Dark, F. Tannenberg, T., Dodd, P.R., Hayward, N., Kwok, J.B.J., Schofield, P.R., Andreadis, A., Snowden, J., Craufurd, D., Neary, D., Owen, F., Costra, B.A., Hardy, J., Goate, A., Van Swieten, J., Mann, D., Lynch, T., Heutink, P., 1998. Association of missense and 5'splice-site mutations in tau with the inherited dementia FTDP-17. Nature 393, 702-704 (PMID: 9641683).

Iovino, M., Agathou, S., Gonzalez-Rueda, A., Del Castillo Velasco-Herrera, M., Borroni, B. Alberici, A., Lynch, T., O'Dowd, S., Geti, I., Gaffney, D., Vallier, L., Paulsen, O., Karadottir R.T., Spillantini, M.G., 2015. Early maturation and distinct tau pathology in induced pluripotent stem cell-derived neurons from patients with MAPT mutations. Brain http://dx.doi.org/10.1093/brain/awv222 (PMID: 26220942)

Isobe, K., Cheng, Z., Nishio, N., Suganya, T., Tanaka, Y., Ito, S., 2014. IPSCs, aging and agerelated diseases. New Biotechnol. 31, 411-421. http://dx.doi.org/10.1016/j.nbt.2014. 04.004 (PMID: 24784583).

Israel, M.A., Yuan, S.H., Bardy, C., Reyna, S.M., Mu, Y., Herrera, C., Hefferan, M.P., Van Gorp, S., Nazor, K.L., Boscolo, F.S., Carson, C.T., Laurent, L.C., Marsala, M., Gage, F.H., Remes, A.M., Koo, E.H., Goldstein, L.S., 2012. Probing sporadic and familial Alzheimer's disease using induced pluripotent stem cells. Nature 482, 216-220. http://dx.doi. org/10.1038/nature10821 (PMID: 22278060)

Jang, J., Kang, H.C., Kim, H.S., Kim, J.Y., Huh, Y.J., Kim, D.S., Yoo, J.E., Lee, J.A., Lim, B., Lee, J. Yoon, T.M., Park, I.H., Hwang, D.Y., Daley, G.Q., Kim, D.W., 2011. Induced pluripotent stem cell models from X-linked adrenoleukodystrophy patients. Ann. Neurol. 70, 402-409. http://dx.doi.org/10.1002/ana.22486 (PMID: 21721033).

Jarrett, J.T., Berger, E.P., Lansbury Jr., P.T., 1993. The carboxy terminus of the beta amyloid protein is critical for the seeding of amyloid formation: implications for the pathogenesis of Alzheimer's disease. Biochemistry 32, 4693-4697 (PMID: 8490014).

Jessen, N.A., Munk, A.S., Lundgaard, I., Nedergaard, M., 2015. The glymphatic system: a beginner's guide. Neurochem. Res. http://dx.doi.org/10.1007/s11064-015-1581-6 (PMID: 25947369)

Jinek, M., Chylinski, K., Fonfara, I., Hauer, M., Doudna, J.A., Charpentier, E., 2012. A programmable dual-RNA-guided DNA endonuclease in adaptive bacterial immunity. Science 337, 816-821.

Jonsson, T., Stefansson, H., Steinberg, S., Jonsdottir, I., Jonsson, P.V., Snaedal, J., Bjornsson, S., Huttenlocher, J., Levey, A.I., Lah, J.J., Rujescu, D., Hampel, H., Giegling I, Andreassen, O.A., Engedal, K., Ulstein, I., Djurovic, S., Ibrahim-Verbaas, C., Hofman, A., Ikram, M.A., van Duijn, C.M., Thorsteinsdottir, U., Kong, A., Stefansson, K., 2013. Variant of TREM2 associated with the risk of Alzheimer's disease. N. Engl. J. Med. 368, 107-116. http://dx.doi.org/10.1056/NEJMoa1211103 (PMID: 23150908).

Joung, J.K., Sander, J.D., 2013. TALENs: a widely applicable technology for targeted genome editing. Nat. Rev. Mol. Cell Biol. 14, 49-55. http://dx.doi.org/10.1038/nrm3486 (PMID: 23169466)

Kadoshima, T., Sakaguchi, H., Nakano, T., Soen, M., Ando, S., Eiraku, M., Sasai, Y., 2013. Selforganization of axial polarity, inside-out layer pattern, and species-specific progenitor dynamics in human ES cell-derived neocortex. Proc. Natl. Acad. Sci. U. S. A. 110 http://dx.doi.org/10.1073/pnas.1315710110 (20284-119, PMID: 24277810).

Kamm, F.M., 2005. Ethical issues in using and not using embryonic stem cells. Stem Cell Rev. 1, 325-330. http://dx.doi.org/10.1385/SCR:1:4:325 (PMID: 17142875).

Kanekiyo, T., Xu, H., Bu, G., 2014. ApoE and Abeta in Alzheimer's disease: accidental encounters or partners? Neuron 81, 740-754. http://dx.doi.org/10.1016/j.neuron. 2014.01.045 (PMID: 24559670).

Kang, J., Lemaire, H.G., Unterbeck, A., Salbaum, J.M., Masters, C.L., Grzeschik, K.H. Multhaup, G., Beyreuther, K., Muller-Hill, B., 1987. The precursor of Alzheimer's 
disease amyloid A4 protein resembles a cell-surface receptor. Nature 325, 733-736. http://dx.doi.org/10.1038/325733a0 (PMID: 2881207).

Khakh, B.S., McCarthy, K.D., 2015. Astrocyte calcium signaling: from observations to functions and the challenges therein. Cold Spring Harb. Perspect. Biol. 7, a020404. http://dx.doi.org/10.1101/cshperspect.a020404 (PMID: 25605709).

Khurana, V., Tardiff, D.F., Chung, C.Y., Lindquist, S., 2015. Toward stem cell-based phenotypic screens for neurodegenerative diseases. Nat. Rev. Neurol. 11, 339-350. http://dx.doi.org/10.1038/nrneurol.2015.79 (PMID: 25986505).

Kim, D., Frank, C.L., Dobbin, M.M., Tsunemoto, R.K., Tu, W., Peng, P.L., Guan, J.S., Lee, B.H., Moy, L.Y., Giusti, P., Broodie, N., Mazitschek, R., Delalle, I., Haggarty, S.J., Neve, R.L., Lu, Y., Tsai, L.H., 2008. Deregulation of HDAC1 by p25/Cdk5 in neurotoxicity. Neuron 60, 803-817 (PMID: 19081376).

Kim, D.S., Lee, D.R., Kim, H.S., Yoo, J.E., Jung, S.J., Lim, B.Y., Jang, J., Kang, H.C., You, S. Hwang, D.Y., Leem, J.W., Nam, T.S., Cho, S.R., Kim, D.W., 2012. Highly pure and expandable PSA-NCAM-positive neural precursors from human ESC and iPSCderived neural rosettes. PLoS One 7, e39715. http://dx.doi.org/10.1371/journal. pone.0039715 (PMID: 22911689)

Kim, H., Lee, G., Ganat, Y., Papapetrou, E.P., Lipchina, I., Socci, N.D., Sadelain, M., Studer, L, 2011. miR-371-3 expression predicts neural differentiation propensity in human pluripotent stem cells. Cell Stem Cell 8, 695-706. http://dx.doi.org/10.1016/j.stem. 2011.04.002 (PMID: 21624813).

Kim, J., Basak, J.M., Holtzman, D.M., 2009. The role of apolipoprotein E in Alzheimer's disease. Neuron 63, 287-303 (PMID: 19679070).

Kim, K., Doi, A., Wen, B., Ng, K., Zhao, R., Cahan, P., Kim, J., Aryee, M.J., Ji, H., Ehrlich, L.I.R. Yabuuchi, A., Takeuchi, A., Cunniff, K.C., Hongguang, H., McKinney-Freeman, S. Naveiras, O., Yoon, T.J., Irizarry, R.A., Jung, N., Seita, J., Hanna, J., Murakami, P. Jaenisch, R., Weissleder, R., Orkin, S.H., Weissman, I.L., Feinberg, A.P., Daley, G.Q. 2010. Epigenetic memory in induced pluripotent stem cells. Nature 467. http://dx. doi.org/10.1038/nature09342 (285-U60, PMID: 20644535).

Kim, Y.H., Choi, S.H., D'Avanzo, C., Hebisch, M., Sliwinski, C., Bylykbashi, E., Washicosky, K.J., Klee, J.B., Brustle, O., Tanzi, R.E., Kim, D.Y., 2015. A 3D human neural cell culture system for modeling Alzheimer's disease. Nat. Protoc. 10, 985-1006. http://dx.doi. org/10.1038/nprot.2015.065 (PMID: 26068894).

King, N.M., Perrin, J., 2014. Ethical issues in stem cell research and therapy. Stem Cell Res. Ther. 5, 85. http://dx.doi.org/10.1186/scrt474 (PMID: 25157428).

Kobayashi, K., Hayashi, M., Nakano, H., Fukutani, Y., Sasaki, K., Shimazaki, M., Koshino, Y. 2002. Apoptosis of astrocytes with enhanced lysosomal activity and oligodendrocytes in white matter lesions in Alzheimer's disease. Neuropathol. Appl. Neurobiol. 28 238-251 (PMID: 12060348)

Koch, P., Tamboli, I.Y., Mertens, J., Wunderlich, P., Ladewig, J., Stuber, K., Esselmann, H., Wiltfang, J., Brustle, O., Walter, J., 2012. Presenilin-1 L166P mutant human pluripotent stem cell-derived neurons exhibit partial loss of gamma-secretase activity in endogenous amyloid-beta generation. Am. J. Pathol. 180, 2404-2416. http://dx.doi. org/10.1016/j.ajpath.2012.02.012 (PMID: 22510327)

Koche, R.P., Smith, Z.D., Adli, M., Gu, H.C., Ku, M.C., Gnirke, A., Bernstein, B.E., Meissner, A. 2011. Reprogramming factor expression initiates widespread targeted chromatin remodeling. Cell Stem Cell 8, 96-105. http://dx.doi.org/10.1016/j.stem.2010.12.001 (PMID: 21211784).

Kondo, T., Asai, M., Tsukita, K., Kutoku, Y., Ohsawa, Y., Sunada, Y., Imamura, K., Egawa, N., Yahata, N., Okita, K., Takahashi, K., Asaka, I., Aoi, T., Watanabe, A., Watanabe, K., Kadoya, C., Nakano, R., Watanabe, D., Maruyama, K., Hori, O., Hibino, S., Choshi, T. Nakahata, T., Hioki, H., Kaneko, T., Naitoh, M., Yoshikawa, K., Yamawaki, S., Suzuki, S., Hata, R., Ueno, S., Seki, T., Kobayashi, K., Toda, T., Murakami, K., Irie, K., Klein, W.L., Mori, H., Asada, T., Takahashi, R., Iwata, N., Yamanaka, S., Inoue, H., 2013. Modeling Alzheimer's disease with iPSCs reveals stress phenotypes associated with intracellular Abeta and differential drug responsiveness. Cell Stem Cell 12, 487-(496). http://dx.doi.org/10.1016/j.stem.2013.01.009 (PMID: 23434393).

Kosik, K.S., Joachim, C.L., Selkoe, D.J., 1986. Microtubule-associated protein tau (tau) is a major antigenic component of paired helical filaments in Alzheimer disease. Proc. Natl. Acad. Sci. U. S. A. 83, 4044-4048 (PMID: 2424016).

Kraepelin, E., 1910. Psychiatrie. Barth, Leipzig.

Krantic, S., Isorce, N., Mechawar, N., Davoli, M.A., Vignault, E., Albuquerque, M., Chabot, J.G. Moyse, E., Chauvin, J.P., Aubert, I., McLaurin, J., Quirion, R., 2012. Hippocampa GABAergic neurons are susceptible to amyloid-beta toxicity in vitro and are decreased in number in the Alzheimer's disease TgCRND8 mouse model. J. Alzheimers Dis. 29, 293-308. http://dx.doi.org/10.3233/JAD-2011-110830 (PMID: 22232004).

Krencik, R., Zhang, S.C., 2011. Directed differentiation of functional astroglial subtypes from human pluripotent stem cells. Nat. Protoc. 6, 1710-1717. http://dx.doi.org/10. 1038/nprot.2011.405 (PMID: 22011653).

Krencik, R., Weick, J.P., Liu, Y., Zhang, Z.J., Zhang, S.C., 2011. Specification of transplantable astroglial subtypes from human pluripotent stem cells. Nat. Biotechnol. 29, 528-534. http://dx.doi.org/10.1038/nbt.1877 (PMID: 21602806).

Lai, S., Zhang, M., Xu, D., Zhang, Y., Qiu, L., Tian, C., Zheng, J.C., 2015. Direct reprogramming of induced neural progenitors: a new promising strategy for AD treatment. Transl. Neurodegener. 4, 7. http://dx.doi.org/10.1186/s40035-015-0028-y (PMID: 25949812)

Lambert, J.C., Grenier-Boley, B., Chouraki, V., Heath, S., Zelenika, D., Fievet, N., Hannequin, D., Pasquier, F., Hanon, O., Brice, A., Epelbaum, J., Berr, C., Dartigues, J.F., Tzourio, C. Campion, D., Lathrop, M., Amouyel, P., 2010. Implication of the immune system in Alzheimer's disease: evidence from genome-wide pathway analysis. J. Alzheimers Dis. 20, 1107-1118. http://dx.doi.org/10.3233/JAD-2010-100018 (PMID: 20413860).

Lambert, J.C., Heath, S., Even, G., Campion, D., Sleegers, K., Hiltunen, M., Combarros, O., Zelenika, D., Bullido, M.J., Tavernier, B., Letenneur, L., Bettens, K., Berr, C., Pasquier, F., Fievet, N., Barberger-Gateau, P., Engelborghs, S., De Deyn, P., Mateo, I., Franck, A Helisalmi, S., Porcellini, E., Hanon, O., European Alzheimer's Disease Initiative, I., de
Pancorbo, M.M., Lendon, C., Dufouil, C., Jaillard, C., Leveillard, T., Alvarez, V., Bosco, P., Mancuso, M., Panza, F., Nacmias, B., Bossu, P., Piccardi, P., Annoni, G., Seripa, D., Galimberti, D., Hannequin, D., Licastro, F., Soininen, H., Ritchie, K., Blanche, H., Dartigues, J.F., Tzourio, C., Gut, I., Van Broeckhoven, C., Alperovitch, A., Lathrop, M., Amouyel, P. 2009. Genome-wide association study identifies variants at CLU and CR1 associated with Alzheimer's disease. Nat. Genet. 41, 1094-1099. http://dx.doi. org/10.1038/ng.439 (PMID: 19734903).

Lambert, J.C., Ibrahim-Verbaas, C.A., Harold, D., Naj, A.C., Sims, R., Bellenguez, C., Jun, G., Destefano, A.L., Bis, J.C., Beecham, G.W., Grenier-Boley, B., Russo, G., ThorntonWells, T.A., Jones, N., Smith, A.V., Chouraki, V., Thomas, C., Ikram, M.A., Zelenika, D., Vardarajan, B.N., Kamatani, Y., Lin, C.F., Gerrish, A., Schmidt, H., Kunkle, B., Dunstan, M.L., Ruiz, A., Bihoreau, M.T., Choi, S.H., Reitz, C., Pasquier, F., Hollingworth, P., Ramirez, A., Hanon, O., Fitzpatrick, A.L., Buxbaum, J.D., Campion, D., Crane, P.K., Baldwin, C., Becker, T., Gudnason, V., Cruchaga, C., Craig, D., Amin, N., Berr, C., Lopez, O.L., De Jager, P.L., Deramecourt, V., Johnston, J.A., Evans, D., Lovestone, S., Letenneur, L., Moron, F.J., Rubinsztein, D.C., Eiriksdottir, G., Sleegers, K., Goate, A.M., Fievet, N., Huentelman, M.J., Gill, M., Brown, K., Kamboh, M.I., Keller, L., BarbergerGateau, P., McGuinness, B., Larson, E.B., Green, R., Myers, A.J., Dufouil, C., Todd, S., Wallon, D., Love, S., Rogaeva, E., Gallacher, J., St George-Hyslop, P., Clarimon, J., Lleo, A., Bayer, A., Tsuang, D.W., Yu, L., Tsolaki, M., Bossu, P., Spalletta, G., Proitsi, P., Collinge, J., Sorbi, S., Sanchez-Garcia, F., Fox, N.C., Hardy, J., Naranjo, M.C., Bosco, P., Clarke, R., Brayne, C., Galimberti, D., Mancuso, M., Matthews, F., European Alzheimer's Disease, I, Genetic, Environmental Risk in Alzheimer's, D, Alzheimer's Disease Genetic, C, Cohorts for, H, Aging Research in Genomic, E, Moebus, S., Mecocci, P., Del Zompo, M., Maier, W., Hampel, H., Pilotto, A., Bullido, M., Panza, F., Caffarra, P., Nacmias, B., Gilbert, J.R., Mayhaus, M., Lannfelt, L., Hakonarson, H., Pichler, S., Carrasquillo, M.M. Ingelsson, M., Beekly, D., Alvarez, V., Zou, F., Valladares, O., Younkin, S.G., Coto, E., Hamilton-Nelson, K.L., Gu, W., Razquin, C., Pastor, P., Mateo, I., Owen, M.J., Faber, K.M., Jonsson, P.V., Combarros, O., O'Donovan, M.C., Cantwell, L.B., Soininen, H., Blacker, D., Mead, S., Mosley Jr., T.H., Bennett, D.A., Harris, T.B., Fratiglioni, L., Holmes, C., de Bruijn, R.F., Passmore, P., Montine, T.J., Bettens, K., Rotter, J.I., Brice, A., Morgan, K., Foroud, T.M., Kukull, W.A., Hannequin, D., Powell, J.F., Nalls, M.A., Ritchie, K., Lunetta, K.L., Kauwe, J.S., Boerwinkle, E., Riemenschneider, M., Boada, M., Hiltunen, M., Martin, E.R., Schmidt, R., Rujescu, D., Wang, L.S., Dartigues, J.F., Mayeux, R., Tzourio, C., Hofman, A., Nothen, M.M., Graff, C., Psaty, B.M., Jones, L., Haines, J.L., Holmans, P.A., Lathrop, M., Pericak-Vance, M.A., Launer, L.J., Farrer, L.A., van Duijn, C.M., Van Broeckhoven, C., Moskvina, V., Seshadri, S., Williams, J., Schellenberg, G.D., Amouyel, P., 2013. Meta-analysis of 74,046 individuals identifies 11 new susceptibility loci for Alzheimer's disease. Nat. Genet. http://dx.doi.org/10.1038/ng.2802 (PMID: 24162737)

Lancaster, M.A., Knoblich, J.A., 2014. Generation of cerebral organoids from human pluripotent stem cells. Nat. Protoc. 9, 2329-2340. http://dx.doi.org/10.1038/nprot.2014.158 (PMID: 25188634).

Lancaster, M.A., Renner, M., Martin, C.-A., Wenzel, D., Bicknell, L.S., Hurles, M.E., Homfray, T., Penninger, J.M., Jackson, A.P., Knoblich, J.A., 2013. Cerebral organoids model human brain development and microcephaly. Nature 501, 373-+. http://dx.doi.org/ 10.1038/nature12517 (PMID: 23995685).

Lassmann, H., Bancher, C., Breitschopf, H., Wegiel, J., Bobinski, M., Jellinger, K., Wisniewski, H.M., 1995. Cell-death in alzheimers-disease evaluated by DNA fragmentation in-situ, Acta Neuropathol. 89, 35-41 (PMID: 7709729).

Lee, G., Papapetrou, E.P., Kim, H., Chambers, S.M., Tomishima, M.J., Fasano, C.A., Ganat, Y.M., Menon, J., Shimizu, F., Viale, A., Tabar, V., Sadelain, M., Studer, L., 2009. Modelling pathogenesis and treatment of familial dysautonomia using patient-specific iPSCs. Nature 461, 402-406 (PMID: 19693009).

Lee, M.S., Kao, S.C., Lemere, C.A., Xia, W., Tseng, H.C., Zhou, Y., Neve, R., Ahlijanian, M.K., Tsai, L.H., 2003. APP processing is regulated by cytoplasmic phosphorylation. J. Cell Biol. 163, 83-95. http://dx.doi.org/10.1083/jcb.200301115 (jcb.200301115[pii]. PMID: 14557249)

Lemere, C.A., Blusztajn, J.K., Yamaguchi, H., Wisniewski, T., Saido, T.C., Selkoe, D.J., 1996. Sequence of deposition of heterogeneous amyloid beta-peptides and APO E in Down syndrome: implications for initial events in amyloid plaque formation. Neurobiol. Dis. 3, 16-32. http://dx.doi.org/10.1006/nbdi.1996.0003 (PMID: 9173910).

Levy-Lahad, E., Wasco, W., Poorkaj, P., Romano, D.M., Oshima, J., Pettingell, W.H., Yu, C.E., Jondro, P.D., Schmidt, S.D., Wang, K., et al., 1995a. Candidate gene for the chromosome 1 familial Alzheimer's disease locus. Science 269, 973-977 (PMID: 7638622).

Levy-Lahad, E., Wijsman, E.M., Nemens, E., Anderson, L., Goddard, K.A., Weber, J.L., Bird, T.D., Schellenberg, G.D., 1995b. A familial Alzheimer's disease locus on chromosome 1. Science 269, 970-973 (PMID: 7638621).

Li, S., Mallory, M., Alford, M., Tanaka, S., Masliah, E., 1997. Glutamate transporter alterations in Alzheimer disease are possibly associated with abnormal APP expression. J. Neuropathol. Exp. Neurol. 56, 901-911 (PMID: 9258260).

Lippmann, E.S., Al-Ahmad, A., Azarin, S.M., Palecek, S.P., Shusta, E.V., 2014. A retinoic acid-enhanced, multicellular human blood-brain barrier model derived from stem cell sources. Sci. Rep. 4, 4160. http://dx.doi.org/10.1038/srep04160 (PMID: 24561821)

Lippmann, E.S., Al-Ahmad, A., Palecek, S.P., Shusta, E.V., 2013. Modeling the blood-brain barrier using stem cell sources. Fluids Barriers CNS 10, 2. http://dx.doi.org/10.1186/ 2045-8118-10-2 (PMID: 23305164).

Lippmann, E.S., Azarin, S.M., Kay, J.E., Nessler, R.A., Wilson, H.K., Al-Ahmad, A., Palecek, S.P., Shusta, E.V., 2012. Derivation of blood-brain barrier endothelial cells from human pluripotent stem cells. Nat. Biotechnol. 30, 783-791. http://dx.doi.org/10. 1038/nbt.2247 (PMID: 22729031)

Lister, R., Pelizzola, M., Kida, Y.S., Hawkins, R.D., Nery, J.R., Hon, G., Antosiewicz-Bourget, J., O'Malley, R., Castanon, R., Klugman, S., Downes, M., Yu, R., Stewart, R., Ren, B. Thomson, J.A., Evans, R.M., Ecker, J.R., 2011. Hotspots of aberrant epigenomic 
reprogramming in human induced pluripotent stem cells. Nature 471. http://dx.doi. org/10.1038/nature09798 (68-U84, PMID: 21289626).

Liu, C.C., Kanekiyo, T., Xu, H., Bu, G., 2013. Apolipoprotein E and Alzheimer disease: risk, mechanisms and therapy. Nat. Rev. Neurol. (PMID: 23296339).

Liu, G.H., Barkho, B.Z., Ruiz, S., Diep, D., Qu, J., Yang, S.L., Panopoulos, A.D., Suzuki, K. Kurian, L., Walsh, C., Thompson, J., Boue, S., Fung, H.L., Sancho-Martinez, I., Zhang, K., Yates 3rd, J., Izpisua Belmonte, J.C., 2011. Recapitulation of premature ageing with iPSCs from Hutchinson-Gilford progeria syndrome. Nature 472, 221-225. http://dx.doi.org/10.1038/nature09879 (PMID: 21346760).

Liu, G.H., Qu, J., Suzuki, K., Nivet, E., Li, M., Montserrat, N., Yi, F., Xu, X., Ruiz, S., Zhang, W., Wagner, U., Kim, A., Ren, B., Li, Y., Goebl, A., Kim, J., Soligalla, R.D., Dubova, I., Thompson, J., Yates 3rd, J., Esteban, C.R., Sancho-Martinez, I., Izpisua Belmonte, J.C. 2012. Progressive degeneration of human neural stem cells caused by pathogenic LRRK2. Nature 491, 603-607. http://dx.doi.org/10.1038/nature11557 (PMID: 23075850).

Liu, H., Zhang, S.C., 2011. Specification of neuronal and glial subtypes from human pluripotent stem cells. Cell. Mol. Life Sci. 68, 3995-4008. http://dx.doi.org/10.1007/ s00018-011-0770-y (PMID: 21786144).

Liu, Y., Liu, H., Sauvey, C., Yao, L., Zarnowska, E.D., Zhang, S.C., 2013. Directed differentiation of forebrain GABA interneurons from human pluripotent stem cells. Nat. Protoc. 8, 1670-1679. http://dx.doi.org/10.1038/nprot.2013.106 (PMID: 23928500).

Lomax, G.P., Peckman, S.R., 2012. Stem cell policy exceptionalism: proceed with caution. Stem Cell Rev. 8, 299-304. http://dx.doi.org/10.1007/s12015-011-9305-z (PMID: 21837381).

Lomax, G.P., Hull, S.C., Isasi, R., 2015. The DISCUSS project: revised points to consider for the derivation of induced pluripotent stem cell lines from previously collected research specimens. Stem Cells Transl. Med. 4, 123-129. http://dx.doi.org/10.5966/ sctm.2014-0192 (PMID: 25561681).

Lomax, G.P., Hull, S.C., Lowenthal, J., Rao, M., Isasi, R., 2013. The DISCUSS project: induced pluripotent stem cell lines from previously collected research biospecimens and informed consent: points to consider. Stem Cells Transl. Med. 2, 727-730. http://dx. doi.org/10.5966/sctm.2013-0099 (PMID: 23990574).

Lovell, M.A., Markesbery, W.R., 2007. Oxidative DNA damage in mild cognitive impairment and late-stage Alzheimer's disease. Nucleic Acids Res. 35, 7497-7504.

Lu, T., Pan, Y., Kao, S.Y., Li, C., Kohane, I., Chan, J., Yankner, B.A., 2004. Gene regulation and DNA damage in the ageing human brain. Nature 429, 883-891.

Lue, L.F., Walker, D.G., Rogers, J., 2001. Modeling microglial activation in Alzheimer's disease with human postmortem microglial cultures. Neurobiol. Aging 22, 945-956. http://dx.doi.org/10.1016/s0197-4580(01)00311-6 (PMID: 11755003).

Ma, N., Shan, Y., Liao, B., Kong, G., Wang, C., Huang, K., Zhang, H., Cai, X., Chen, S., Pei, D., Chen, N., Pan, G., 2015. Factor-induced reprogramming and zinc finger nucleaseaided gene targeting cause different genome instability in beta-thalassemia induced pluripotent stem cells (iPSCs). J. Biol. Chem. 290, 12079-12089. http://dx.doi.org/ 10.1074/jbc.M114.624999 (PMID: 25795783).

Ma, Y.J., Hill, D.F., Creswick, K.E., Costa, M.E., Cornea, A., Lioubin, M.N., Plowman, G.D., Ojeda, S.R., 1999. Neuregulins signaling via a glial erbB-2-erbB-4 receptor complex contribute to the neuroendocrine control of mammalian sexual development. J. Neurosci. 19, 9913-9927 (PMID: 10559400).

Maclean, G.A., Menne, T.F., Guo, G., Sanchez, D.J., Park, I.H., Daley, G.Q., Orkin, S.H., 2012. Altered hematopoiesis in trisomy 21 as revealed through in vitro differentiation of isogenic human pluripotent cells. Proc. Natl. Acad. Sci. U. S. A. 109, 17567-17572. http://dx.doi.org/10.1073/pnas.1215468109 (PMID: 23045682).

Mahley, R.W., 1988. Apolipoprotein E: cholesterol transport protein with expanding role in cell biology. Science 240 (PMID: 3283935).

Mahley, R.W., Rall Jr., S.C., 2000. Apolipoprotein E: far more than a lipid transport protein. Annu. Rev. Genomics Hum. Genet. (PMID: 11701639).

Mahmoudi, S., Brunet, A., 2012. Aging and reprogramming: a two-way street. Curr. Opin. Cell Biol. 24, 744-756. http://dx.doi.org/10.1016/j.ceb.2012.10.004 (PMID: 23146768).

Majewski, J., Pastinen, T., 2011. The study of eQTL variations by RNA-seq: from SNPs to phenotypes. Trends Genet. 27, 72-79. http://dx.doi.org/10.1016/j.tig.2010.10.006 (PMID: 21122937)

Major, T., Menon, J., Auyeung, G., Soldner, F., Hockemeyer, D., Jaenisch, R., Tabar, V., 2011. Transgene excision has no impact on in vivo integration of human iPS derived neural precursors. PLoS One 6, e24687. http://dx.doi.org/10.1371/journal.pone.0024687 (PMID: 21961042).

Mali, P., Yang, L., Esvelt, K.M., Aach, J., Guell, M., DiCarlo, J.E., Norville, J.E., Church, G.M., 2013. RNA-guided human genome engineering via Cas9. Science (New York, N.Y.) http://dx.doi.org/10.1126/science.1232033.

Mann, E.O., Paulsen, O., 2007. Role of GABAergic inhibition in hippocampal network oscillations. Trends Neurosci. 30, 343-349. http://dx.doi.org/10.1016/j.tins.2007.05. 003 (PMID: 17532059).

Marchetto, M.C.N., Carromeu, C., Acab, A., Yu, D., Yeo, G.W., Mu, Y., Chen, G., Gage, F.H., Muotri, A.R., 2010. A model for neural development and treatment of rett syndrome using human induced pluripotent stem cells. Cell 143, 527-539. http://dx.doi.org/10. 1016/j.cell.2010.10.016 (PMID: 21074045).

Martin, G.R., 1981. Isolation of a pluripotent cell line from early mouse embryos cultured in medium conditioned by teratocarcinoma stem cells. Proc. Natl. Acad. Sci. U. S. A. 78, 7634-7638. http://dx.doi.org/10.1073/pnas.78.12.7634 (PMID: 6950406).

Masliah, E., Alford, M., Mallory, M., Rockenstein, E., Moechars, D., Van Leuven, F., 2000. Abnormal glutamate transport function in mutant amyloid precursor protein transgenic mice. Exp. Neurol. 163, 381-387.

Masumoto, H., Ikuno, T., Takeda, M., Fukushima, H., Marui, A., Katayama, S., Shimizu, T., Ikeda, T., Okano, T., Sakata, R., Yamashita, J.K., 2014. Human iPS cell-engineered cardiac tissue sheets with cardiomyocytes and vascular cells for cardiac regeneration. Sci. Rep. 4, 6716. http://dx.doi.org/10.1038/srep06716 (PMID: 25336194).

Mattis, V.B., Tom, C., Akimov, S., Saeedian, J., Ostergaard, M.E., Southwell, A.L., Doty, C.N., Ornelas, L., Sahabian, A., Lenaeus, L., Mandefro, B., Sareen, D., Arjomand, J., Hayden,
M.R., Ross, C.A., Svendsen, C.N., 2015. HD iPSC-derived neural progenitors accumulate in culture and are susceptible to BDNF withdrawal due to glutamate toxicity. Hum. Mol. Genet. 24, 3257-3271. http://dx.doi.org/10.1093/hmg/ddv080 (PMID: 25740845).

McBride, R., 2012. Pharma Counts Just 3 Alzheimer's Drug Wins in 13 years (101 Losses!). FierceBiotech.

Mertens, J., Stuber, K., Wunderlich, P., Ladewig, J., Kesavan, J.C., Vandenberghe, R., Vandenbulcke, M., van Damme, P., Walter, J., Brustle, O., Koch, P., 2013. APP processing in human pluripotent stem cell-derived neurons is resistant to NSAIDbased gamma-secretase modulation. Stem Cell Rep. 1, 491-498. http://dx.doi.org/ 10.1016/j.stemcr.2013.10.011 (PMID: 24371804).

Miller, J., Studer, L., 2014. Aging in iPS cells. Aging (Albany NY) 6, 246-247 (PMID: 24799443).

Miller, J.C., Tan, S., Qiao, G., Barlow, K.A., Wang, J., Xia, D.F., Meng, X., Paschon, D.E., Leung, E., Hinkley, S.J., Dulay, G.P., Hua, K.L., Ankoudinova, I., Cost, G.J., Urnov, F.D., Zhang, H.S., Holmes, M.C., Zhang, L., Gregory, P.D., Rebar, E.J., 2011. A TALE nuclease architecture for efficient genome editing. Nat. Biotechnol. 29, 143-148. http://dx.doi.org/10 1038/nbt.1755 (PMID: 21179091).

Miller, J.D., Ganat, Y.M., Kishinevsky, S., Bowman, R.L., Liu, B., Tu, E.Y., Mandal, P.K., Vera, E. Shim, J.W., Kriks, S., Taldone, T., Fusaki, N., Tomishima, M.J., Krainc, D., Milner, T.A. Rossi, D.J., Studer, L., 2013. Human iPSC-based modeling of late-onset disease via progerin-induced aging. Cell Stem Cell 13, 691-705. http://dx.doi.org/10.1016/j. stem.2013.11.006 (PMID: 24315443),

Minami, H., Tashiro, K., Okada, A., Hirata, N., Yamaguchi, T., Takayama, K., Mizuguchi, H. Kawabata, K., 2015. Generation of brain microvascular endothelial-like cells from human induced pluripotent stem cells by co-culture with C6 glioma cells. PLoS One 10, e0128890. http://dx.doi.org/10.1371/journal.pone.0128890 (PMID: 26061227).

Monoranu, C.M., Apfelbacher, M., Gruenblatt, E., Puppe, B., Alafuzoff, I., Ferrer, I., Al-Saraj, S., Keyvani, K.. Schmitt, A., Falkai, P., Schittenhelm, J., Halliday, G., Kril, J., Harper, C., McLean, C., Riederer, P., Roggendorf, W., 2009. Abstracts of the 110th Meeting of the British Neuropathological Society. January 7-9, 2009. London, United Kingdom. Neuropathol. Appl. Neurobiol. 35 (Suppl. 1), 1-38. http://dx.doi.org/10.1111/j.13652990.2008.01003 x (PMID: 19146648).

Muratore, C.R., Rice, H.C., Srikanth, P., Callahan, D.G., Shin, T., Benjamin, L.N., Walsh, D.M. Selkoe, D.J., Young-Pearse, T.L., 2014. The familial Alzheimer's disease APPV717 mutation alters APP processing and Tau expression in iPSC-derived neurons. Hum. Mol. Genet. 23, 3523-3536. http://dx.doi.org/10.1093/hmg/ddu064 (PMID: 24524897)

Murray, A., Letourneau, A., Canzonetta, C., Stathaki, E., Gimelli, S., Sloan-Bena, F., Abrehart, R., Goh, P., Lim, S., Baldo, C., Dagna-Bricarelli, F., Hannan, S., Mortensen, M., Ballard, D. Syndercombe Court, D., Fusaki, N., Hasegawa, M., Smart, T.G., Bishop, C., Antonarakis, S.E., Groet, J., Nizetic, D., 2015. Brief report: isogenic induced pluripotent stem cell lines from an adult with mosaic down syndrome model accelerated neuronal ageing and neurodegeneration. Stem Cells 33, 2077-2084. http://dx.doi.org/10.1002/stem. 1968 (PMID: 25694335)

Narsinh, K.H., Plews, J., Wu, J.C., 2011a. Comparison of human induced pluripotent and embryonic stem cells: fraternal or identical twins? Mol. Ther. 19, 635-638. http:// dx.doi.org/10.1038/mt2011.41 (PMID: 21455209).

Narsinh, K.H., Sun, N., Sanchez-Freire, V., Lee, A.S., Almeida, P., Hu, S., Jan, T., Wilson, K.D., Leong, D., Rosenberg, J., Yao, M., Robbins, R.C., Wu, J.C., 2011b. Single cell transcriptional profiling reveals heterogeneity of human induced pluripotent stem cells. J. Clin. Invest. 121, 1217-1221. http://dx.doi.org/10.1172/JCI44635 (PMID: 21317531).

Nazor, K.L., Altun, G., Lynch, C., Tran, H., Harness, J.V., Slavin, I., Garitaonandia, I., Muller F.J., Wang, Y.C., Boscolo, F.S., Fakunle, E., Dumevska, B., Lee, S., Park, H.S., Olee, T., D'Lima, D.D., Semechkin, R., Parast, M.M., Galat, V., Laslett, A.L., Schmidt, U., Keirstead, H.S., Loring, J.F., Laurent, L.C., 2012. Recurrent variations in DNA methylation in human pluripotent stem cells and their differentiated derivatives. Cell Stem Cell 10, 620-634. http://dx.doi.org/10.1016/j.stem.2012.02.013 (PMID: 22560082).

Neumann, H., Roy, K., Brüstle, O., Peitz, M., 2013. Method for obtaining human microglial precursor cells from pluripotent stem cells (Patent number: EP2424976 B1).

Nieweg, K., Andreyeva, A., van Stegen, B., Tanriover, G., Gottmann, K., 2015. Alzheimer's disease-related amyloid-beta induces synaptotoxicity in human iPS cell-derived neurons. Cell Death Dis. 6, e1709. http://dx.doi.org/10.1038/cddis.2015.72 (PMID: 25837485).

Oberheim, N.A., Takano, T., Han, X., He, W., Lin, J.H.C., Wang, F., Xu, Q., Wyatt, J.D., Pilcher W., Ojemann, J.G., Ransom, B.R., Goldman, S.A., Nedergaard, M., 2009. Uniquely hominid features of adult human astrocytes. J. Neurosci. 29, 3276-3287. http://dx. doi.org/10.1523/ineurosci.4707-08.2009.

Oberheim, N.A., Wang, X., Goldman, S., Nedergaard, M., 2006. Astrocytic complexity distinguishes the human brain. Trends Neurosci. 29, 547-553. http://dx.doi.org/10 1016/j.tins.2006.08.004 (PMID: 16938356).

Odawara, A., Saitoh, Y., Alhebshi, A.H., Gotoh, M., Suzuki, I., 2014. Long-term electrophysiological activity and pharmacological response of a human induced pluripotent stem cell-derived neuron and astrocyte co-culture. Biochem. Biophys. Res. Commun. 443 , 1176-1181. http://dx.doi.org/10.1016/j.bbrc.2013.12.142 (PMID: 24406164).

Ogawa, S., Tokumoto, Y., Miyake, J., Nagamune, T., 2011. Induction of oligodendrocyte differentiation from adult human fibroblast-derived induced pluripotent stem cells. In Vitro Cell. Dev. Biol. Anim. 47, 464-469. http://dx.doi.org/10.1007/s11626-0119435-2 (PMID: 21695581)

Ohi, Y., Qin, H., Hong, C., Blouin, L., Polo, J.M., Guo, T., Qi, Z., Downey, S.L., Manos, P.D., Rossi, D.J., Yu, J., Hebrok, M., Hochedlinger, K., Costello, J.F., Song, J.S., RamalhoSantos, M. 2011. Incomplete DNA methylation underlies a transcriptional memory of somatic cells in human iPS cells. Nat. Cell Biol. 13, 541-549. http://dx.doi.org/10. 1038/ncb2239 (PMID: 21499256)

Okita, K., Yamakawa, T., Matsumura, Y., Sato, Y., Amano, N., Watanabe, A., Goshima, N. Yamanaka, S., 2013. An efficient nonviral method to generate integration-free 
human-induced pluripotent stem cells from cord blood and peripheral blood cells. Stem Cells 31, 458-466. http://dx.doi.org/10.1002/stem.1293 (PMID: 23193063).

Olgiati, P., Politis, A.M., Papadimitriou, G.N., De Ronchi, D., Serretti, A., 2011. Genetics of late-onset Alzheimer's disease: update from the alzgene database and analysis of shared pathways. Int. J. Alzheimers Dis. 2011, 832379. http://dx.doi.org/10.4061/ 2011/832379 (PMID: 22191060).

Parent, J.M., Anderson, S.A., 2015. Reprogramming patient-derived cells to study the epilepsies. Nat. Neurosci. 18, 360-366. http://dx.doi.org/10.1038/nn.3944 (PMID: 25710838)

Park, I.H., Arora, N., Huo, H., Maherali, N., Ahfeldt, T., Shimamura, A., Lensch, M.W., Cowan, C., Hochedlinger, K., Daley, G.Q., 2008. Disease-specific induced pluripotent stem cells. Cell 134, 877-886. http://dx.doi.org/10.1016/j.cell.2008.07.041 ([pii] S00928674(08)01001-5 PMID: 18691744).

Pasca, A.M., Sloan, S.A., Clarke, L.E., Tian, Y., Makinson, C.D., Huber, N., Kim, C.H., Park, J.Y., O'Rourke, N.A., Nguyen, K.D., Smith, S.J., Huguenard, J.R., Geschwind, D.H., Barres, B.A., Pasca, S.P., 2015. Functional cortical neurons and astrocytes from human pluripotent stem cells in 3D culture. Nat. Methods 12, 671-678. http://dx.doi.org/10.1038/nmeth. 3415 (PMID: 26005811).

Pascual, O., Casper, K.B., Kubera, C., Zhang, J., Revilla-Sanchez, R., Sul, J.Y., Takano, H., Moss, S.J., McCarthy, K., Haydon, P.G., 2005. Astrocytic purinergic signaling coordinates synaptic networks. Science 310, 113-116. http://dx.doi.org/10.1126/science. 1116916 ([pii] 310/5745/113 [pii] PMID: 16210541).

Perea, G., Navarrete, M., Araque, A., 2009. Tripartite synapses: astrocytes process and control synaptic information. Trends Neurosci. 32, 421-431.

Pfrieger, F.W., 2009. Roles of glial cells in synapse development. Cell. Mol. Life Sci. 66, 2037-2047. http://dx.doi.org/10.1007/s00018-009-0005-7 (PMID: 19308323).

Pfrieger, F.W., Barres, B.A., 1997. Synaptic efficacy enhanced by glial cells in vitro. Science 277, 1684-1687 (PMID: 9287225).

Portelius, E., Andreasson, U., Ringman, J.M., Buerger, K., Daborg, J., Buchhave, P.., Hansson, O., Harmsen, A., Gustavsson, M.K., Hanse, E., Galasko, D., Hampel, H., Blennow, K. Zetterberg, H., 2010. Distinct cerebrospinal fluid amyloid beta peptide signatures in sporadic and PSEN1 A431E-associated familial Alzheimer's disease. Mol. Neurodegener. 5, 2. http://dx.doi.org/10.1186/1750-1326-5-2 (PMID: 20145736).

Pouya, A., Satarian, L., Kiani, S., Javan, M., Baharvand, H., 2011. Human induced pluripotent stem cells differentiation into oligodendrocyte progenitors and transplantation in a rat model of optic chiasm demyelination. PLoS One 6, e27925. http://dx.doi.org/10. 1371/journal.pone.0027925 (PMID: 22125639).

Puschmann, T.B., Zanden, C., De Pablo, Y., Kirchhoff, F., Pekna, M., Liu, J., Pekny, M., 2013. Bioactive 3D cell culture system minimizes cellular stress and maintains the in vivolike morphological complexity of astroglial cells. Glia 61, 432-440. http://dx.doi.org/ 10.1002/glia.22446 (PMID: 23292921).

Qi, L.S., Larson, M.H., Gilbert, L.A., Doudna, J.A., Weissman, J.S., Arkin, A.P., Lim, W.A., 2013. Repurposing CRISPR as an RNA- $\gamma$ uided platform for sequence-specific control of gene expression. Cell 152, 1173-1183.

Ran, F.A., Hsu, P.D., Wright, J., Agarwala, V., Scott, D.A., Zhang, F., 2013. Genome engineering using the CRISPR-Cas9 system. Nat. Protoc. 8, 2281-2308. http://dx.doi.org/10. 1038/nprot.2013.143 (PMID: 24157548).

Robakis, N.K., Wisniewski, H.M., Jenkins, E.C., Devine-Gage, E.A., Houck, G.E., Yao, X.L. Ramakrishna, N., Wolfe, G., Silverman, W.P., Brown, W.T., 1987. Chromosome 21q21 sublocalisation of gene encoding beta-amyloid peptide in cerebral vessels and neuritic (senile) plaques of people with Alzheimer disease and Down syndrome. Lancet 1, 384-385 (PMID: 2880184).

Robinson, S.R., 2001. Changes in the cellular distribution of glutamine synthetase in Alzheimer's disease. J. Neurosci. Res. 66, 972-980 (PMID: 11746426).

Rogaev, E.I., Sherrington, R., Rogaeva, E.A., Levesque, G., Ikeda, M., Llang, Y., Chi, H., Lin, C., Holman, K., Tsuda, T., Mar, L., Sorbi, S., Nacmias, B., Piacentini, S., Amaduccl, L. Chumakov, I., Cohen, D., Lannfelt, L., St George-Hyslop, P.H., 1995. Familia Alzheimer's disease in kindreds with missense mutations in a gene on chromosome 1 related to the Alzheimer's disease type 3 gene. Nature 376, 775-778.

Roth, A.D., Ramirez, G., Alarcon, R., Von Bernhardi, R., 2005. Oligodendrocytes damage in Alzheimer's disease: beta amyloid toxicity and inflammation. Biol. Res. 38, 381-387 (PMID: 16579521).

Rouhani, F., Kumasaka, N., de Brito, M.C., Bradley, A., Vallier, L., Gaffney, D., 2014. Genetic background drives transcriptional variation in human induced pluripotent stem cells. PLoS Genet. 10, e1004432. http://dx.doi.org/10.1371/journal.pgen.1004432 (PMID: 24901476)

Rumble, B., Retallack, R., Hilbich, C., Simms, G., Multhaup, G., Martins, R., Hockey, A Montgomery, P., Beyreuther, K., Masters, C.L., 1989. Amyloid A4 protein and its precursor in Down's syndrome and Alzheimer's disease. N. Engl. J. Med. 320, 1446-1452 (doi: papers://3039E21D-04C9-4FF4-AF76-9D1A38439DE0/Paper/p1254).

Ryan, S.D., Dolatabadi, N., Chan, S.F., Zhang, X., Akhtar, M.W., Parker, J., Soldner, F., Sunico, C.R., Nagar, S., Talantova, M., Lee, B., Lopez, K., Nutter, A., Shan, B., Molokanova, E., Zhang, Y., Han, X., Nakamura, T., Masliah, E., Yates 3rd, J.R., Nakanishi, N., Andreyev, A.Y., Okamoto, S., Jaenisch, R., Ambasudhan, R., Lipton, S.A., 2013. Isogenic human iPSC Parkinson's model shows nitrosative stress-induced dysfunction in MEF2PGC1alpha transcription. Cell 155, 1351-1364. http://dx.doi.org/10.1016/j.cell.2013. 11.009 (PMID: 24290359).

Sahin, E., DePinho, R.A., 2010. Linking functional decline of telomeres, mitochondria and stem cells during ageing. Nature 464, 520-528.

Salloway, S., Sperling, R., Fox, N.C., Blennow, K., Klunk, W., Raskind, M., Sabbagh, M., Honig, L.S., Porsteinsson, A.P., Ferris, S., Reichert, M., Ketter, N., Nejadnik, B., Guenzler, V., Miloslavsky, M., Wang, D., Lu, Y., Lull, J., Tudor, I.C., Liu, E., Grundman M., Yuen, E., Black, R., Brashear, H.R., Bapineuzumab and Clinical Trial, I, 2014. Two phase 3 trials of bapineuzumab in mild-to-moderate Alzheimer's disease. $\mathrm{N}$. Engl. J. Med. 370, 322-333. http://dx.doi.org/10.1056/NEJMoa1304839 (PMID: 24450891).
Samuel, R., Daheron, L., Liao, S., Vardam, T., Kamoun, W.S., Batista, A., Buecker, C., Schafer, R., Han, X., Au, P., Scadden, D.T., Duda, D.G., Fukumura, D., Jain, R.K., 2013. Generation of functionally competent and durable engineered blood vessels from human induced pluripotent stem cells. Proc. Natl. Acad. Sci. U. S. A. 110, 12774-12779. http://dx.doi.org/10.1073/pnas.1310675110 (PMID: 23861493).

Sander, J.D., Joung, J.K., 2014. CRISPR-Cas systems for editing, regulating and targeting genomes. Nat. Biotechnol. 32, 347-355. http://dx.doi.org/10.1038/nbt.2842 (PMID: 24584096)

Sandoe, J., Eggan, K., 2013. Opportunities and challenges of pluripotent stem cell neurodegenerative disease models. Nat. Neurosci. 16, 780-789. http://dx.doi.org/10.1038/nn. 3425 (PMID: 23799470)

Schellenberg, G.D., Payami, H., Wijsman, E.M., Orr, H.T., Goddard, K.A., Anderson, L., Nemens, E., White, J.A., Alonso, M.E., Ball, M.J., et al., 1993. Chromosome 14 and late-onset familial Alzheimer disease (FAD). Am. J. Hum. Genet. 53, 619-628 (PMID: 8352272)

Schwartz, M.P., Hou, Z., Propson, N.E., Zhang, J., Engstrom, C.J., Costa, V.S., Jiang, P., Nguyen, B.K., Bolin, J.M., Daly, W., Wang, Y., Stewart, R., Page, C.D., Murphy, W.L., Thomson, J.A., 2015. Human pluripotent stem cell-derived neural constructs for predicting neural toxicity. Proc. Natl. Acad. Sci. U. S. A. 112, 12516-12521. http://dx.doi.org/10. 1073/pnas.1516645112 (PMID: 26392547)

Selvaraj, V., Jiang, P., Chechneva, O., Lo, U.G., Deng, W., 2012. Differentiating human stem cells into neurons and glial cells for neural repair. Front. Biosci. 17, 65-89 (PMID: 22201733)

Sergent-Tanguy, S., Chagneau, C., Neveu, I., Naveilhan, P., 2003. Fluorescent activated cell sorting (FACS): a rapid and reliable method to estimate the number of neurons in a mixed population. J. Neurosci. Methods 129, 73-79. http://dxdoi.org/10.1016/ 50165-0270(03)00210-3 (PMID: 12951234).

Shalem, O., Sanjana, N.E., Hartenian, E., Shi, X., Scott, D.A., Mikkelsen, T.S., Heckl, D., Ebert, B.L., Root, D.E., Doench, J.G., Zhang, F., 2014. Genome-scale CRISPR-Cas9 knockout screening in human cells. Science 343, 84-87. http://dx.doi.org/10.1126/science. 1247005 (PMID: 24336571).

Shi, Y., Kirwan, P., Livesey, F.J., 2012a. Directed differentiation of human pluripotent stem cells to cerebral cortex neurons and neural networks. Nat. Protoc. 7, 1836-1846. http://dx.doi.org/10.1038/nprot.2012.116 (PMID: 22976355).

Shi, Y., Kirwan, P., Smith, J., MacLean, G., Orkin, S.H., Livesey, F.J., 2012b. A human stem cell model of early Alzheimer's disease pathology in Down syndrome. Sci. Transl. Med. 4 , 124ra29. http://dx.doi.org/10.1126/scitranslmed.3003771 (PMID: 22344463).

Shi, Y., Kirwan, P., Smith, J., Robinson, H.P., Livesey, F.J., 2012c. Human cerebral cortex development from pluripotent stem cells to functional excitatory synapses. Nat. Neurosci. 15, 477-486. http://dx.doi.org/10.1038/nn.3041 (s1, PMID: 22306606).

Shigetomi, E., Bushong, E.A., Haustein, M.D., Tong, X., Jackson-Weaver, O., Kracun, S., Xu, J., Sofroniew, M.V., Ellisman, M.H., Khakh, B.S., 2013. Imaging calcium microdomains within entire astrocyte territories and endfeet with GCaMPs expressed using adeno-associated viruses. J. Gen. Physiol. 141, 633-647. http://dx.doi.org/10.1085/ jgp.201210949 (PMID: 23589582)

Shimamoto, A., Yokote, K., Tahara, H., 2015. Werner syndrome-specific induced pluripotent stem cells: recovery of telomere function by reprogramming. Front. Genet. 6, 10. http://dx.doi.org/10.3389/fgene.2015.00010 (PMID: 25688260).

Siegert, S., Cabuy, E., Scherf, B.G., Kohler, H., Panda, S., Le, Y.Z., Fehling, H.J., Gaidatzis, D., Stadler, M.B., Roska, B., 2012. Transcriptional code and disease map for adult retinal cell types. Nat. Neurosci. 15, 487-495. http://dx.doi.org/10.1038/nn.3032 (S1-2, PMID: 22267162).

Slaymaker, I.M., Gao, L., Zetsche, B., Scott, D.A., Yan, W.X., Zhang, F., 2015. Rationally engineered Cas9 nucleases with improved specificity. Science.

Smith, I., Silveirinha, V., Stein, J.L., de la Torre-Ubieta, L., Farrimond, J.A., Williamson, E.M., Whalley, B.J., 2015. Human neural stem cell-derived cultures in three-dimensional substrates form spontaneously functional neuronal networks. J. Tissue Eng. Regen. Med. http://dx.doi.org/10.1002/term.2001 (PMID: 25712225).

Soldner, F., Jaenisch, R., 2012. iPSC disease modeling. Science 338, 1155-1156,

Soldner, F., Hockemeyer, D., Beard, C., Gao, Q., Bell, G.W., Cook, E.G., Hargus, G., Blak, A., Cooper, O., Mitalipova, M., Isacson, O., Jaenisch, R., 2009. Parkinson's disease patient-derived induced pluripotent stem cells free of viral reprogramming factors. Cell 136, 964-977. http://dx.doi.org/10.1016/j.cell.2009.02.013 ([pii]S00928674(09)00151-2 [pii] PMID: 19269371).

Soldner, F., Laganière, J., Cheng, A.W., Hockemeyer, D., Gao, Q., Alagappan, R., Khurana, V., Golbe, L.I., Myers, R.H., Lindquist, S., Zhang, L., Guschin, D., Fong, L.K., Vu, B.J., Meng, X., Urnov, F.D., Rebar, E.J., Gregory, P.D., Zhang, H.S., Jaenisch, R., 2011. Generation of isogenic pluripotent stem cells differing exclusively at two early onset Parkinson point mutations. Cell 146, 318-331. http://dx.doi.org/10.1016/j.cell.2011.06.019.

Spillantini, M.G., Murrell, J.R., Goedert, M., Farlow, M.R., Klug, A., Ghetti, B., 1998. Mutation in the tau gene in familial multiple system tauopathy with presenile dementia. Proc. Natl. Acad. Sci. U. S. A. 95, 7737-7741 (PMID: 9636220)

Spittaels, K., Van Den Haute, C., Van Dorpe, J., Bruynseels, K., Vandezande, K., Laenen, I., Geerts, H., Mercken, M., Sciot, R. Van Lommel, A., Loos, R., Van Leuven, F. 1999. Prominent axonopathy in the brain and spinal cord of transgenic mice overexpressing four-repeat human tau protein. Am. J. Pathol. 155, 2153-2165.

Sproul, A.A. Jacob, S., Pre, D. Kim, S.H. Nestor, M.W., Navarro-Sobrino, M. Santa-Maria, I., Zimmer, M., Aubry, S., Steele, J.W., Kahler, D.J., Dranovsky, A., Arancio, O., Crary, J.F., Gandy, S., Noggle, S.A., 2014. Characterization and molecular profiling of PSEN1 familial Alzheimer's disease iPSC-derived neural progenitors. PLoS One 9, e84547. http:// dx.doi.org/10.1371/journal.pone.0084547 (PMID: 24416243)

St George-Hyslop, P.H., Tanzi, R.E., Polinsky, R.J., Haines, J.L., Nee, L., Watkins, P.C., Myers, R.H., Feldman, R.G., Pollen, D., Drachman, D., et al., 1987. The genetic defect causing familial Alzheimer's disease maps on chromosome 21. Science 235, 885-890 (PMID: 2880399). 
Streit, W.J., Xue, Q.S., 2010. The brain's aging immune system. Aging Dis. 1, 254-261 (PMID: 21833348)

Streit, W.J., Braak, H., Xue, Q.S., Bechmann, I., 2009. Dystrophic (senescent) rather than activated microglial cells are associated with tau pathology and likely precede neurodegeneration in Alzheimer's disease. Acta Neuropathol. 118, 475-485. http://dx.doi. org/10.1007/s00401-009-0556-6 (PMID: 19513731).

Sugaya, K., Reeves, M., McKinney, M., 1997. Topographic associations between DNA fragmentation and Alzheimer's disease neuropathology in the hippocampus. Neurochem. Int. 31, 275-281. http://dx.doi.org/10.1016/S0197-0186(96)00158-1 (PMID: 9220460).

Sun, W., McConnell, E., Pare, J.F., Xu, Q., Chen, M., Peng, W., Lovatt, D., Han, X., Smith, Y., Nedergaard, M., 2013. Glutamate-dependent neuroglial calcium signaling differs between young and adult brain. Science 339, 197-200. http://dx.doi.org/10.1126/ science.1226740 (PMID: 23307741).

Swistowski, A., Peng, J., Liu, Q., Mali, P., Rao, M.S., Cheng, L., Zeng, X., 2010. Efficient generation of functional dopaminergic neurons from human induced pluripotent stem cells under defined conditions. Stem Cells 28, 1893-1904. http://dx.doi.org/10. 1002/stem.499 (PMID: 20715183).

Tabata, H., 2015. Diverse subtypes of astrocytes and their development during corticogenesis. Front. Neurosci. 9, 114. http://dx.doi.org/10.3389/fnins.2015.00114 (PMID: 25904839).

Tada, M., Takahama, Y., Abe, K., Nakatsuji, N., Tada, T., 2001. Nuclear reprogramming of somatic cells by in vitro hybridization with ES cells. Curr. Biol. 11, 1553-1558. http://dx. doi.org/10.1016/s0960-9822(01)00459-6 (PMID: 11591326).

Takahashi, K., Yamanaka, S., 2006. Induction of pluripotent stem cells from mouse embryonic and adult fibroblast cultures by defined factors. Cell 126, 663-676.

Takahashi, K., Tanabe, K., Ohnuki, M., Narita, M., Ichisaka, T., Tomoda, K., Yamanaka, S., 2007. Induction of pluripotent stem cells from adult human fibroblasts by defined factors. Cell 131, 861-872. http://dx.doi.org/10.1016/j.cell.2007.11.019.[pii]S00928674(07)01471-7 ([pii] PMID: 18035408).

Takebe, T., Sekine, K., Enomura, M., Koike, H., Kimura, M., Ogaeri, T., Zhang, R.R., Ueno, Y., Zheng, Y.W., Koike, N., Aoyama, S., Adachi, Y., Taniguchi, H., 2013. Vascularized and functional human liver from an iPSC-derived organ bud transplant. Nature 499 481-484. http://dx.doi.org/10.1038/nature12271 (PMID: 23823721).

Tanzi, R.E., Gusella, J.F., Watkins, P.C., Bruns, G.A., St George-Hyslop, P., Van Keuren, M.L., Patterson, D., Pagan, S., Kurnit, D.M., Neve, R.L., 1987. Amyloid beta protein gene: cDNA, mRNA distribution, and genetic linkage near the Alzheimer locus. Science 235, 880-884 (PMID: 2949367).

Telias, M., Ben-Yosef, D., 2014. Modeling neurodevelopmental disorders using human pluripotent stem cells. Stem Cell Rev. 10, 494-511. http://dx.doi.org/10.1007/ s12015-014-9507-2 (PMID: 24728983).

Thomson, J.A., Itskovitz-Eldor, J., Shapiro, S.S., Waknitz, M.A., Swiergiel, J.J., Marshall, V.S., Jones, J.M., 1998. Embryonic stem cell lines derived from human blastocysts. Science 282, 1145-1147 (PMID: 9804556).

Tilleux, S., Hermans, E., 2007. Neuroinflammation and regulation of glial glutamate uptake in neurological disorders. J. Neurosci. Res. 85, 2059-2070. http://dx.doi.org/10. 1002/jnr.21325 (PMID: 17497670).

Tonnesen, J., Katona, G., Rozsa, B., Nagerl, U.V., 2014. Spine neck plasticity regulates compartmentalization of synapses. Nat. Neurosci. 17, 678-685. http://dx.doi.org/10. 1038/nn.3682 (PMID: 24657968).

Tsai, S.Q., Zheng, Z., Nguyen, N.T., Liebers, M., Topkar, V.V., Thapar, V., Wyvekens, N., Khayter, C., Iafrate, A.J., Le, L.P., Aryee, M.J., Joung, J.K., 2015. GUIDE-seq enables genome-wide profiling of off-target cleavage by CRISPR-Cas nucleases. Nat. Biotechnol. 33, 187-197. http://dx.doi.org/10.1038/nbt.3117 (PMID: 25513782).

Tsuchiya, T., Park, K.C., Toyonaga, S., Yamada, S.M., Nakabayashi, H., Nakai, E., Ikawa, N., Furuya, M., Tominaga, A., Shimizu, K., 2005. Characterization of microglia induced from mouse embryonic stem cells and their migration into the brain parenchyma. J. Neuroimmunol. 160, 210-218. http://dx.doi.org/10.1016/j.jneuroim.2004.10.025 (PMID: 15710475).

Ullian, E.M., Harris, B.T., Wu, A., Chan, J.R., Barres, B.A., 2004. Schwann cells and astrocytes induce synapse formation by spinal motor neurons in culture. Mol. Cell. Neurosci. 25, 241-251. http://dx.doi.org/10.1016/j.mcn.2003.10.011 (PMID: 15019941).

Urnov, F.D., Rebar, E.J., Holmes, M.C., Zhang, H.S., Gregory, P.D., 2010. Genome editing with engineered zinc finger nucleases. Nat. Rev. Genet. 11, 636-646. http://dx.doi. org/10.1038/nrg2842 (PMID: 20717154)

Verwer, R.W., Dubelaar, E.J., Hermens, W.T., Swaab, D.F., 2002. Tissue cultures from adult human postmortem subcortical brain areas. J. Cell. Mol. Med. 6, 429-432. http://dx. doi.org/10.1111/j.1582-4934.2002.tb00522.x (PMID: 12417060).

Wang, L., Meece, K., Williams, D.J., Lo, K.A., Zimmer, M., Heinrich, G., Martin Carli, J., Leduc, C.A., Sun, L., Zeltser, L.M., Freeby, M., Goland, R., Tsang, S.H., Wardlaw, S.L., Egli, D. Leibel, R.L., 2015. Differentiation of hypothalamic-like neurons from human pluripotent stem cells. J. Clin. Invest. 125, 796-808. http://dx.doi.org/10.1172/JCI79220 (PMID: 25555215)

Wang, S., Bates, J., Li, X., Schanz, S., Chandler-Militello, D., Levine, C., Maherali, N., Studer, L., Hochedlinger, K., Windrem, M., Goldman, S.A., 2013. Human iPSC-derived oligodendrocyte progenitor cells can myelinate and rescue a mouse model of congenital hypomyelination. Cell Stem Cell 12, 252-264. http://dx.doi.org/10.1016/j.stem.2012. 12.002 (PMID: 23395447).

Wang, T., Wei, J.J., Sabatini, D.M., Lander, E.S., 2014. Genetic screens in human cells using the CRISPR-Cas9 system. Science 343, 80-84. http://dx.doi.org/10.1126/science. 1246981 (PMID: 24336569).

Wang, W.Y., Pan, L., Su, S.C., Quinn, E.J., Sasaki, M., Jimenez, J.C., Mackenzie, I.R., Huang, E.J., Tsai, L.H., 2013. Interaction of FUS and HDAC1 regulates DNA damage response and repair in neurons. Nat. Neurosci. 16, 1383-1391. http://dx.doi.org/10.1038/nn.3514 (PMID: 24036913).
Webster, S.J., Bachstetter, A.D., Nelson, P.T., Schmitt, F.A., Van Eldik, L.J., 2014. Using mice to model Alzheimer's dementia: an overview of the clinical disease and the preclinical behavioral changes in 10 mouse models. Front. Genet. 5, 88-88. http://dx.doi.org/ 10.3389/fgene.2014.00088 (PMID: MEDLINE:24795750).

Weick, J.P., Held, D.L., Bonadurer 3rd, G.F., Doers, M.E., Liu, Y., Maguire, C., Clark, A Knackert, J.A., Molinarolo, K., Musser, M., Yao, L., Yin, Y., Lu, J., Zhang, X., Zhang, S.C., Bhattacharyya, A., 2013. Deficits in human trisomy 21 iPSCs and neurons. Proc. Natl. Acad. Sci. U. S. A. 110, 9962-9967. http://dx.doi.org/10.1073/pnas.1216575110 (PMID: 23716668).

Wen, J.-Y., Wei, C.-Y., Shah, K., Wong, J., Wang, C., Chen, H.-S.V., 2015. Maturation-based model of arrhythmogenic right ventricular dysplasia using patient-specific induced pluripotent stem cells. Circ. J. http://dx.doi.org/10.1253/circj.CJ-15-0363.

Wen, Z., Nguyen, H.N., Guo, Z., Lalli, M.A., Wang, X., Su, Y., Kim, N.-S., Yoon, K.-J., Shin, J., Zhang, C., Makri, G., Nauen, D., Yu, H., Guzman, E., Chiang, C.-H., Yoritomo, N., Kaibuchi, K., Zou, J., Christian, K.M., Cheng, L., Ross, C.A., Margolis, R.L., Chen, G. Kosik, K.S., Song, H., Ming, G.-l., 2014. Synaptic dysregulation in a human iPS cell model of mental disorders. Nature 515, 414-418. http://dx.doi.org/10.1038/ nature13716 (PMID: MEDLINE:25132547).

Wilmut, I., Schnieke, A.E., McWhir, J., Kind, A.J., Campbell, K.H., 1997. Viable offspring derived from fetal and adult mammalian cells. Nature 385, 810-813. http://dx.doi. org/10.1038/385810a0 (PMID: 9039911).

Wolozin, B., 2012. Statins and therapy of Alzheimer's disease: questions of efficacy versus trial design. Alzheimers Res. Ther. 4, 3. http://dx.doi.org/10.1186/alzrt101 (PMID: 22264400).

Woodruff, G., Young, J.E., Martinez, F.J., Buen, F., Gore, A., Kinaga, J., Li, Z., Yuan, S.H., Zhang, K. Goldstein, L.S., 2013. The presenilin-1 DeltaE9 mutation results in reduced gammasecretase activity, but not total loss of PS1 function, in isogenic human stem cells. Cell Rep. 5, 974-985. http://dx.doi.org/10.1016/j.celrep.2013.10.018 (PMID: 24239350).

Woods, Y.L., Cohen, P., Becker, W., Jakes, R., Goedert, M., Wang, X., Proud, C.G., 2001. The kinase DYRK phosphorylates protein-synthesis initiation factor eIF2Bepsilon at Ser539 and the microtubule-associated protein tau at Thr212: potential role for DYRK as a glycogen synthase kinase 3-priming kinase. Biochem. J. 355, 609-615 (PMID: 11311121).

Wren, M.C., Zhao, J., Liu, C.C., Murray, M.E., Atagi, Y., Davis, M.D., Fu, Y., Okano, H.J., Ogaki, K., Strongosky, A.J., Tacik, P., Rademakers, R., Ross, O.A., Dickson, D.W., Wszolek, Z.K. Kanekiyo, T., Bu, G., 2015. Frontotemporal dementia-associated N279K tau mutant disrupts subcellular vesicle trafficking and induces cellular stress in iPSC-derived neural stem cells. Mol. Neurodegener. 10, 46. http://dx.doi.org/10.1186/s13024015-0042-7 (PMID: 26373282).

Wunderlich, P., Glebov, K., Kemmerling, N., Tien, N.T., Neumann, H., Walter, J., 2013. Sequential proteolytic processing of the triggering receptor expressed on myeloid cells-2 (TREM2) by ectodomain shedding and gamma-secretase dependent intramembranous cleavage. J. Biol. Chem. http://dx.doi.org/10.1074/jbc.M113. 517540 (PMID: 24078628).

Xie, L., Kang, H., Xu, Q., Chen, M.J., Liao, Y., Thiyagarajan, M., O'Donnell, J., Christensen, D.J., Nicholson, C., Iliff, J.J., Takano, T., Deane, R., Nedergaard, M., 2013. Sleep drives metabolite clearance from the adult brain. Science 342, 373-377. http://dx.doi.org/10.1126/ science.1241224 (PMID: 24136970).

Xu, X., Lei, Y., Luo, J., Wang, J., Zhang, S., Yang, X.J., Sun, M., Nuwaysir, E., Fan, G., Zhao, J. Lei, L., Zhong, Z., 2013. Prevention of beta-amyloid induced toxicity in human iPS cellderived neurons by inhibition of cyclin-dependent kinases and associated cell cycle events. Stem Cell Res. 10, 213-227. http://dx.doi.org/10.1016/j.scr.2012.11.005 (PMID: 23305945).

Yagi, T., Ito, D., Okada, Y., Akamatsu, W., Nihei, Y., Yoshizaki, T., Yamanaka, S., Okano, H. Suzuki, N., 2011. Modeling familial Alzheimer's disease with induced pluripotent stem cells. Hum. Mol. Genet. 20, 4530-4539. http://dx.doi.org/10.1093/hmg/ddr394 (PMID: 21900357).

Yahata, N., Asai, M., Kitaoka, S., Takahashi, K., Asaka, I., Hioki, H., Kaneko, T., Maruyama, K. Saido, T.C., Nakahata, T., Asada, T., Yamanaka, S., Iwata, N., Inoue, H., 2011. Anti-Abeta drug screening platform using human iPS cell-derived neurons for the treatment of Alzheimer's disease. PLoS One 6, e25788. http://dx.doi.org/10.1371/journal.pone. 0025788 (PMID: 21984949).

Yang, F., Sun, X., Beech, W., Teter, B., Wu, S., Sigel, J., Vinters, H.V., Frautschy, S.A., Cole G.M., 1998. Antibody to caspase-cleaved actin detects apoptosis in differentiated neuroblastoma and plaque-associated neurons and microglia in Alzheimer's disease. Am. J. Pathol. 152, 379-389 (PMID: 9466564).

Yoshida, M., Kitaoka, S., Egawa, N., Yamane, M., Ikeda, R., Tsukita, K., Amano, N. Watanabe, A., Morimoto, M., Takahashi, J., Hosoi, H., Nakahata, T., Inoue, H., Saito, M.K., 2015. Modeling the early phenotype at the neuromuscular junction of spinal muscular atrophy using patient-derived iPSCs. Stem Cell Rep. 4, 561-568. http://dx. doi.org/10.1016/j.stemcr.2015.02.010 (PMID: 25801509).

Yoshimizu, T., Pan, J.Q., Mungenast, A.E., Madison, J.M., Su, S., Ketterman, J., Ongur, D. McPhie, D., Cohen, B., Perlis, R., Tsai, L.H., 2015. Functional implications of a psychiatric risk variant within CACNA1C in induced human neurons. Mol. Psychiatry 20, 284 http://dx.doi.org/10.1038/mp.2014.181 (PMID: 25623946).

Youmans, K.L., Tai, L.M., Nwabuisi-Heath, E., Jungbauer, L., Kanekiyo, T., Gan, M., Kim, J. Eimer, W.A., Estus, S., Rebeck, G.W., Weeber, E.J., Bu, G., Yu, C., LaDu, M.J., 2012 APOE4-specific changes in $A \beta$ accumulation in a new transgenic mouse model of alzheimer disease. J. Biol. Chem. 287, 41774-41786.

Young, J.E., Boulanger-Weill, J., Williams, D.A., Woodruff, G., Buen, F., Revilla, A.C., Herrera, C., Israel, M.A., Yuan, S.H., Edland, S.D., Goldstein, L.S., 2015. Elucidating molecular phenotypes caused by the SORL1 Alzheimer's disease genetic risk factor using human induced pluripotent stem cells. Cell Stem Cell 16, 373-385. http://dx.doi. org/10.1016/j.stem.2015.02.004 (PMID: 25772071).

Yusa, K., Rashid, S.T., Strick-Marchand, H., Varela, I., Liu, P.Q., Paschon, D.E., Miranda, E., Ordonez, A., Hannan, N.R., Rouhani, F.J., Darche, S., Alexander, G., Marciniak, S.J., 
Fusaki, N. Hasegawa, M.. Holmes, M.C., Di Santo, J.P., Lomas, D.A., Bradley, A., Vallier, L., 2011. Targeted gene correction of alpha1-antitrypsin deficiency in induced pluripotent stem cells. Nature 478, 391-394. http://dx.doi.org/10.1038/nature10424 (PMID: 21993621).

Zeng, H., Guo, M., Martins-Taylor, K., Wang, X., Zhang, Z., Park, J.W., Zhan, S., Kronenberg M.S., Lichtler, A., Liu, H.X., Chen, F.P., Yue, L., Li, X.J., Xu, R.H., 2010. Specification of region-specific neurons including forebrain glutamatergic neurons from human induced pluripotent stem cells. PLoS One 5, e11853. http://dx.doi.org/10.1371/ journal.pone.0011853 (PMID: 20686615).

Zhang, B., Gaiteri, C., Bodea, L.G., Wang, Z., McElwee, J., Podtelezhnikov, A.A., Zhang, C., Xie, T., Tran, L., Dobrin, R., Fluder, E., Clurman, B., Melquist, S., Narayanan, M., Suver, C., Shah, H., Mahajan, M., Gillis, T., Mysore, J., MacDonald, M.E., Lamb, J.R., Bennett, D.A., Molony, C., Stone, D.J., Gudnason, V., Myers, A.J., Schadt, E.E., Neumann, H., Zhu, J., Emilsson, V., 2013. Integrated systems approach identifies genetic nodes and networks in late-onset Alzheimer's disease. Cell 153, 707-720. http://dx.doi. org/10.1016/j.cell.2013.03.030 (PMID: 23622250).

Zhang, D., Pekkanen-Mattila, M., Shahsavani, M., Falk, A., Teixeira, A.I., Herland, A., 2014. A 3D Alzheimer's disease culture model and the induction of P21-activated kinase mediated sensing in iPSC derived neurons. Biomaterials 35, 1420-1428. http://dx.doi. org/10.1016/j.biomaterials.2013.11.028 (PMID: 24290439).

Zhang, F., Wang, L.P., Boyden, E.S., Deisseroth, K., 2006. Channelrhodopsin-2 and optical control of excitable cells. Nat. Methods 3, 785-792. http://dx.doi.org/10.1038 nmeth936 (nmeth936 [pii], PMID: 16990810).

Zhang, F., Wen, Y., Guo, X., 2014. CRISPR/Cas9 for genome editing: progress, implications and challenges. Hum. Mol. Genet. 23, R40-R46. http://dx.doi.org/10.1093/hmg/ ddu125 (PMID: 24651067).

Zhang, N., An, M.C., Montoro, D., Ellerby, L.M., 2010. Characterization of human huntington's disease cell model from induced pluripotent stem cells. PLoS Curr. 2, RRN1193. http://dx.doi.org/10.1371/currents.RRN1193 (PMID: 21037797).
Zhang, Q., Yu, J.T., Zhu, O.X., Zhang, W., Wu, Z.C., Miao, D., Tan, L., 2010. Complement receptor 1 polymorphisms and risk of late-onset Alzheimer's disease. Brain Res. 1348, 216-221. http://dx.doi.org/10.1016/j.brainres.2010.06.018 (PMID: 20558149).

Zhang, Y., Chen, K., Sloan, S.A., Bennett, M.L., Scholze, A.R., O'Keeffe, S., Phatnani, H.P., Guarnieri, P., Caneda, C., Ruderisch, N., Deng, S., Liddelow, S.A., Zhang, C., Daneman, R., Maniatis, T., Barres, B.A., Wu, J.Q., 2014. An RNA-sequencing transcriptome and splicing database of glia, neurons, and vascular cells of the cerebral cortex. J. Neurosci. 34, 11929-11947. http://dx.doi.org/10.1523/JNEUROSCI.1860-14.2014 (PMID: 25186741)

Zhang, Y., Pak, C., Han, Y., Ahlenius, H., Zhang, Z., Chanda, S., Marro, S., Patzke, C., Acuna, C., Covy, J., Xu, W., Yang, N., Danko, T., Chen, L., Wernig, M., Südhof, T.C., 2013. Rapid single-step induction of functional neurons from human pluripotent stem cells. Neuron 78, 785-798. http://dx.doi.org/10.1016/j.neuron.2013.05.029.

Zhou, T., Benda, C., Dunzinger, S., Huang, Y., Ho, J.C., Yang, J., Wang, Y., Zhang, Y., Zhuang, Q, Li, Y, Bao, X. Tse, H.F, Grillari, J, Grillari-Voglauer, R, Pei, D. Esteban, M.A, 2012. Generation of human induced pluripotent stem cells from urine samples. Nat. Protoc. 7, 2080-2089. http://dx.doi.org/10.1038/nprot.2012.115 (PMID: 23138349).

Zhu, Z., Gonzalez, F., Huangfu, D., 2014. The iCRISPR platform for rapid genome editing in human pluripotent stem cells. Methods Enzymol. 546, 215-250. http://dx.doi.org/10. 1016/b978-0-12-801185-0.00011-8 (PMID: MEDLINE:25398343).

Zou, J., Maeder, M.L., Mali, P., Pruett-Miller, S.M., Thibodeau-Beganny, S., Chou, B.K., Chen, G., Ye, Z., Park, I.H., Daley, G.O., Porteus, M.H., Joung, J.K., Cheng, L., 2009. Gene targeting of a disease-related gene in human induced pluripotent stem and embryonic stem cells. Cell Stem Cell 5, 97-110. http://dx.doi.org/10.1016/j.stem.2009.05.023 (PMID: 19540188). 